Historic, Archive Document

Do not assume content reflects current

scientific knowledge, policies, or practices. 


\section{Parcel Post Shipments}

We ship by parcel post to a:z rostoffice in the United States, Alaska, Cuba, Canacia, the Philippines, Porto Rico, the Canal Zone, the Hawaiian Islands, and prepay the postage at postpaid prices as quoted in this catalog; or, if you prefer it, will ship by express, charges prepaic.

"By express" means you pay the freight. Beyond the Thirc zone it is cheaper to ship by express.

Prices of field seeds, fertilizers and poultry foods fluctuate and are subject to market changes. Price changes free for the asking.

\section{Notes About Parcel Post}

Weight limit to 1st, $2 d$ and $3 d$ Zones, 70 lbs.; in other Bulk limit to all zones, 84 inches.

Poisons cannot be sent by parcel post.

Iiquids and goods packed in glass should be sent by Parcels Post Rates

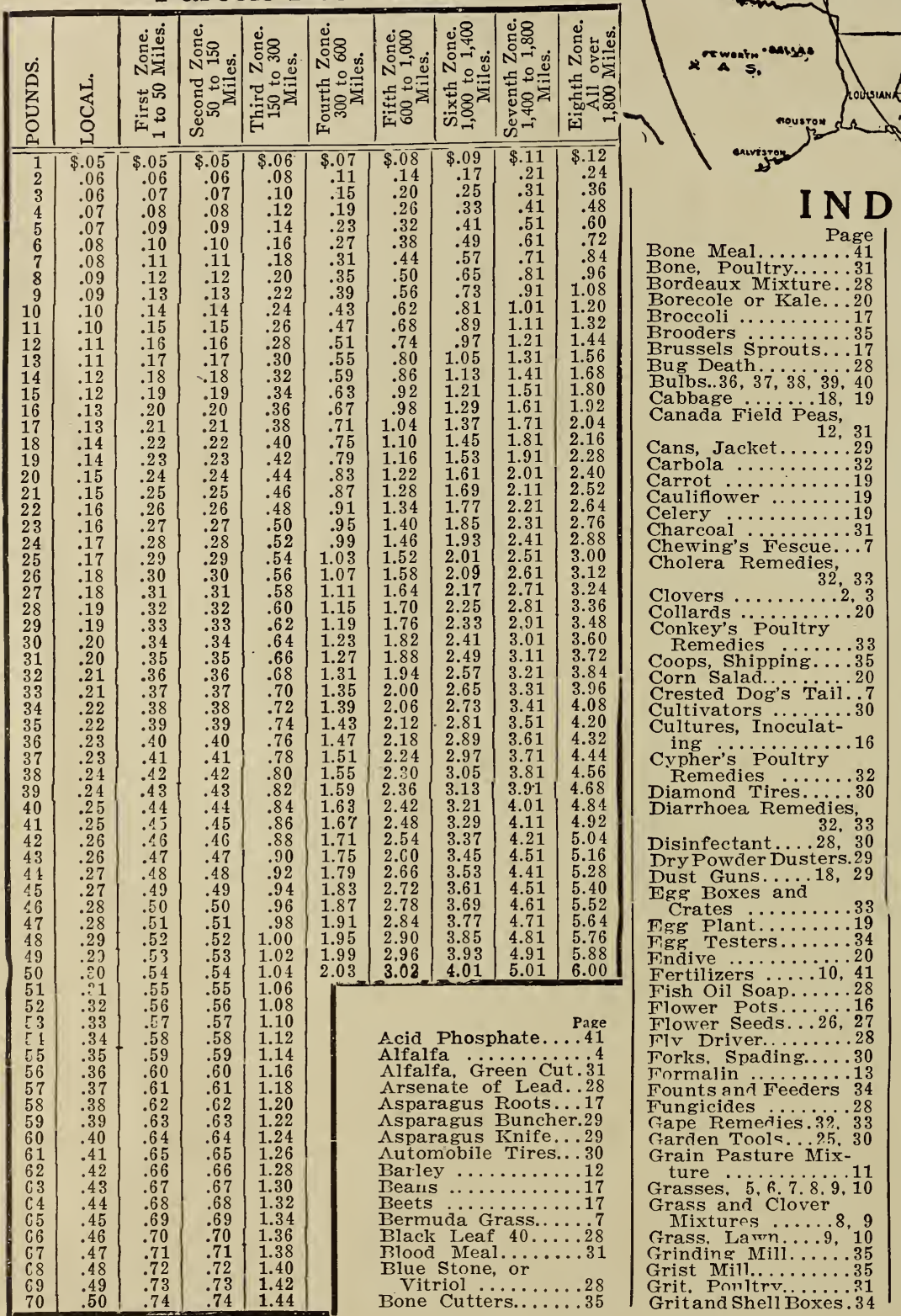

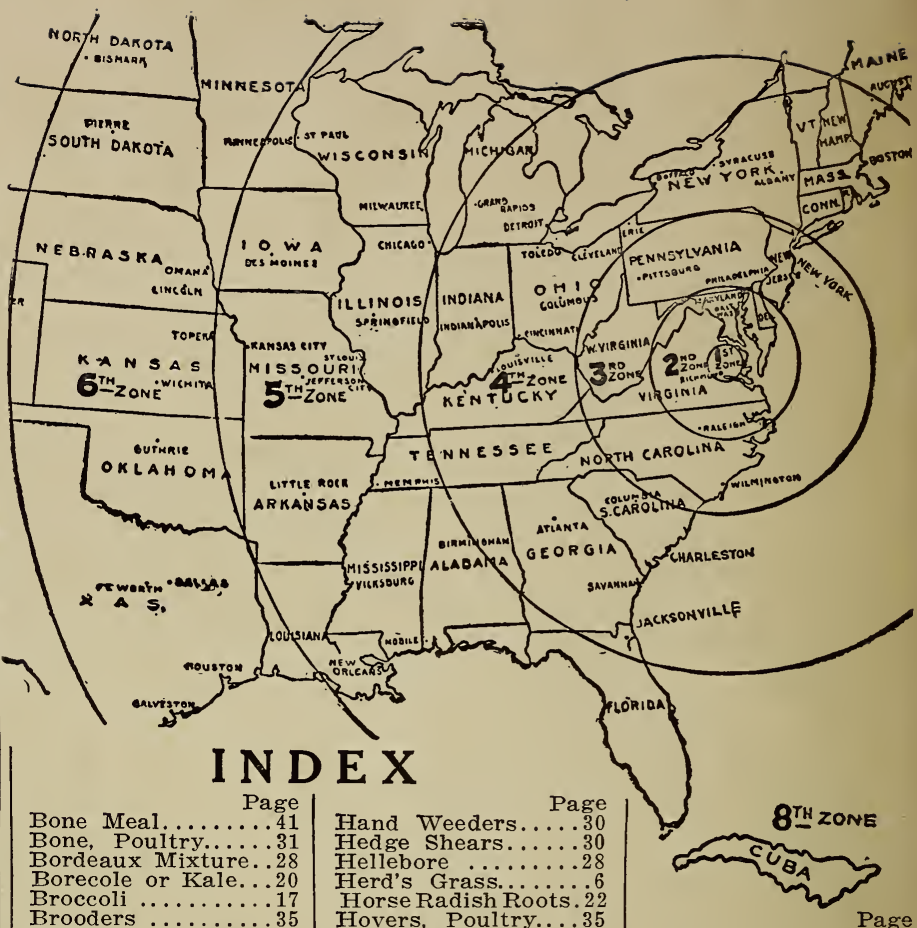

Hovers, Poultry....35 Hygrometer ........35 Incubators Cuitures Insecticides 16 Italian Rye Grass...7 Kerosene Emulsion.28 Ky. Blue Grass.....6 Rabi.

Land Plaster.......41 Lawn Enricher.......10 Lawn Grasses......10 Leg Bands.........35 Leek $\ldots \ldots \ldots \ldots 22$ Iice Killers......32, 33 McNair's Chicken$$
\text { Powder }
$$
Meadow Mixture..... Meat Scraps.........31 Mills, Grist and

Grinting $\ldots \ldots \ldots 35$ Mole Trap..........30 Trilford's Cultures.16 Mustard ........22 Mustard. Pouitry...32 Test $\mathrm{Fogs}$ Nitrate of Soda....41 nats Mninn sionds ands.2 14 Orchard Grass......5 Ovster Shell,

Pansv $\ldots \ldots \ldots \ldots .27$

Parcel Post Egg

Boxes ...........3 Paris Green..........? Peas, Canada Fieid, Peas. Garden.......? Panner $0 \ldots \ldots \ldots 22$ Potani Chinose... 19 Pigenn Fnnak.......31 Planet Jr. Tools..25, 30 Plants ............ Plant Fibre............39 Plant Sprinklers....3n Plaster. Land......41 Pots and Saucers...16
Poultry Appliances, Poultry Supplies.

Powder , 32. 33, 34. 35 Dusters.....29 Rabbit Food..........

Randall Grass....... 7

Rape

Red Top or Herd's Rhodes Grass......... 7 Rhubarb Roots...?4 Roup Remedies

Rust's Poultry

Ruta edies

Rye .........

Rye Grasses .......7

Scaly Leg Remedy. 23 Seed Sowers...8, 9. 11 Shears Manure...10, 41 Shell Crushed Oyster

Shipping Coops.

Slug Shot.....

Spinach ........

Spravers

Sprinklers. Plant....?

String Jute.......29 Sulpho-Tobacco Soan

Sulphur........28 Sweet Peas..........

Thermometers ........35 Thy-Cresol .......28 Timothy .......... 6 Tires, Automobile. 24 Tools. Garden...25 20 Trowels, Garden....2n Turnip ............25 Vegetable Plants. 11 Vetch Gias.............

Whale Oil Soap...28

Wreders .........?

Wheat ............... 13
Poultry Foods 34,35 Poultry Remedies, 33 Trop or Herd's 


\section{T.W.WOOD\&SONS SEEDSMEN}

Main Offices \& Stores:

11 South Fourteenth St. RICHMOND, VA.
Branch Stores:

Cor. Sixth \& Marshall Sts. 1707 East Franktin St.
Please forward the following as per terms of your Descriptive Catalog to

Name

$$
\text { (Ladies please use prefix Miss or Mrs.) }
$$

Post Office

R. F. D. No.

Box No.

State

Express Office

Freignt Depot

County

State

State whether to forward by EXPRESS, MAIL or FREIGHT

If to be sent by Mail be sure to include postage on goods not quoted postpat
AMOUNT ENCLOSED

Date .

P. O. Order

Express Order

Check or Draft

Cash

Stamps

Total.
Do not write in this space

TM PORTANT PLEASE WRITE YOUR ADDRESS PLA TLY and in full in the blanks above; also keep your order separate From other 1MP I matters you wish to write about. This enables is to fill orders more rapidly and correctly and your Inquiries will receive more prompt attention. Duplicate Order Sheets sent on request. 


\section{WOOD'S HIGH-GRADE CLOVER SEEDS Sow Wood's TRADE-MARK BRAND - There Is No Better}

The Red, Mammoth and Alsike Clovers, sown during August or September, will yield full cuttings next year, and a first-class soil-improving crop for turning under afterwards, to be followed by grain and other crops in the fall, giving considerable improvement to the soil and increased yield of crops to follow.

\section{Why Sow Clover}

It does not exhaust the soil, but improves it. To make two cuttings of fine hay a year.

To make an excellent pasture.

To put humus in your land.

To make your land friable and easily worked.

To increase the yield of the crop that follows it.

To save in your fertilizer bill by storing nitrogen in your soil.

Because it belongs in every crop rotation.

Because it is the corner-stone of good farming.

The sowing of Clover seed is absolutely essential to proper rotation of crops and to keep up the fertility of the land. Farmers should sow Clover seed liberally in order to keep up productiveness of the land for other crops.

The high price of cattle is an additional incentive to sow plenty of grasses and clovers in order to supply necessary feed and pasturage for all kinds of live-stock.

Clovers are the basis of successful farming, and are more generally used for hay, pasturage and soil-improving crops than set in clover not only makes a good forage or hay crop, but improves the condition and productiveness of the land at tice same time. In the rotation of crops, clovers are most valuable, and in nearly all sections of this country, excepting possibly the extreme South, are considered almost indispensable, and if our treme South, are considered almost indispensable, and if our proper rotation, they would spend far less for commercial fertilizers. A good crop of clover will restore fertility to land,
put more humus into the land than almost any other crop.

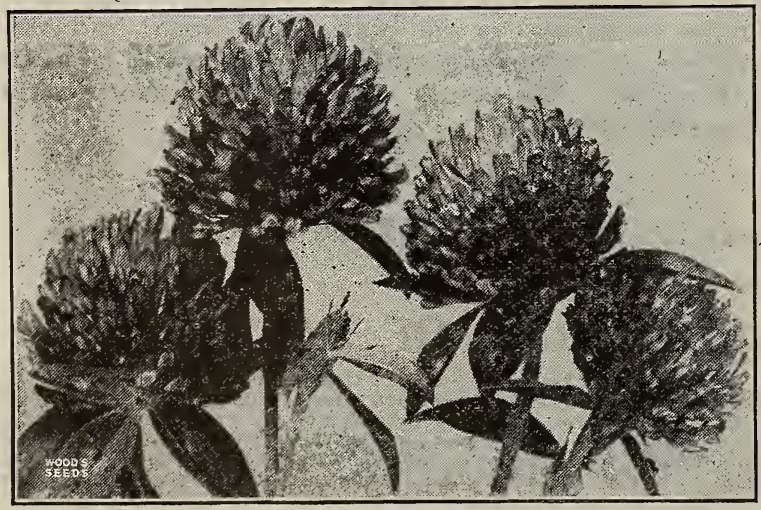

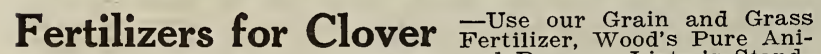
ard Bone Superphosphate-all are good. See back cover page for analysis and description.

\section{WHAT IS "TRADE MARK BRAND"?}

When we quote "Trade Mark Brand" it means the highest quality that money can buy, no weeds, no chaff, just pure seeds that have been thoroughly cleaned and carefully tested for germiration and purity.

\section{WHITE CLOVER}

\section{FOR IAWNS AND PASTURES}

This is very largely used in lawn and pasturage mixtures. It makes a small, close, compact growth, covering the ground like a carpet. Does well all through the South. Sow either in the
spring or fall. When sown by itself, sow 5 to 6 pounds per acre; it is better, however, sown in mixture with other grasses: By mail postpaid, $1 \mathrm{~b}$. 70 cts.
5 1bs. $\$ 3.15$; 10 1bs. $\$ 6.00$.
Sowing Grasses and Clovers in the Fall

When clovers and grasses are sown alone early in the fall, they will give good crops of hay or good pasturage the following year, and it is really preferable to sow them alone rather than with a grain crop, although they can also be sown very satisfactorily with fall-seeded oats, wheat or other grain crops, provided the grain crops are put in early.

The best method of seeding is to use the regular grain drills with grass and clover-seeding attachment; or, if this is not available, they can be sown either by hand or with a Cahoon Broadcast Seed Sower or a Cyclone Seed Sower-both are very satisfactory implements for seeding grasses and clovers.

When Grass and Clover seeds are sown with grain crops where the grain drills are not used, the grain should be seeded first and covered with a harrow, and then the grass and clover seed sown and covered with a light harrow or brush.

\section{Preparation for Clovers and Grasses}

A firm seed bed is of first importance, and the land should be well and deeply plowed, and then harrowed and reharrowed, so as to have the surface as fine as possible. It is always better to prepare the land for clovers and grasses, if possible, some time previous to seeding, and then wait for a good rain before seeding. As soon as the land is dry enough run the harrow over the soil to break the surface crust, then sow your grass and clover seeds, covering afterwards with a light or brush harrow, or a roller can e used if the ground is not wet.

Grass and Clover seeds should not be covered more than an average of about half an inch deep, but if sown on land that is not well prepared, it is almost impossible to prevent deeper covering. Our experience is so strongly in favor of a firm, wellprepared seed bed, that we feel we cannot urge it too strongly as of first importance if you desire good stands and good crops of grasses and clovers.

\section{RED CLOVER}

Red Clover not only furnishes most excellent pasturage and fine hay crops, but its growth improves the land and adds humus to soil wherever it is grown. The standard hay, pasturage and soil-improving crop wherever general farming is practiced.

Red Clover on good land will yield two cuttings per year. The first crop makes rich feed, and is the most valuable for hay. Red Clover should be cut for hay when in full bloom. For hay it is particularly well adapted for sowing with Orchard and Tall it is particularly well ad it ripens sowing with Orchard and sowing Meadow Oat Grass, as it ripens at the same time, and sowing
these three grasses together will give larger yield of better quality hay than sowing either alone.

A Good Mixture.-One bushel of Orchard Grass, one bushel Tall Meadow Oat Grass and eight pounds of Clover will give excellent results and if it is desired to use the land for pasturage also, the addition of six pounds of Herds Grass or Red Top will increase the pasturage and the second cutting of hay considerably. When sown by itself, sow 10 to $12 \mathrm{lbs}$. per acre, either in the fall or spring, or at the last working of corn.

Present price, TRADE-MMAR BRAND, by mail postpaid, lb. 58 cts.; 5 lbs. $\$ 2.75$; 10 lbs. $\$ 5.25$; bushel (60 lbs.) $\$ 30.00$.

\section{MAMMOTH, or SAPLING CLOVER}

Similar to Red Clover, both in the appearance of the seed and habit of growth; the difference being that it usually grows larger and is later in maturing. It is considered superior as an improver on account of the extra growth. It is a good variety for thin soils, or to seed with Timothy, Meadow Fescue or Herds Grass or Red Top, as it matures about the same time as these grasses. The appearance of the seed is identical with the Red Clover, and on this account it is impossible to distinguish any difference between them. We always obtain our supplies from reliable sources, but in this, as in all other seeds, we give no warranty but use every reasonable care to supply Mammoth or Sapling Clover as ordered. Sow 10 to 12 lbs. per acre by itself, or if sown with Timothy sow $6 \mathrm{lbs}$. of Clover and $8 \mathrm{lbs}$. of Timothy. Another mixture that we recommend is had by adding 6 lbs. of Herds Grass or Red Top to the Clover and Timothy. This has proved very satisfactory both for permanent pastures and for hay.

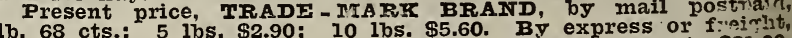

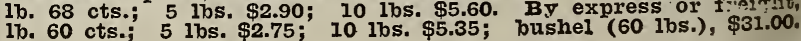


Makes an Excellent Winter and Spring Grazing Crop, the Best of Early Green Feed and a Good Hay Crop.

Sow in July, August or September, 15 lbs. to the Acre.

\begin{abstract}
CRIMSON CLOVER is considered one of the most valuable grazing and early forage and soilimproving crops for the Middle Atlantic and Southern States. A crop of Crimson Clover plowed under is considered worth 20 to 30 dollars per acre in increased productivity and improved mechanical condition of the soil. In addition, it is one of the best of winter and spring grazing crops, and also makes the best of early green food and a good hay crop.
\end{abstract}

Makes Excellent Fall, Winter and Spring Grazing

Crimson Clover is very desirable for dairymen, and makes excellent fall, winter and spring grazing. As a grazing crop, it is better to sow with rye. Also very valuable as cover crop for use in orchards. A great many farmers take advantage of every opportunity to sow Crimson Clover on all vacant lands to stand out through the winter, in this way furnishing a cover crop and a valuable soil-improving crop at the same time.

Crimson Clover can be very satisfactorily b-azed or cut for hay, and then the roots and stubble plowed under, with very considerable improvement to the land. It is siderable improvement to the land. It is crop, sowing it at the last working of corn each year, then plowing under the crop the following May and planting in corn, and growing increased crops of corn each successive year.

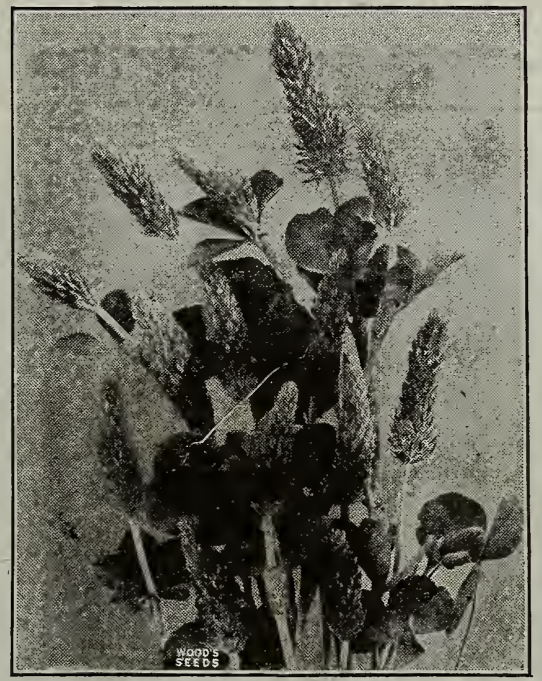

Crimson Clover.

Sow it in your Corn and Cotton at the last working, and next year you can plant Corn and Cotton on the same land and make bigger crops.

\section{WHEN TO SOW}

Crimson Clover can be sown to advantage any time from the end of July to early in October. It is best to prepare the land some time previous to sowing. and then wait for a rain to fall on the prepared soil before sowing the seed. As soon after a rain as the land is dry enough, a light harrow break the crust; then sow the clover seed. covering afterwards with a light or brush harrow. If this plan is followed out, it will almost invariably secure a good stand and good crop of Crimson Clover, no matter what the weather may be afterwards.

It is an excellent plan to sow rye or barfourths bushel per acre with Crimson Clover. This will increase the growth, insure a green cover crop, no matter what the weather conditions are after seeding, and will improve the quality and, if wanted for hay will make it easier to cure.

The sowing of Crimson Clover at the last working of corn and other cultivated crops gives an ideal preparation. In fact, it is surer to give a stand in this way than pared, as freshly plowed land is usually too porous, causing the seed to be covered too deeply, and not giving the little plant sufficient root-hold after it gets a stand.

\section{WHITE BLOOMING CRIMSON CLOVER}

We doubt if any will be available this year. We usually get our supply from Europe, and at the time this catalog goes to press it looks as though there will be none to be had. Europeans are having a hard time feeding themselves, and of course have given but little attention to seed grow. ing. Now that the war is over, no doubt it will be quite largely
grown, and we hope next season to be able to offer it as usual. If any can be had we will offer it in our CROP SPECrAL.

Present price, TRADE-MARK BRAND, by mail postpaid, lb. 30 cts.; 5 lbs. $\$ 1.15 ; 10$ lbs. $\$ 2.15$. By express or freight, lb. 25 cts.; 5 lbs. $\$ 1.00$; 10 lbs. $\$ 1.90$; bushel (60 lbs.) $\$ 10.50$.

\section{ALSIKE

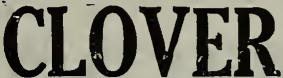

Sow 6 to 8 lbs. per Acre in August or September.

Alsike is the hardiest of the Clovers and does not winter kill. Lasts for several years.

Fine stemmed, leafy, and easily cured.

Particularly good for grazing.

Grows better on moist land than any other clover.

Should be in every sowing of mixed grasses.

Alsike Clover grows thicker, is finer stemmed than Red Clover. has plenty of leaf and makes better hay and more and better Erazing than Red Clover. It is hardier and will stand greater extremes of heat, drought and severely cold weather than any other clover. It is adapted to a variety of soils, succeeding on light upland and loamy as well as on bottom lands. Particularly valuable for grazing and in mixtures of grasses whether grown for hay or grazing. for it makes a thick undergrowth, greatly increases the yield as well as the feeding value of the hay.

If you have not succeeded in getting a stand of other clovers berause your land is acid or moist, sow Alsike.

Price, by mail postpaid, 1b. 55 cts.; 5 lbs. \$2.50; 10 lbs. \$4.75. 7 express or freight, lb. 50 cts.; 5 lbs. $\$ 2.35 ; 10$ lbs. $\$ 4.50$ wushel, \$25.00. Price fiuctuates.

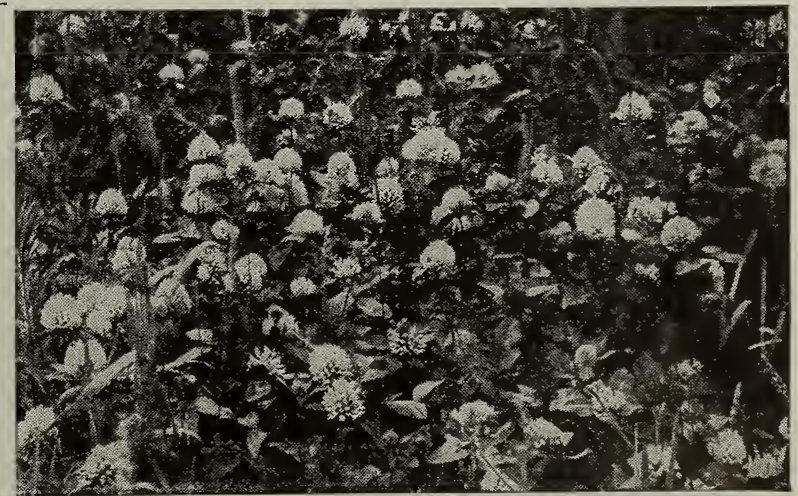

Alsike Clover. 


\section{WOOD'S HIGH-GRADE CLOVER SEEDS}

\section{Sow Wood's TRADE-MARK BRAND - There Is No Better}

The Red, Mammoth and Alsike Clovers, sown during August or September, will yield full cuttings next year, and a first-class soil-improving crop for turning under afterwards, to be followed by grain and other crops in the fall, giving considerable improvement to the soil and increased yield of crops to follow.

\section{Why Sow Clover}

It does not exhaust the soil, but improves it.

To make two cuttings of fine hay a year.

To make an excellent pasture.

To put humus in your land.

To make your land friable and easily worked.

To increase the yield of the crop that follows it.

To save in your fertilizer bill by storing nitrogen in your soil.

Because it belongs in every crop rotation.

Because it is the corner-stone of good farming.

The sowing of Clover seed is absolutely essential to proper rotation of crops and to keep up the fertility of the land. Farmers should sow Clover seed liberally in order to keep up produc-

The high price of cattle is an additional incentive to sow plenty of grasses and clovers in order to supply necessary feed and pasturage for all kinds of live-stock.

Clovers are the basis of successful farming, and are more generally used for hay, pasturage and soil-improving crops than set in clover not only makes a good forage or hay crop, but improves the condition and productiveness of the land at ti.e same time. In the rotation of crops, clovers are most valuable, and in treme South, are considered almost indispensable, and if our treme south, are considered almost indispensable, and if our proper rotation they would spend far less for commercial fertiproper rotation, they would spend far less for commercial fertiput more humus into the land than almost any other crop.

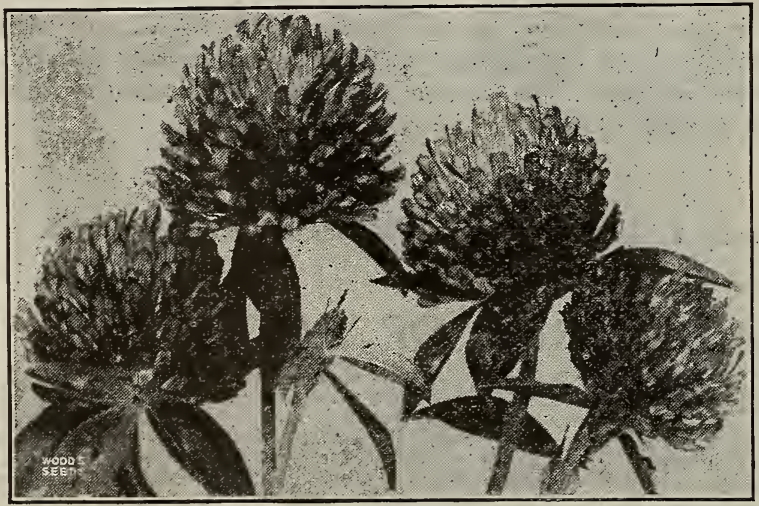

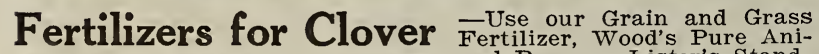
ard Bone Superphosphate-all are good. See back cover page for analysis and description.

\section{WHAT IS "TRADE MARK BRAND" ?}

When we quote "Trade Mark Brand" it means the highest quality that money can buy, no weeds, no chaff, just pure
seeds that have been thoroughly cleaned and carefully tested seeds that have been thorou
for germiration and purity.

\section{WHITE CLOVER}

\section{FOR IAWNS AND PASTURES}

This is very largely used in lawn and pasturage mixtures. It makes a small, close, compact growth, covering the ground like a carpet. Does well all through the South. Sow either in the spring or fall. When sown by itself, sow 5 to 6 pounds per acre; it is better, however, sown in mixture with other grasses. 5 1bs. $\$ 3.15$; 10 1bs. $\$ 6.00$.

\section{Sowing Grasses and Clovers in the Fall}

When clovers and grasses are sown alone early in the fall, they will give good crops of hay or good pasturage the following year, and it is really preferable to sow them alone rather than with a grain crop, although they can also be sown very satisfactorily with fall-seeded oats, wheat or other grain crops, provided the grain crops are put in early.

The best method of seeding is to use the regular grain drills with grass and clover-seeding attachment; or, if this is not available, they can be sown either by hand or with a Cahoon Broadcast Seed Sower or a Cyclone Seed Sower-both are very satisfactory implements for seeding grasses and clovers.

When Grass and Clover seeds are sown with grain crops where the grain drills are not used, the grain should be seeded first and covered with a harrow, and then the grass and clover seed sown and covered with a light harrow or brush.

\section{Preparation for Clovers and Grasses}

A firm seed bed is of first importance, and the land should be well and deeply plowed, and then harrowed and reharrowed, so as to have the surface as fine as possible. It is always better to prepare the land for clovers and grasses, if possible, some time previous to seeding, and then wait for a good rain before seeding. is soon as the land is dry enough run the harrow over the soil to break the surface crust, then sow your grass and clover seeds, covering afterwards with a light or brush harrow, or a roller can used if the ground is not wet.

Grass and Clover seeds should not be covered more than an average of about half an inch deep, but if sown on land that is not well prepared, it is almost impossible to prevent deeper covering. Our experience is so strongly in favor of a firm, wellprepared seed bed, that we feel we cannot urge it too strongly as of first importance if you desire good stands and good crops of grasses and clovers.

\section{RED CLOVER}

Red Clover not only furnishes most excellent pasturage and fine hay crops, but its growth improves the land and adds humus to soil wherever it is grown. The standard hay, pasturage and soil-improving crop wherever general farming is practiced.

Red Clover on good land will yield two cuttings per year. The first crop makes rich feed, and is the most valuable for hay. Red Clover should be cut for hay when in full bloom. For hay it is particularly well adapted for sowing with Orchard and Tall Teadow Oat Grass, as it ripens at the same time, and sowing these three grasses together will give larger yield of better quality hay than sowing either alone.

A Good Mixture.-One bushel of Orchard Grass, one bushel Tall Meadow Oat Grass and eight pounds of Clover will give excellent results and if it is desired to use the land for pasturage also, the addition of six pounds of Herds Grass or Red Top will increase the pasturage and the second cutting of hay considerably. When sown by itself, sow 10 to 12 lbs. per acre, either in the fall or spring, or at the last working of corn

Present price, TRADE-MARK BRAND, by mail postpaid, 1b. 65 cts.; 5 lbs. $\$ 2.90 ; 10$ lbs. $\$ 5.50$. By express or freight,

\section{MAMMOTH, or SAPLING CLOVER}

Similar to Red Clover, both in the appearance of the seed and habit of growth; the difference being that it usually grows larger and is later in maturing. It is considered superior as an improver on account of the extra growth. It is a good variety for thin soils, or to seed with Timothy, Meadow Fescue or Herds Grass or Red Top, as it matures about the same time as these crasses. The appearance of the seed is identical with the Red Clover, and on this account it is impossible to distinguish any difference between them. We always obtain our supplies from reliable sources, but in this, as in all other seeds, we give no warranty but us, but in this, as in all other seeds. Mammoth or Sapling Clover as ordered. Sow 10 to 12 lbs. per acre by itself, or if sown with Timothy sow $6 \mathrm{lbs}$. of Clover and $8 \mathrm{lbs}$. of Timothy. Another mixture that we recommend is had by adding $6 \mathrm{lbs}$. of Herds Grass or Red Top to the Clover and Timothy. This has proved very satisfactory both for permanent pastures and for hay.

Present price, TRADF-ITARK BRAND, by mail postriat,

lb. 68 cts. 5 lbs. $\$ 2.90$; 10 lbs. $\$ 5.60$. By express or f:oirlit 1b. 60 cts.; 5 1bs. $\$ 2.75$; 10 1bs. $\$ 5.35$; bushel (60 lbs.), $\$ 31.00$ 


\section{CRIMSON}

CLOVER

$\frac{\text { THE WONDERFUL }}{\text { SOIL IMPROVER }}$

\section{Makes an Excellent Winter and Spring Grazing Crop, the Best of Early Green Feed and a Good Hay Crop.}

Sow in July, August or September, 15 lbs. to the Acre.

\begin{abstract}
CRIMSON CLOVER is considered one of the most valuable grazing and early forage and soilimproving crops for the Middle Atlantic and Southern States. A crop of Crimson Clover plowed under is considered worth 20 to 30 dollars per acre in increased productivity and improved mechanical condition of the soil. In addition, it is one of the best of winter and spring grazing crops, and also makes the best of early green food and a good hay crop.
\end{abstract}

Makes Excellent Fall, Winter and Spring Grazing

Crimson Clover is very desirable for dairymen, and makes excellent fall, winter and spring grazing. As a grazing crop, it is spring grazing. As a grath rye. Also very valuable as cover crop for use in orchards. A great many farmers take advantage of every opportunity to sow Crimson Clover on all vacant lands to stand out through the winter, in this way furnishing a cover crop and a valuable soil-improving crop at the same time.

Crimson Clover can be very satisfactorily s.azed or cut for hay, and then the roots and stubble plowed under, with very con-
siderable improvement to the land. It is considered particularly valuable as a soil im crop, sowing it at the last working of corn each year then plowing under the crop the following May and planting in corn, and growing increased crops of corn each successive year.

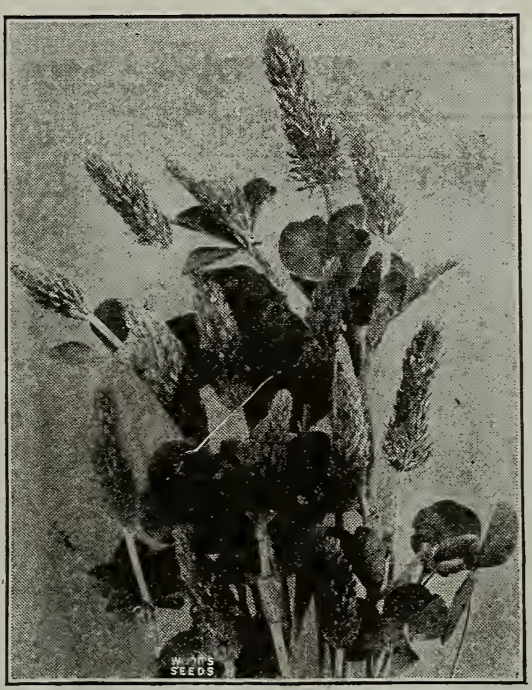

Crimson Clover.

Sow it in your Corn and Cotton at the last working, and next year you can plant Corn and Cotton on the same land and make bigger crops.

\section{WHEN TO SOW}

Crimson Clover can be sown to advantage any time from the end of July to early in October. It is best to prepare the land some time previous to sowing. and then wait for a rain to fall on the prepared soil before
sowing the seed. As soon after a rain as the land is dry enough, a light harrow should be run over the soil, in order to break the crust; then sow the clover seed, covering afterwards with a light or brush harrow. If this plan is followed out, it will good crop of Crimson Clover, no matter what the weather may be afterwards.

It is an excellent plan to sow rye or barley at the rate of about one-half to threefourths bushel per acre with Crimson sure a green cover crop, no matter what the weather conditions are after seeding, and will improve the quality and, if wanted for hay will make it easier to cure.

The sowing of Crimson Clover at the last working of corn and other cultivated crops gives an ideal preparation. In fact, it is surer to give a stand in this way than if the land is freshly plowed and freshly prepared, as freshly plowed land is usually too porous, causing the seed to be covered too cient root-hold after it gets a stand.

\section{WHITE BLOOMING CRIMSON CLOVER}

We doubt if any will be available this year. We usually get our supply from Europe, and at the time this catalog goes to press it looks as though there will be none to be had. Europeans are having a hord time feeding themselves, and of course have given but little attention to seed growing. Now that the war is over, no doubt it will be quite largely

grown, and we hope next season to be able to offer it as us
If any can be had we will offer it in our CROP SPECrAL.

Present price, TRADE-MARK BRAND, by mail postpaid, lb. 30 cts.; 5 lbs. $\$ 1.15 ; 10$ lbs. $\$ 2.15$. By express or freight, lb. 25 cts.; 5 lbs. $\$ 1.00 ; 10$ lbs. $\$ 1.90$; bushel (60 lbs.) $\$ 10.50$.

\section{ALSIKE CLOVER}

Sow 6 to 8 lbs. per Acre in August or September.

Alsike is the hardiest of the Clovers and does not winter kill. Iasts for several years.

Fine stemmed, leafy, and easily cured.

Particularly good for grazing.

Grows better on moist land than any other clover.

should be in every sowing of mixed grasses.

Alsike Clover grows thicker, is finer stemmed than Red Clover, has plenty of leaf and makes better hay and more and better rrazing than Red Clover. It is hardier and will stand greater crazing than fout an other clover. It is adapted to a variety of soils, succeeding on other clover. It is adapted to a variety of soils, succeeding on
light upland and loamy as well as on bottom lands. Particularly valuable for grazing and in mixtures of grasses whether grown for hay or grazing. for it makes a thick undergrowth, greatly increases the yield as well as the feeding value of the hay.

If you have not succeeded in getting a stand of other clovers

berause your land is acid or moist. sow Alsike.

Price, by mail postpaid, 1b. $55 \mathrm{cts} ; 5 \mathrm{lbs}, \$ 2.50 ; 101 \mathrm{bs} . \$ 4.75$.

$\overline{7}$ express or freight, 1b. 50 cts.; 5 lbs. \$2.35; 10 1bs. $\$ 4.50$; wushel, $\$ 25.00$. Price filuctuates.

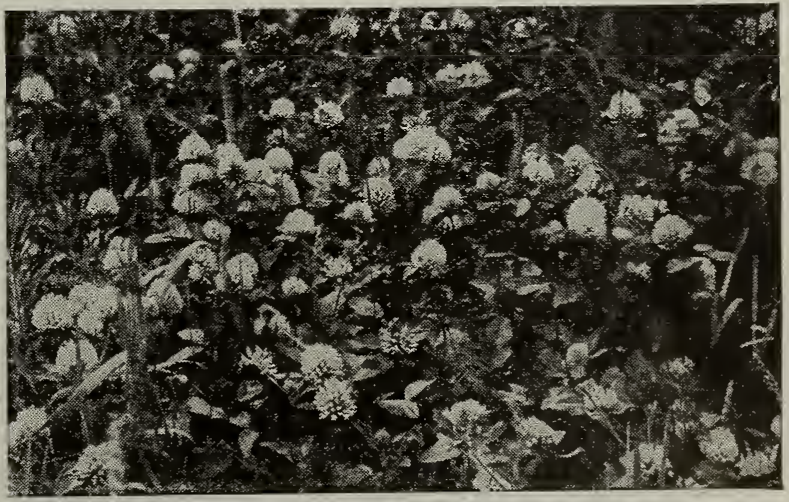

Alsike Clover. 


\section{ALFALFA}

\section{FACTS ABOUT ALFALFA}

Once established, it lasts for years.

Yields 3 to 5 cuttings nutritious and palatable hay each

season.
Feeding value high-contains as much protein as wheat bran.

Does not exhaust the soil; it enriches it.

Claimed to add twice as much nitrogen to the land as Red Clover.

Requires but little care and attention.

One of the farm's most profitable crops.

\section{RULES FOR SUCCESS WITH ALFALFA}

REMIFMBER YOU ARE MAKING AN INVESTMYNT on which you expect profits for a number of years, and that the size of your profits will be in proportion to the care exercised in preparing your land before you sow the seeds.

THE SOII. Sow only on deep, well drained, good loamy land that is not underlaid by a stiff hard pan that the roots cannot penetrate. When the roots reach this hard pan they either stop growing, or else grow horizontally along the top of the hard pan,
but the crop will not amount to much nor will it last very long. ITME ACID SOIrS. Alfalfa will not grow on acid soils. The bacteria that live on the roots of legume plants, like Alfalfa, drawing nitrogen from the air and making it available as plant ing a handful of soil from 2 or 3 ins. below the surface, wet it with rain water, if not already moist, insert a piece of blue litmus paper (get it at any drug store). If, 15 minutes later, the litmus p a p e r has changed to pink, your soil is 1 to $21 / 2$ tons of finely ground lime to the acre after plowing and a few weeks before sowing; in the meantime keep the harrows busy to kill out the weeds.

DRAINAGE. Alfalfa will not live with its feet in water, so
be sure the land is well drained. Good crops can be grown on lowlands if properly drained, either with tile or open ditches, to a depth of at least four feet.

INOCULATE YOU R SEFDS.

Do not attempt to grow Alfalfa without inoculating except on fields where it has previously been grown. Sow 300 to 500 on each acre: or send to us for on each acre; or send to us for one of the prepared and readyto-use 16

TK I I I THE WFEDS. Young Alfalfa plants are tender, and in the early stages of growth are likely to be killed by weeds. If you sow on land on which a cultivated or smothering crop has just been grown it will be reasonably free of weeds; but if you must sow on weedy land plow some time before sowing, frequent intervals, ten days or two weeks.

Four Cuttings of Alfalfa in One Season. two weeks.

Sow Wood's Trade Mark Brand Alfalfa. By express or freight, lb. 30 cts.; 5 lbs. $\$ 1.45 ; 10$ lbs. $\$ 2.80$; By express or freight, lb. 30 cts.; 5 lbs.
bushel (60 lbs.) $\$ 16.00$. Price fluctuates.

\section{SWEET CLOVER WHITE BOKHARA, or}

On lands too poor to grow a paying crop of corn, on worn out, galled, waste land, on land too sandy to grow any other crop, or too acid or too wet for other clovers, sow Sweet Clover, and after a few years the land can be brought into condition for general crops. It is adapted to a wider variety of soils than any other clover. It will be found useful for pasture, for forage, for bees for turning under to improve for it is a nitrogen gatherer, bees, for turning under to improve, for it is a nitrogen gatherer,
and for inoculating the land for Alfalfa. The deep roots break up, aerate and drain stiff subsoils and add humus. Its feeding value is high, containing 69 per cent protein, compared with 70 per cent in Alfalfa and 46 per cent in Red Clover. In spite of its bitter taste stock soon learn to like it. The first season it grows $1 \frac{1 / 2}{2}$ to $21 / 2$ feet high, but if cut when 6 inches high the plant stools out and makes a more tender growth for grazing. The second year it grows 5 to 10 feet high, and should be cut before the first blom buds before sowing; just stir the top soil, sow $20 \mathrm{lbs}$. to the acre, and harrow in.

HUIIED AND RECIFANTD SFEDS, by mail postpaid, lb. 45 cts.; 5 lbs. \$1.95; 10 lbs. \$3.75. By express, 1 b. 38 cts.; 5 lbs. $\$ 1.80$; 10 lbs. $\$ 3.50$.

SCARIFIED SEEDS, by mail postpaid, lb. 48 cts.; 5 lbs. $\$ 2.00$ $10 \mathrm{lbs}$. $\$ 3.85$. By express, $1 \mathrm{~b}$. $40 \mathrm{cts}$.; 5 lbs. $\$ 1.85$; $10 \mathrm{lbs}$. $\$ 3.60$. 


\section{WOOD'S HIGH-GRADE GRASS SEEDS}

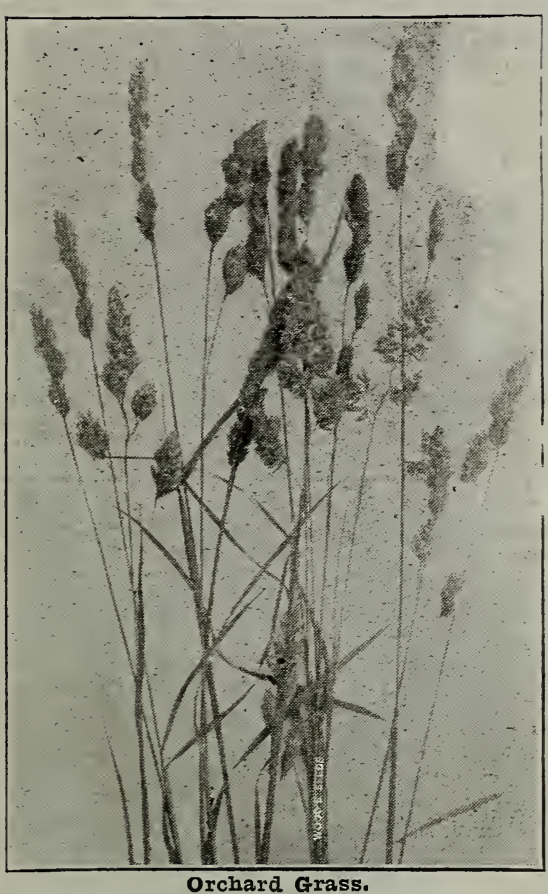

\section{Fall Seeding of Grass and Clover Seeds}

Fall seeding is to be specially recommended, for at that season the young plants do not have as hard a fight with weeds as in the spring. The end of August and during September is the best time for sowing in the fall, although they can be
safely put in up to the middle of October. If not sown by that time, defer sowing safely put in up to the middle of October. If not sown by that time, Re Top or Herd's Grass, Timothy and similar hardy grasses give quite satisfactory results if
sown before November 1st in the Eastern Carolinas and further South. Herd's Grass and Timothy are particularly hardy.

\section{Prepare Grass Lands Thoroughly}

Please read what we say on page 4 about "Preparation for Grass and Clover." When reading it bear in mind that when sowing grass and clover seeds you are making an investment; that you expect a profit from that investment for a number your land before the seeds are sown. The condition of the seed bed has much to do with the success of the crop, for to germinate freely the seeds must be in close Your profit also depends on the quality of the seeds you sow, so buy the bestWOOD'S TRADE-MARK BEAND.

The Descriptions of the various varieties of grasses in this catalogue we description of the varieties, the suggestive combinations with other kinds, the adaptability for various soils and conditions, with other information, will be found of especial use and value in arriving at correct cosired to be obtained.

PRICES IIUCTUATE.-The prices named in this catalogue are those ruling at we will quote you by mail or will fill all orders entrusted to us at the prices ruling at the time the order is received.

\section{ORCHARD GRASS}

A Valuable Grass for Both Pasture and Hay. Yields Two Hay Crops a Season. Drought-Resistant. Grows Well Under Trees. Sow Two Bushels per Acre.

Orchard Grass is a very vigorous grower and yields large crops of excellent and nutritious hay, as well as having special value as a pasture grass, furnishing good grazing from early spring till winter. It responds quickly of seasonable weather it is ready for grazing again. When cut for hay be sure to cut when in bloom, or as soon thereafter as possible, for if left too long after blooming the woody fibre forms in the plant and the hay becomes coarse. Orchard Grass is particularly well adapted for pastures, and has the further advantage of growing well in the shade, giving excellent results when sown in orchards and shaded parks. It adapts but succeeds best on loamy provided they are well sriff soils, although it does quite well on soils that are inclined to be of a sandy texture. It is a deep-rooted perennial grass, but does not form a true sod, as it grows in tufts, so it is recommended that other grasses be sown with it. For this purpose a mixture of one bushel Orchard Grass, one bushel Tall Meadow Oat Grass, and and is recommended for hay and pasture. If to be grown for pasture only, other grass $\mathrm{S}$, such as Red Top or Herd's Grass, Kentucky Blue, Meadow Fescue or Randal Grass, Perennial and Italian Rye Grasses and Alsike Clover may be added to make a permanent pasture.

To have Orchard Grass fields continue in a high state of productiveness a light seeding should be made each spring to fill in bare spots or where the stand has become thin. A top dressing of well rotted stable manure applied each winter will help materially in maintaining its productiveness. Fertilizers applied in March at the rate of 300 to 400 pounds to the acre give very satisfactory results. For this purpose wood's Grain and Grass results; for permanent improvement use Wood's Standard Bone Meal.

Present price, TRADE-MARK BRAND: By máil postpaid, 1b. 43 cts.; 5 lbs. \$1.65; bushel, \$4.35. By express or freight, 1b. 35 cts.; 5 1bs. \$1.50; bushel (14 1bs.), \$4.00.

\section{TALL MEADOW OAT GRASS \\ (FVRRGRFFN GRASS)}

One of the Most Valuable Hay and Pasturage Grasses for the South. Farly Maturing, Iarge Yielding; Especially Valuable in Combination with Orchard Grass, Both for Hay and Grazing

This grass is increasing in popularity wherever it is grown. It seems to make more leafage and grazing, a larger yield of hay, and to keep green longer, both during the winter and summer, than other grasses. It is especially desirable and adaptable to the South. It withstands the heat and drought of midsummer and cold of winter, starts very early in the spring, and continues to give good grazing until late in the fall. For hay it can be cut twice in a season, frequently producing nearly double as much hay as Timothy. Its nutritive qualities are first-class. It ripens at the same time as Orchard Grass, and gives the or as soon results sownile. Tall Meadow Oat Grass is best adapted for good while in bloom but gives excellent results on nearly all soils, and better results than any other grass on light, medium or sandy soils. Farmers who have been sowing this grass for years are especially well pleased with the returns from it, and are sowing constantly increasing acreage each year. When sown by itself, sow at the rate of two to three bushels per acre, either in the spring or fall. Sown with Orchard Grass and Red Clover, the quantities usually sown are one bushel (11 lbs.) Tall Meadow Oat Grass, one bushel (14 lbs.) Orchard Grass, and to the acre in this The addition of 6 or $7 \mathrm{lbs}$. Fancy Clean Red Top or Herd's Grass seed nation is excellent, and one that has given the most satisfactory results.

express, 1b. 35 cts.; 5 lbs. $\$ 1.60 ; 10$ lbs. $\$ 3.00 ; 1 b s . \$ 1.75 ; 10$ lbs. $\$ 3.25$. By freight or

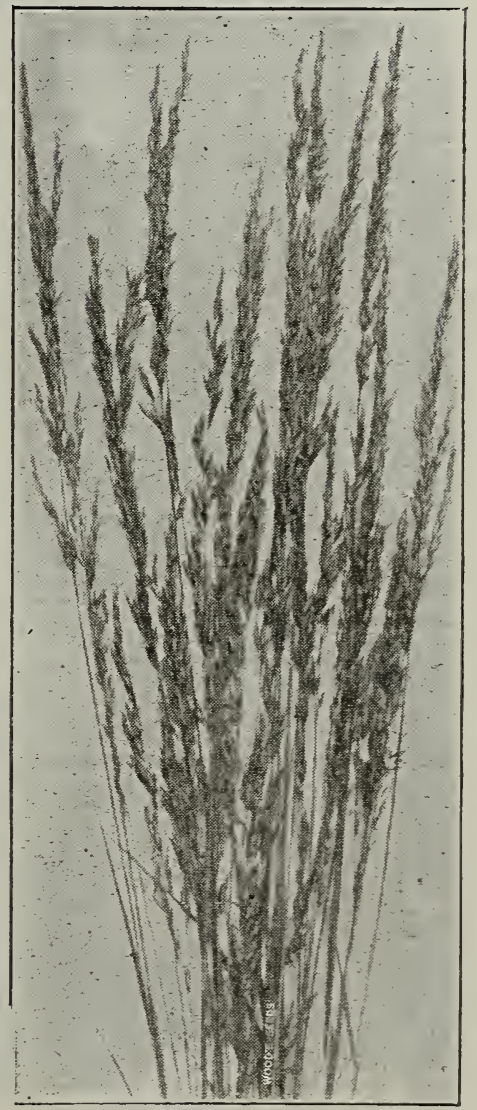

Tall Ireactow Oat Grass. 


\section{RED TOP, or HERD'S GRASS}

THE BIUT GRASS OF THE ATIANTIC COAST Sow 8 to 10 lbs. Iancy Cleaned Seeds to the Acre.

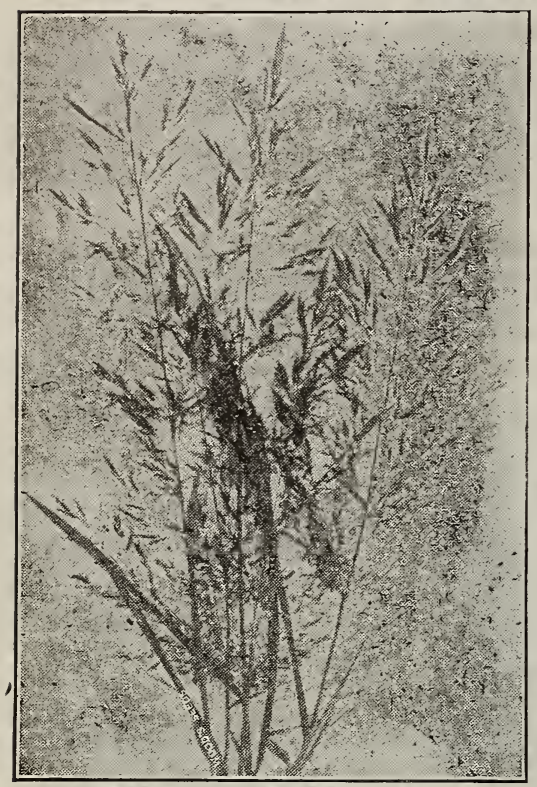

Red Top, or Herd's Grass.

is desired to put the land in cultivated crops. It makes excellent pasturage and good crops of fine quality hay. It is rather late in starting in the spring and matures its crops at the same time as timothy.

Red Top is excellently adapted for seeding with Timothy for hay, and furnishes excellent pasturage tablished it spreads and will gradtablished it spreads and will gradalso one of the best grasses for hillsides or lands likely to wash. When sowing with Timothy, sow 6 lbs. of Red Top or Herd's Grass and 8 lbs. of Timothy per acre. A or Herd's Grass, 8 lbs. Timothy 7 lbs. Meadow Fescue and 5 lbs give greater variety to the hay. and has proved very satisfactory. It can be sown either in the spring or fall.

Present price, TRADE - MARK BRAND, by mail postpaid; 1b. 25 cts.; 5 lbs. $\$ 1.10$; 10 lbs. $\$ 2.00$ 5 lbs. 95 cts.; 10 lbs. \$1.75; 100-1b. lots at $16 \frac{1}{2}$ cts. per $1 \mathrm{~b}$.

\section{KENTUCKY}

\section{BLUE GRASS}

The Grass That Made Kentucky Famous.

Sow 35 to $40 \mathrm{lbs}$. to the acre.

On lands that will grow Kentucky Blue Grass there is probably no other grass that equals it nor one that will yield a richer sweeter and more nutritious pas soils it should be included in all grass mixtures sown for grazing. It is one of the first to start up in the spring and gives the

finest grazing till snow flies. will withstand coldest weather,
and the trampling of hoofs does

Red Top or Herd's Grass is on ef the factory grasses for the South, and it is highly recommended that will not grow Kentucky Blue Grass. great variety of soils and situations, s u c ceeding well on light, stiff upland and low ground, and $\mathrm{g} \mathrm{r}$ ow $\mathrm{s}$ better in moist situaother grass. It is one of the easiest grasses to get a stand, a nd thickens and improves, taking possesincreasing in $y$ i e l d Red Top or Herd's Grass is really one of the most valuable of all $\mathrm{gras}$ es for the South, and it should be a large constituent intended for permanent pasture or hay. It seems indigenous to our Southern soils, and while it lasts a long time and spreads rapidly it is easily

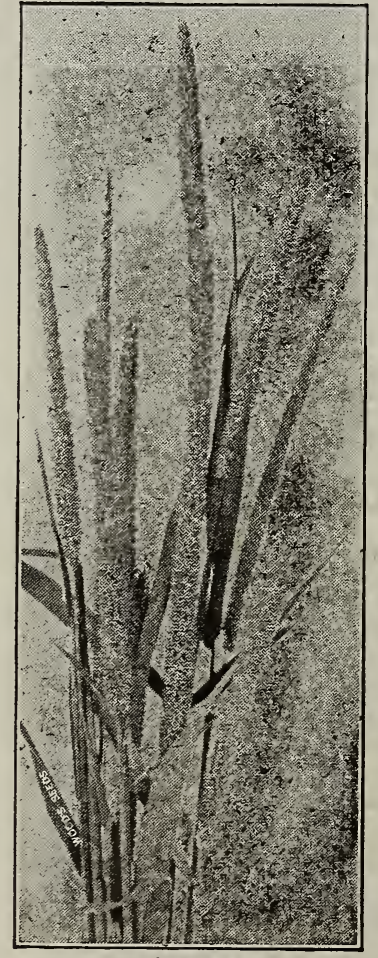

Timothy.

\section{KFNTUCKY BIUE GRASS-Continued}

not hurt it, as the roots are thick and stout, and form a tough sod, but do not turn stock on it till the grass is strong and well established. As it takes a year or more to become well established, we suggest that it be sown with at least one other grass. better mixture a single grass use Percky Blue, 6 lbs. Red Top or Herd's Grass, 5 lbs. Perennial Rye Grass, 5 lbs. Meadow Fescu or Herd's Grass, 5 lbs. Perennial Rye Gras,

Although slow to establish itself, Kentucky Blue Grass, once a stand is had on land to which it is adapted, lasts for many years, as the plants spread with their underground roots and will improve year to year, and rarely needs reseeding. A thick, well set sod of Kentucky Blue Grass makes an ideal pasture, and for all lands adapted to its growth should be one of the principal constituents of all pasture mixtures. Do not turn stock on Blu Grass pasture till the grass is strong and well established.

We recommend the sowing of Kentucky Blue Grass in the latter part of August till October 1st, but it can safely be sown up to November 1st if it becomes well rooted before freezing weather comes. Although we recommend fall sowing, it can be own either in the fall or spring.

Our Special Grass and Clover Pasture Mixtures described on page 8 all contain a liberal proportion of Kentucky Blue Grass.

Tresent price, TRADE-MART BRAND, by mail postpaid, 1b. 38 cts.; 5 lbs. \$1.60; 10 lbs. \$3.05. By freight or express, lb. 30 cts.; 5 lbs. $\$ 1.45$; 10 lbs. $\$ 2.80$; $100-1$ b. lots at $27 \mathrm{cts}$. per $1 \mathrm{~b}$.

\section{TIMOTHY}

\section{The Mrost Ixtensively} Grown Hay Grass.

A peck sows an acre.

For h a y, Timothy is the best known and most extensively grown of all grasses. A stand is easily established, it is inexpensive to sow, it starts best crop the year after it is sown, but the next year's crop may be equal$y$ as heavy if liberally top-dressed with stable manure. It $s$ tan $d s$ up well, is easily cured and is heavy for its bulk, for which reason it has ble hay crop when grown for market. The yield on good land frequently runs from $1 \frac{1 / 2}{\text { to }} 3$ tons to the acre.

Timothy requires good land to make good crops -this applies particularly to Timothy, for, unlike other grasses, it does not enrich the soil, but exhausts it, so that topdressing with stable manure or fertilizer is advised; the fertilizer amould contain a liberal amount of ammonia. If the clover will help to supply nitrogen.

The common practice in the West of sowing Timthy and Red Clover mixed is not recommended, as Red Cl o ver ripens

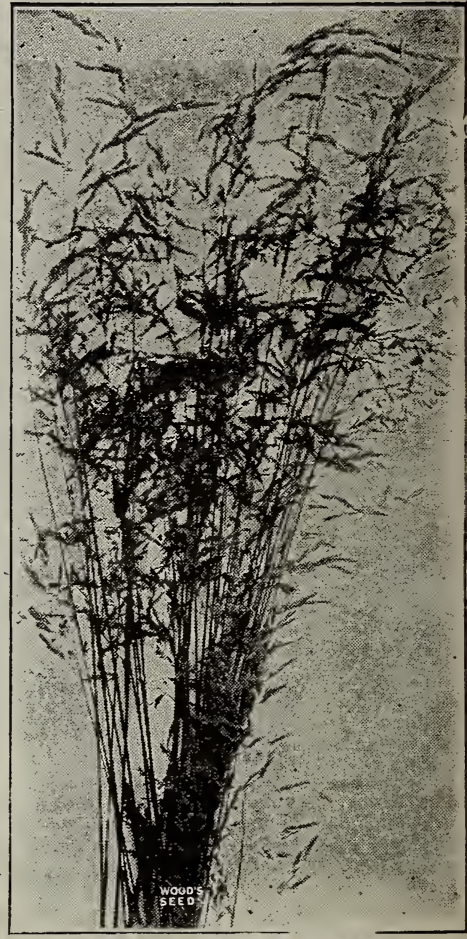

Kentucky Blue Grass. the latter is easily injured by early cutting and the hay shrinks in weight. The best time to cut is when it is in bloom; it is then Tim to cure and its feeding value is highest.

Timothy grows best on clay or heavy loam lowlands and in mountainous districts, but grows quite satisfactorily on any good my soil, provided there is abundant moisture.

Meadow Fescue or Randall Grass, Red Top or Herd's Grass and Sapling Clover all mature at the same season as Timothy, and are good grasses to sow with it for hay and grazing, increasing the yield of hay and the yield and value of the pasturage. A good mixture is 8 lbs. Timothy, 6 lbs. Red Top or Herd's Grass, $1 / 2$ bushel Meadow Fescue and 5 ibs. Sapling Clover: this mixture will furnish an excellent hay and fine pasturage on good loam toils or on low grounds. If Timothy and Sapling Clover

Present price, TRADI-MARK BRAND, by mail postpaid, 1b. 25 cts.; 5 lbs. 90 cts.; 10 lbs. $\$ 1.65$. B. freight or express, Ib. 18 cts.; 5 lbs. 75 cts.; 10 lbs. $\$ 1.40$; bushel (45 lbs.), $\$ 5.85$.

When we quote "postpaid" we pay the postage. Quotationg "by express" or "by freight or express" means you. pay the freight. 


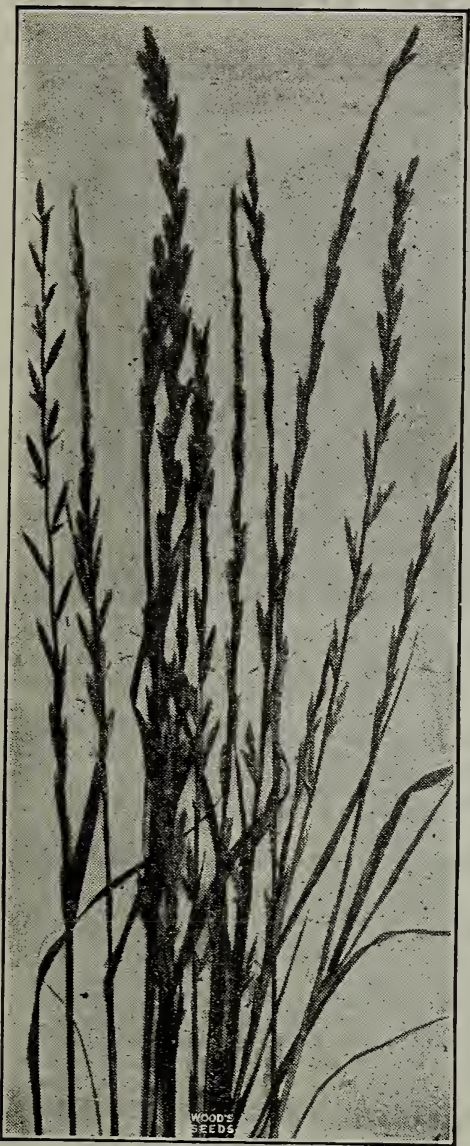

Italian Iye Grass.

\section{Meadow Fescue, or Randall Grass}

Meadow Fescue is particularly well adapted to our Piedmont and mountainous districts, and also gives excellent results on good loamy or heavy soils and on low grounds. It is a splendid spring and summer grass, stands close grazing, and makes more and thicker leafage than even Orchard and Tall Meadow Oat. Gra and making it quite drought resistant.

winter is esen throughout the makes a good hay, and cattle thrive on it whether green or dry. It succeeds well in nearly all sections of the South, and should be very. largely used in pasturage and hay mixtures, being especially suitable for sowing with Red Top and Timothy for hay, or with these and Orchard and Tall Meadow Oat for permanent pasturage. Sow either in the spring or fall at the rate of two bushels to the acre if sown by itself. A good mixture for hay, having Meadow Fescue for its basis, should contain $15 \mathrm{lbs}$. Meadow Fescue, 5 lbs. Red Top or Herds Grass, 5 lbs. Timothy, and 3 lbs. Sapling Clover. For grazing we recommend the addition of half a bushel each of Orchard Grass and Tall Meadow Oat Grass to this mixture.

Present price, by mail postpaid, 1b. $43 \mathrm{cts}$.; $5 \mathrm{lbs}$. $\$ 1.85$; $10 \mathrm{lbs}$. $\$ 3.55$. Iy express or freight, 1b. 35 cts.; 5 lbs. $\$ 1.70$; 10 lbs. $\$ 3.30$; $100-1 \mathrm{~b}$. lots at 32 cts. per $1 \mathrm{~b}$.

Crested Dogstail -Recommended only for pasturage or lawns in dry hard soils or hilllb. 43 cts.; 5 lbs. \$1.85; 10 lbs. \$3.55. By express or freight, $1 \mathrm{~b}$. 35 cts.; 5 Ibs. $\$ 1.70 ; 10$ lbs. $\$ 3.30$; 100-1b. lots at $32 \mathrm{cts}$. per $1 \mathrm{~b}$

Rhodes Crass in the late summer and fall, but further North spring sowing is recommended. Makes a rapid growth, 3 to 4 feet high, furnishing two or three cuttings of highly nutritive hay. By mail postpaid, lb. $68 \mathrm{cts}$; 5 lbs. $\$ 3.05$; 10 lbs. $\$ 5.90$. By freight or express, 1b. 60 cts.; 5 lbs. $\$ 2.90$; 10 lbs. $\$ 5.65 ; 100$-lb. lots at 55 cts. per $1 \mathrm{~b}$.

Bermuda Crass - This is recommended for spring seeding, although in the South it of the most valuable perennial pasture in the late spring and early fall to advantage. It is one hay in the far South. It also makes one of the best summer lawn grasses, to stand hot, dry weather, and is well adapted for this purpose for the lighter soils of the Southern States.

Bermuda Grass is a splendid grass for sowing on hillsides, railway embankments, millcams, etc., to bind the soil and prevent washing.

The ground should be well prepared, making a good, firm seed bed, as the seeds are small, gnd should be covered very lightly with a roller or bush harrow to a depth of not more than

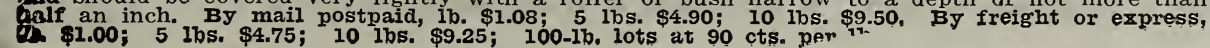
$\$ 1.00$; 5 lbs. $\$ 4.75$; 10 lbs. $\$ 9.25 ; 100-1 \mathrm{~b}$. lots at 90 cts. per 1

\section{Italian Rye Grass}

Sown in the fall, on good soil or on low ground, Italian Rye Grass furnishes full cutting of excellent and most nutritious hay the following May or early in June, and will growing of hay grasses, and will also furnish excellent pasturage during the fall, winter clovers, and some of our customers have had excellent results or with other grasses or

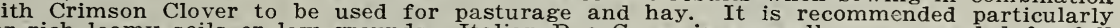
r, but it reseeds itself if allowed to stand. For hay it should be cut when heading out.

\section{Red or Chewing's Fescue}

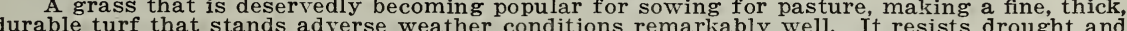
thrives on poor, dry soils, gravelly banks and exposed hillsides, making a close sod. Recom-

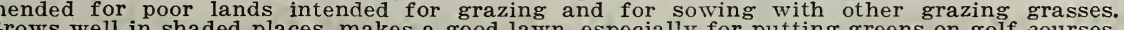
Grows well in shaded places, makes a good lawn, especially for putting greens on golf courses. 5 lbs. $\$ 1.70$; 10 lbs. $\$ 3.30$; $100-1 \mathrm{~b}$. lots at 32 cts. per ib.

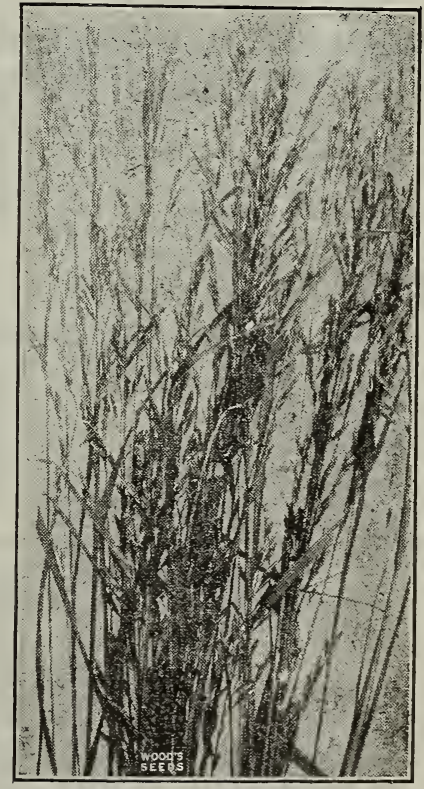

Mleadow Fescue or Randall Grass, 


\section{Wood's Special Grass and Clover Mixtures}

"Make Two Blades of Grass Grow Where Only One Grew Before"

Sown the Ind of August or During September, Will Field Full Crops of Fras or Grazing the Following Year.

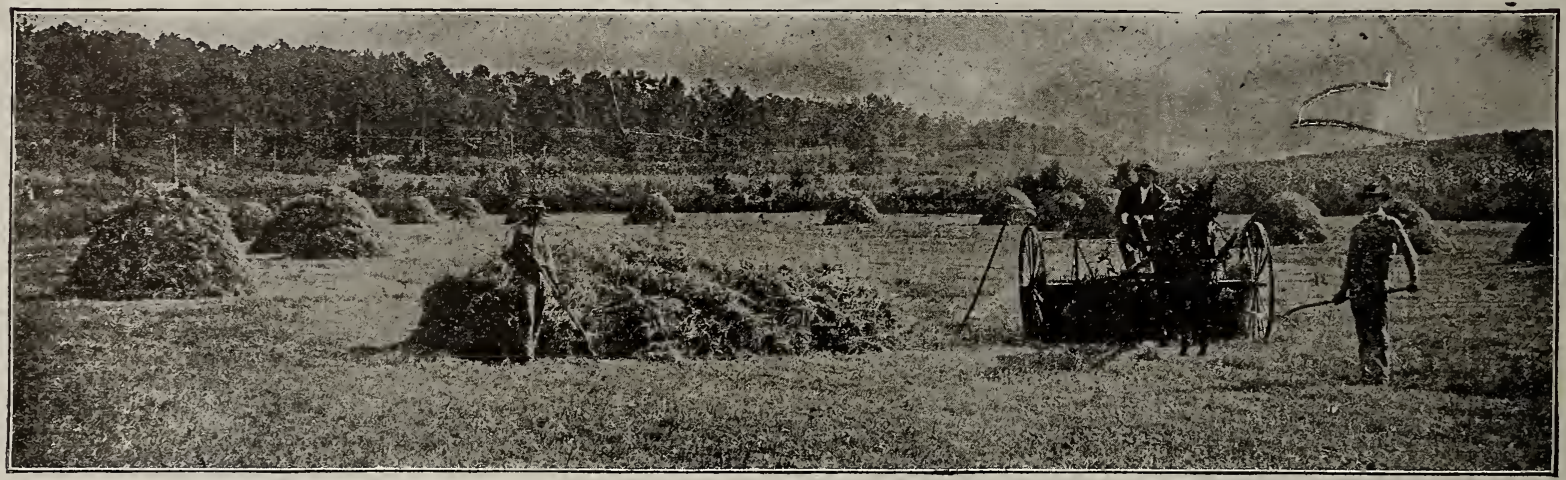

WHY SOW MMIXED GRASSES. - An eminent authority on grasses says: "I hold this proposition to be indisputable, that any soil will yield a larger and more nutritious crop if sown with several kinds of grasses than when sown with only one or two species. Indeed it is a well established fact that a mixture of only two or three grasses and clover will produce a less amount of hay than can be obtained by sowing a larger number of varieties together." Beal, in Grasses of North America, of several varieties will produce obtained when one variety is sown by itself yield than can be occupy the ground more completely than itself. Many sorts will out the weeds." Our own experience and observation fully confirm the statements of these authorities, and, judging by the increasing sales of our special Mixtures from year to year, our Southern farmers are recognizing more and more the advantage to be had from an intelligent and judicious mixture of grasses that have been combined to suit special soil conditions and for specific purposes. In this we have only copied nature, for in will find many different grasses, each supplyin food at its proper time during the eason. Every grass has its particular season when it reaches perfection, and by mixing in proper combinations and in correct proportions, each grass will do its part in supplying a

When a single grass is sown vacant spaces will occur throughout the field: these spaces in time will be occupied by weeds, whereas if a well balanced mixture of grasses is sown the entire surface is covered with good grasses that stock will delight to eat, your fields will give a better yield, an earlier yield, and for the entire season.

WOOD'S SPECIAI GRASS AND CTOVHR MIXTURES are made up from grasses in shown are best suited to the different soils and purposes for which they are recommended. Those for permanent pasture are composed of grasses which succeed each other in growth and give a succession from the first of spring till late in the winter in those for cutting for hay we have combined grasses which ripen together. The different mixtures are composed of grasses and clovers best adapted to the soils and situations for which they are recommended, and in such proportions as experience has proved will produce the best results.

\section{MIXTURES Nos. 1 to 5-For Permanent Pasture but will also make large yielding Crops of Hay}

MIXTURE NO. 1-For light, gravelly or sandy soils Composed of the following grasses and clovers:

Perennial Rye Grass

Red Clover

Alsike Clover

Tall ILeadow Oat Grass

Afalfa

Mreadow Fescue

Velvet Blue Grass

Sow 30 to $35 \mathrm{lbs}$. to the acre.

By mail postpaid, lb. 38 cts.; 5 lbs. \$1.60; 10 lbs. $\$ 3.05$. By express or freight, $1 \mathrm{~b} .30 \mathrm{cts}$; 5 lbs. $\$ 1.45 ; 10$ lbs. $\$ 2.80$; in 100-1b. lots, at $27 \mathrm{cts}$. per $1 \mathrm{~b}$.

\section{MIXTURE NO. 2-For good loam soil}

Composed of the following grasses and clovers: Tall MLeadow Oat Grass

MLeadiow Fescue

Orchard Grass

Perennial Rye Grass

Kentucky Blue Grass

Alfalfa

Crested Dogstal

White Clover

Red Top or Hexds Grass

Kentucky Blue Grass

Timothy

Red Fescue

By' mail to 35 libs. to the acre.

5 lbs. \$1.60; 10 lbs. \$3.05

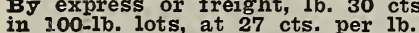

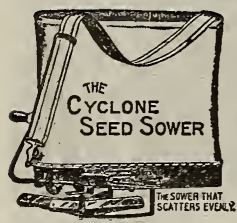

\section{A HANDY SEED SOWER}

The Cyclone is a splendid seed sower that will pay for itself in a few days in the time it will save, besides sowing grass and clover seeds and grain of all kinds faster and mor evenly and uniformly than is possible by hand. It will sow as fast as you can walk, and the quantity can be regulated to any By mail postpaid, $\$ 1.90$. By express, $\$ 1.75$

MIXTURE NO. 3-For heavy loam or clay soils Composed of the following grasses and clovers:

Alsike Clover

Orchard Grass

Red Top or Herds Grass

White Clover

Red Fescue

Meadow Fescue

Sow 30 to $35 \mathrm{lbs}$. to the acre.

By mail postpaid, 1b. 38 cts.; 5 lbs. \$1.60; 10 lbs. $\$ 3.05$ By express or freight, ib. 30 cts.; 5 lbs. $\$ 1.45 ; 10$ lbs. $\$ 2.80$ in 100-1b. lots, at 27 cts. per $1 \mathrm{~b}$.

MIXTURE NO. 4-For moist bottom land Composed of the following grasses and clovers: Kentucky Blue Grass

Timothy

Orchard Grass

Alsike Clover

ireadow rescue

Sow 25 to $30 \mathrm{lbs}$. to the acre.

By mail postpaid, 1b. 38 cts.; 5 lbs. \$1.60; 10 lbs. $\$ 3.05$ By express or freight, $1 \mathrm{~b} .30$ cts.; 5 lbs. $\$ 1.45 ; 10$ lbs. $\$ 2.80$; in 100-1b. lots, at 27 cts. per $1 \mathrm{~b}$.

MIXTURE NO. 5-For wet bottom land Composed of the following grasses and clovers: Red Top or Herds Grass Italian Rye Grass

Mieadow Fescue

Timothv Tall Mreadow Oat Grass Alsike Clover

Kentucky Blue Gras:

white clover

Mrammoth Clover

Sow 25 to $30 \mathrm{lbs}$. to the acre.

By mail postpaid, 1b. 38 cts.; By express or freight, $1 \mathrm{~b} .30 \mathrm{cts}$ in $100 \mathrm{lb}$. lots, at 27 cts. per $1 \mathrm{~b}$.
5 1bs. $\$ 1.60$; 10 lbs. $\$ 3.05$. 5 lbs. $\$ 1.45$; 10 lbs. $\$ 2.80$ 


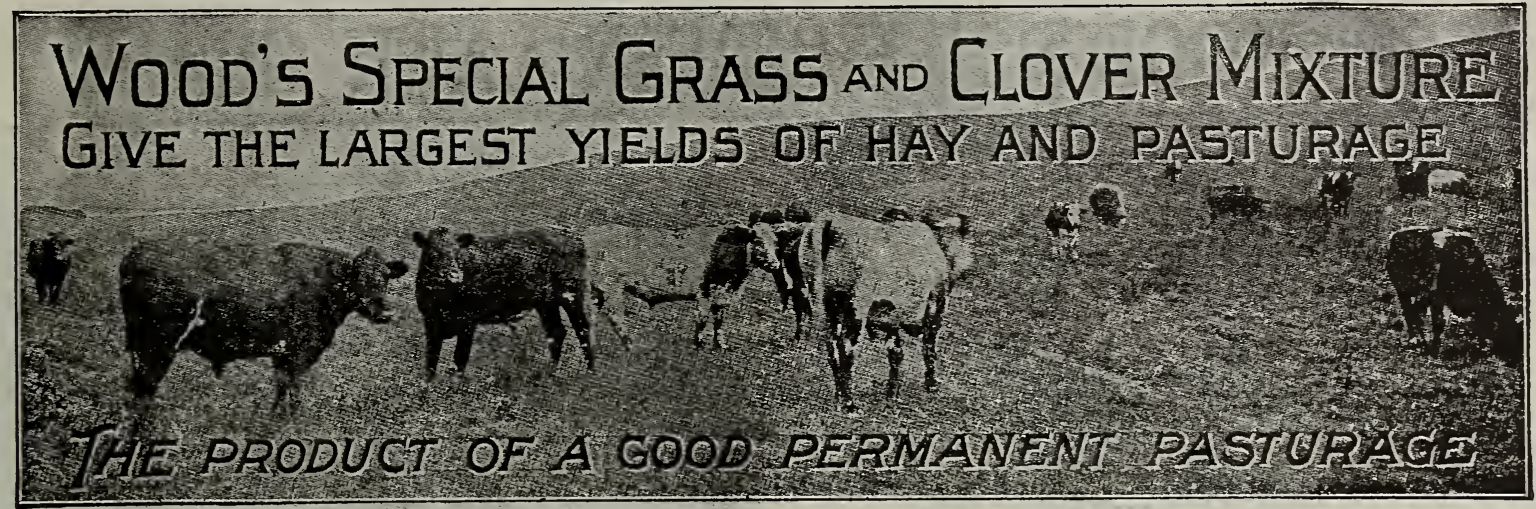

Mixtures Nos. 6 to 9-For Mowing for Hay; will also make splendid pasturage.

OUR SPECIAL MIXTURES for mowing for hay are composed principally of grasses which ripen together for the first cutting, but they also contain smaller proportions of other grasses which will increase considerably the second cuttings, and also add very much to the pasturage yield, in case it is desired to use the fields for pasturage afterwards.

MIXTURE NO. 6-For light gravelly or sandy soils Composed

Orchard Grass
Tall Mieadow Oat Gras:
Perennial Rye Grass

Red Fescue

Alsike Clover

Sow 30 to $35 \mathrm{lbs}$. to the acre

By mail postpaid, 1b. 38 cts; 5 lbs. \$1.60; 10 lbs. \$3.05. By express or freight, ib. $30 \mathrm{cts}$; 5 lbs. \$1.45; 10 lbs. \$2.80; in 100-1b. lots, at 27 cts. per $1 \mathrm{~b}$.

MIXTURE NO. 7-For good loam soil

Composed of the following grasses and clovers: Tall Mreadow Oat Grass

Mreadow Fescue

Orchard Grass

Red Top or Herds Grass

Timothy

Kentuck Blue Grass

Perennial Rye Grass

Red Clover

Alsike Clover

Alfalfa

Sow 30 to $35 \mathrm{lbs}$. to the acre. Italian Rye Grass

By mall postpaid, Ib. 38 cts.; 5 lbs. $\$ 1.60 ; 10$ lbs. $\$ 3.05$. By express or freight, lb. $30 \mathrm{cts}$; 5 lbs. \$1.45; $10 \mathrm{lbs}$. \$2.80; in 100-1b. lots, at 27 cts. per $1 \mathrm{~b}$.

\section{Wood's Fair Green Mixture}

Prepared Fspecially For the College Campus, Public Square, Baseball Parks, Etc.

Athletic grounds require grasses that will not only form a smooth, thick turf, but they must be grasses that will stand a great deal of rough usage; they must give a good playing surface throughout the year, especially during the summer. For this purpose repeated tests have proved that on public playgrounds, baseball parks, croquet lawns, public squares, the fair mixture which has Bermuda Grass for its base is best adapted.

In the South no grass stands more abuse, is more droughtresistant than Bermuda Grass, and none make a better summer lawn, but with it other grasses must be sown to have an allthe-year green growth. Our long experience enables us to offer mixture splendidly adapted to meet these requirements.

Although put up especially to meet the requirements of athletic grounds, this mixture is recommended for an all-the-year lawn in sections where Bermuda Grass is depended on for lawn making. By mail postpaid, 1b. 43 cts.; 5 lbs. \$1.80; $10 \mathrm{lbs} . \$ 3.25$. By ex-
press or freight, $1 \mathrm{~b}$. 35 cts.; 5 lbs. $\$ 1.65 ; 10$ lbs. $\$ 3.00 ; 100-1 b$. lots, 27 cts. per $1 \mathrm{~b}$.

\section{Putting Green Mixture}

Composed of the fine dwarf-growing grasses which produce the thick, velvety turf most desired by golfers.

There is probably no place where an absolutely smooth, perfect surface is more necessary than on putting greens. They require a strong, durable turf that will maintain a rich green the whole courts and for general lawn making.

By mail postpaid, $1 b .50$ cts.; 5 lbs, $\$ 2.00$; 10 lbs. \$3.75. By ezpress, 1b. 40 cts.; 5 lbs. \$1.85; 10 lbs. \$3.50; 100-1b. lots, at 32 cts, per $1 \mathrm{~h}$.

MIXTURE NO. 8-For heavy loam or clay soils Composed of the following grasses and clovers:

Meadow Fescue

Orchard Grass

Tall Mreadow Oat Grass

Kentucky Blue Grass

Sow su to 35 libs. to the acre.

By mail postpaid, 1b. 38 cts.; 5 lbs. \$1.60; 10 lbs. $\$ 3.05$ By express or freight, lb. 30 cts.; 5 lbs. $\$ 1.45 ; 10$ lbs. $\$ 2.80$; in $100-1 \mathrm{~b}$. lots, at 27 cts. per $1 \mathrm{~b}$.

MIXTURE NO. 9-For moist bottom land

$\begin{array}{ll}\text { Composed of the following grasses and clovers: } \\ \text { Red Top or Herds Grass } & \text { Italian Rye Grass } \\ \text { Timothy } & \text { Alsike Clover } \\ \text { IIeadow Fescue } & \text { Rentuck Blue Grass } \\ \text { Sapling Clover } & \text { Paspalum }\end{array}$

Sapling Clover

Sow 30 to $35 \mathrm{lbs}$. to the acre

By mail postpaid, 1b. 38 cts.; 5 lbs. \$1.60; 10 lbs. $\$ 3.05$ By express or freight, $1 \mathrm{~b}$. $30 \mathrm{cts}$; 5 lbs. \$1.45; 10 lbs. \$2.80; in 100-1b. lots, at 27 cts. per $1 \mathrm{~b}$.

\section{Meadow Mixture No. 10 \\ Sow 40 to $50 \mathrm{lbs}$. to the acre.}

In our Meadow Mixture No. 10 we have a mixture of grasses that has particular value and desirability for lands that are to be put down in permanent pasture. It is composed of an even greater variety of grasses than is contained in any of our other mixtures, is admirably adapted for both permanent pasture and for hay, makes a thick turf, and gives a splendid yield of grass greater number of grasses it contains it is adapted to a wider variety of soils than our other mixtures, each of which is prepared for lands of a certain character and for special purposes. except very light it for sowing on practically all kinds of solls

We have sold this mixture for a number of years, each year in increasing quantities and it is really gratifying to read the complimentary reports that come to us from all sections telling of the very satisfactory results had from our Meadow Mixture, both when grown for pasture and for hay.

By mail postpaia, 1b. $40 \mathrm{cts}$; 5 lbs. $\$ 1.70 ; 10 \mathrm{lbs}$. \$3.25. By express or freight, $1 \mathrm{~b}$. $32 \mathrm{cts}$; ; 5 lbs. $\$ 1.55$; $10 \mathrm{lbs}$. $\$ 3.00$; $100-1 \mathrm{~b}$. lots, $28 \mathrm{cts}$. per $1 \mathrm{~b}$.

\section{CAHOON BROADCAST SEED SOWER}

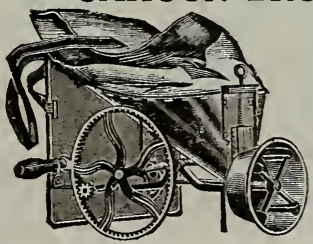

This seeder will sow any of the seeds that are usually sown broadcast, such as clovers, grasses, millet, buckwheat, vetch, turnips and all grains, and will do it more evenly and uniformly than you can possibly seed them by hand. It sows 4 to 6 acres an hour, or about as fast as you walk. The quantity per acre can be regulated for thick or thin seedice, by mail postpaid, $\$ 4.25$. By express, $\$ 4.00$. 


\section{IN AUGUST, SEPTEMBER AND OCTOBER SOW WOOD'S EVERGREEN LAWN GRASS}

From August 15th till October 15th-the earlier the better-is the best season to sow lawn grass. Sown at this time, the grass gets well established before freezing weather, makes a beautiful green lawn through the winter, and heat of summer and combat is strong enough sown lawn grass seeds have a hard fight with the weeds. so we strongly advise fall sowings.

\section{To Make a Lawn}

Remember when making a lawn that it is to last for years, and be and be preparation before the seeds are sown. Several weeks care to preparation lumps, apply Lawn Enricher or Sheep Manure, and rake the top soil; at intervals of ten days or two weeks rake the surface to destroy the weeds, and before sowing have the surface as fine as a rake will make it. Sow half the seeds, then sow the other half at right angles to the first sowing-this gives an even distribution. right angles to the first sowing-this gives an the seeds too deep After sowing, rake lightly so as not to cover the seeds too deep -covering with a roller is better-small seeds cannot germinate put stable manure on your lawn, as it adds to the many weeds already in the soil, and if not well broken up the lumps of manure will smother the young grass.

Weeds and Coarse Grass spring up naturally in all soils. After a soaking rain these can easily be pulled out and a few seeds scattered over the lawn to fill in the bare spots.

\section{Renewing Old Lawns}

A lawn can be kept thick and flourishing if at intervals the soil is stirred with a sharp rake and more seeds sown. This should be done just after the grass has been cut, or during a rainy spell. If rolled immediately after sowing the seed will be better covered. Every fall and spring fresh seeds should be

\section{WOOD'S EVERGREEN LAWN GRASS}

A quart sows 300 square feet; 1 1b. sows

400 square feet; 60 to $75 \mathrm{lbs}$. sow an acre.

Our Evergreen Lawn Grass is a mixture of grasses that are adapted to lawn making, and contains none of the coarse grasses nor those that grow in tufts or clumps. No one grass makes an ideal lawn grass, so we have put into our Evergreen a wellbalanced mixture of grasses that are at their best during different months of the year, will give a beautiful green growth at all. seasons, and will make a rich, deep green, velvety lawn in as short a time as possible. For years we have experimented with various grasses and combinations of grasses that are suited to lawn making and offer a lawn grass mixture that will give a thick and luxuriant turf, provided you follow the instructions given above and give your lawn the care and well established before the weeds start next spring. By mail postpaid, qt. 35 cts.; 1b. $50 \mathrm{cts}$; 5 lbs. \$1.60; 10 lbs. $\$ 3.00$; 25 lbs. $\$ 7.00$; 100-1b. lots, 26 cts. per $1 \mathrm{~b}$.

\section{WOOD'S LAWN ENRICHER}

One of the drawbacks in maintaining a lawn and keeping it green and flourishing is the fact that the grass uses up the supply of plant food in the surface soil, and unless this is replaced the grass weakens and dies. Wood's Lawn Enricher is specially made for lawns and contains all the plant food necessary to sustain a strong, healthy, luxuriant growth. Apply it generously when making the lawn, and every fall and spring give the lawn a top dressing so that the summer and freezes of winter.

Do not use stable manure on your lawn-it is disagreeable to handle is unsightly on the lawn, but worse still, it fills the ground with weeds that will be hard to get rid of. that are naturally of stronger growth than grasses, and will choke out the grass if allowed to remain and spread, besides making the lawn unsightly. When making and spread, besides making the laware feet, 800 lbs. to the acre, and work it into the soil a few days before sowing the seens. As a top dressing for old lawns, apply half the By mail postnaid. 5 lbs. 65 cts.: 10 lbs. $\$ 1.00$. B. express or freight, 5 lbs. 50 cts.; 10 lbs. 75 cts.: 25 lbs. $\$ 1.00 ; 100$ lbs. $\$ 3.50 ; 500$ 1bs. $\$ 17.00$; ton, $\$ 65.00$. Half ton at ton rate.

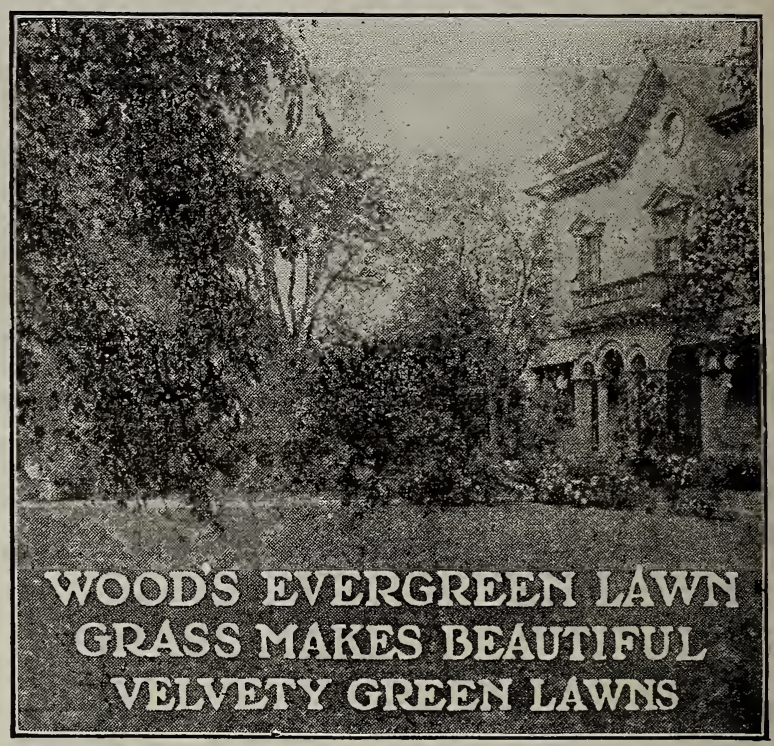

\section{WINTER LAWN GRASS}

1 1b. sows 300 square feet; 40 to 50 lbs. sow an acre. In parts of the South, Bermuda Grass is depended on for lawns, but it does not remain green throughout the winter. On such lawns a sowing of our Winter Lawn Grass will give a constant green, luxuriant growth all the year round. When sowing on Bermuda sod, scarify the sod with a sharp rake or harrow, sow the seeds at the rate of $1 \mathrm{lb}$. to 300 square feet, or 40 to $50 \mathrm{lbs}$ to the acre, and cover with a rake or harrow-a roller is even better. Winter Lawn Grass can also be sown alone on a lawn prepared as described above under "To Make a Lawn." On the grounds of Southern hotels and cottages that are used as winter resorts, it will give a most satisfactory green lawn throughout

By mail postpaid, Ib. 35 cts.; 5 Ibs. \$1.50; 10 Ibs. \$2.75. By ex press, 1b. 30 cts.; 5 lbs. \$1.35; 10 lbs. $\$ 2.50 ; 25$ Ibs. $\$ 5.85$ 100-1b. lots, 22 cts. per 1b.

\section{WOOD'S PERMANENT LAWN GRASS}

1 lb. sows 300 square feet; 40 to 50 lbs. sow an acre.

This mixture is composed of robust-growing grasses, and is designed to supply a satisfactory mixture for parks or larg places where lawn and grazing are to be combined, or wher special care and attention cannot be given to the lawn. Thi mixture will stand dry, hot weather better than the finer lawn

Brasses. $3 \nabla$ express, Ib. 35 cts.; 5 Ibs. $\$ 1.60$; 10 Ibs. $\$ 3.00 ; 25$ Ibs. $\$ 6.85$ 100-1b. lots, 25 cts. per $1 \mathrm{~b}$.

\section{SHADY PARK LAWN GRASS}

A special mixture of grasses adapted to growing under trees and in shady places where it is difficult to get other grasses tn grow. By mail postpaid, Ib. 50 cts.; 5 lbs. $\$ 2.05 ; 10$ Ibs. $\$ 3.95$; 100-1b. lots, 35 cts. per $1 \mathrm{~b}$.

\section{SHEEP MANURE}

Dried and pulverized; no weeds, straw and refuse. On now lawns apply $10 \mathrm{lbs}$. to 100 square feet; as a top dressing. $10 \mathrm{lbs}$. to 200 square feet. By mail postpaid, 5 lbs. 45 cts.; 10 lbs. 75 cts. By express or freight, 5 lbs. 30 cts.; 10 lbs. 50 cts.; 25 Ibs. 90 cts.; 50 lbs. $\$ 1.50$; 100 lbs. $\$ 2.50$; 500 lbs. $\$ 11.75$; ton, $\$ 45.00$ Iralf-ton at ton rate. 


\section{DWARF ESSEX RAPE The Economical Pasture Crop Fattens Sheep Without Grain}

Sow It for Fall, Winter and Spring Pasturage for Sheep, Hogs, Cattle and Poultry.

Sow it curing August, September and October-
3 to 4 lbs. per acre in drills; 6 to 8 los. broadcast.

Formerly rape was grown especially for sheep and lambs, but in recent years it has been found equally good for providing pasture for
all kinds of stock. It has been estimated to yield more than 10 tons of green forage per acre that, for fattening is claimed to be worth, pound for pound, double the value of clover. One of the' State experiment stations reports that the lowest average gain on lambs fed on rape alone was 7 to $8 \mathrm{lbs}$. per month. Another experiment station recommends the sowing. of 3 to $4 \mathrm{lbs}$. rape to the acre in corn at the last working, and stating that this has proved a particularly profitable practice, as an enormous crop can be grown at a cost of about 50 cts. per acre. According to a recent Government bulletin, an acre f rape with grain will fatten twenty wethers in two months.

Do not turn stock into a rape pasture when they are hungry, nor when the rape is wet, as it may induce bloating; allow them to
remain a short while the first day, and increase the time each succeeding day. Give stock access to salt while feeding on rape. and cultivated occasionally the leaves will cover the intervening space: this method is a fine weed killer. 3 to 4 lbs. plants an acre in drills 6 to 8 lbs. broadcast. Allow 8 to 10 weeks for it to attain its maximum growth.

Iy mail postpaid, 17). 23 cts.; 5 lbs. 90 cts.; 10 lbs. \$1.E5. Ey express or freiglht, $1 \mathrm{~b}$. $15 \mathrm{cts}$; $10 \mathrm{lbs}$. $\$ 1.40$; 100-1b. lots, $12 \mathrm{cts}$. per $1 \mathrm{~b}$.

\section{WINTER BARLEY}

Under Arlington Beardless Barley, described below, will be found the many uses to which fall sown barley is adapted, all of which, except reference to the beard, applies to Winter Barley. Care should be exercised to be sure that you plant only Southern grown seeds. We handle Bushel, \$2.35; 5-bushel lots, \$2.25 per bushel. Price fluctuates. No charge for bags.

\section{ARLINGTON BEARDLESS BARLEY}

\section{In the South barley has a particular value, as it furnishes not} only fine grazing during the fall, winter and spring, but also makes a hay that in feeding value is equal to timothy. There

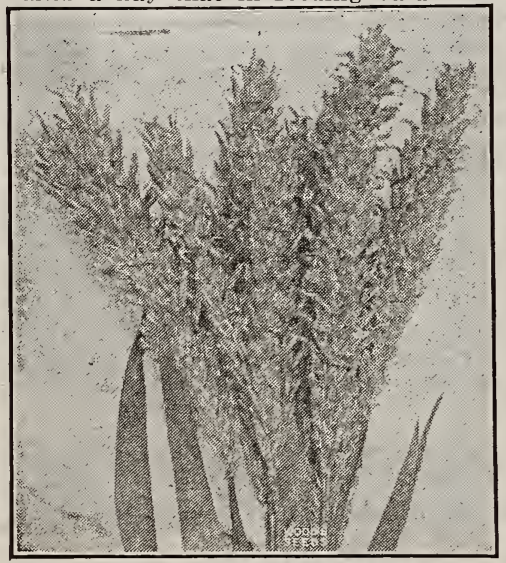

Arlington Beardless Barley. grass cannot be successfully grown, but where barley, oats, rye and wheat can be grown as a hay crop. All of hay if cut before it heads out, and are easy to cure. Of all the making, barley is most generally preferred, and A rlington, being a beardless variety, is particularly well adapted for this purpose; in some sections that do not grow grasses well pended on almost en tirely for hay.

A $n$ ot h e $r$ advantage that should not be overlooked is that after grazing it quite a fair harvested, provided it is not grazed too late.

It can be economically grown by sowing in corn and cotton at the last working, no other preparation being necessary; the entire cost would be only the cost of the seeds. Barley is so easily grown and does so well in the South that it should be very generally grown. If you have a piece of land that will be unoccupied next winter sow barley to prevent the winter rains from washing out the plant food from the soil. Sow it if there is a prospect that you will be short of grazing next winter and spring, or hay next summer. $11 / 2$ to 2 bushels broadcast sows an sow only Southern grown barley.

Bushel, \$3.00; 5-bus. lots and over, \$2.90 per bus.

The Barley I got from you has done very well and made very good pasture after January, although I sowed it too late, the last part of October.-J. H. CALAME, Pittsylvania Co., Va.

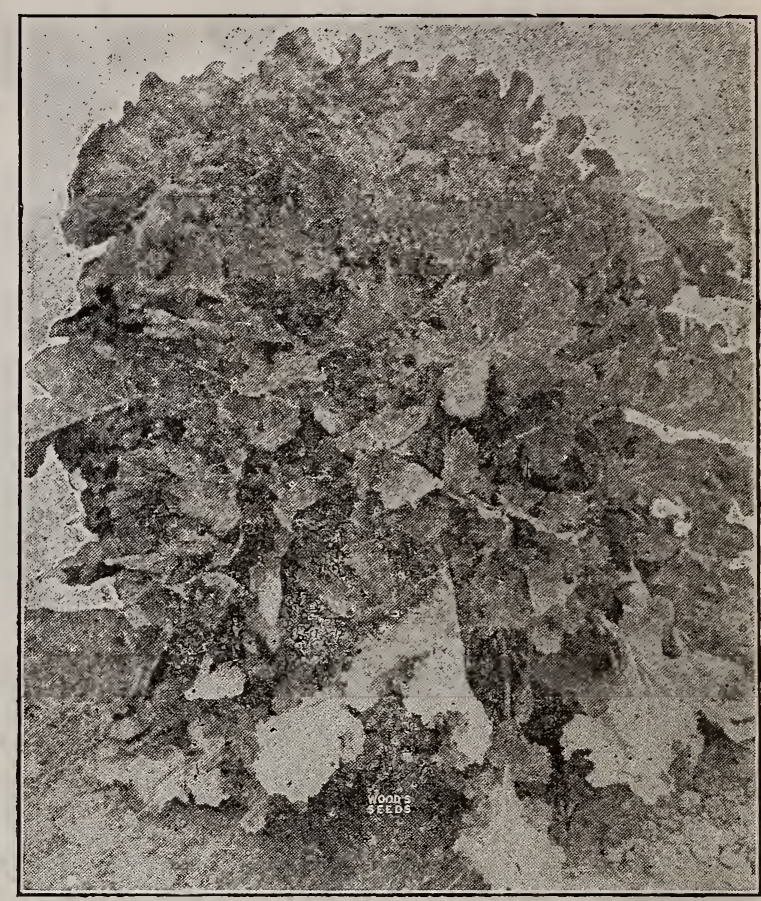

Dwarf Issex Rape.

\section{CANÁDA FIELD PEAS}

Canada Field Peas malie. a fattening and milk producing food that will grow on land that will not produce a grain crop, and at the same time improve the ing nitrogen - in this respect it is almost equal to heavy crops that may be either grazed or made into either grazed or made into hay that stock eat greedgrow 4 to 5 feet high, but can be grazed when 6 to 10 inches high. If not grazed t o o closely, a s e c ond growth may be had, and if conditions are favorable. Pasturing the peas makes them stool out better and results in a finer growth of vine and a better hay.

CUITURE.-Sow in October, November or December, one bushel to the acre and plow in 4 inches deep. after which drill in one bushel of Rust-Proof Oats to the acre to hold the vines off the ground; if sown alone sow $11 / 2$ bus. to
the acre. Fall sown peas the acre. Fall sown peas come up earfy is soon as the weather opens.

Price fluctuates. Present price, $\$ 3.50$ per bus.; 2 -bus. cotton bags, 60 cts. extra.

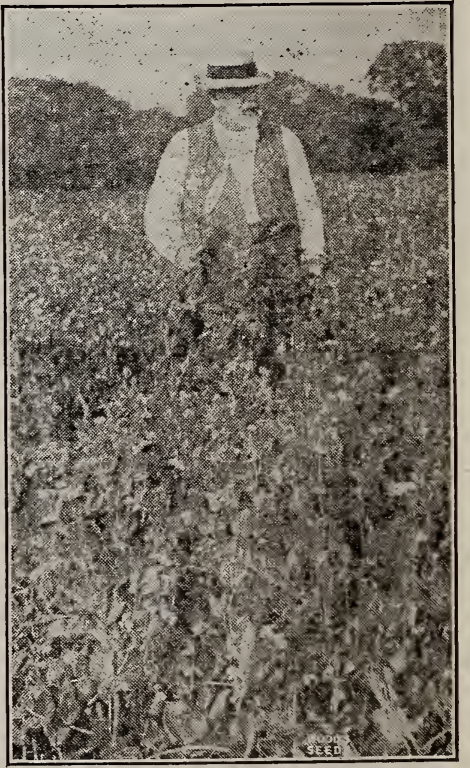

Canada Field Peas.
It gives me pleasure to say that the Canada Field Peas gave a grea amount of splendid hay, which was cut and cured the first week in June. All kinds of stock relish it, and it saves grain when feeding it to
horses. Shall sow more of it.-A. E. DILLEMATH, Nottoway Co.. Va. 


\section{SEED WHEAT}

\section{A Warning from Washington}

A disease known as nematode galls has appeared in wheat grown in certain sections, and to such an extent that the United States Department of Agriculture has sent out a warning to wheat growers to guard against sowing wheat grown in the infected districts. Nematode galls not only reduce the yield per acre but they seriously affect the quality of the crop and the market value. We know exactly where this clisease is prevalent, and none of our wheats are is prevalent, and none of our

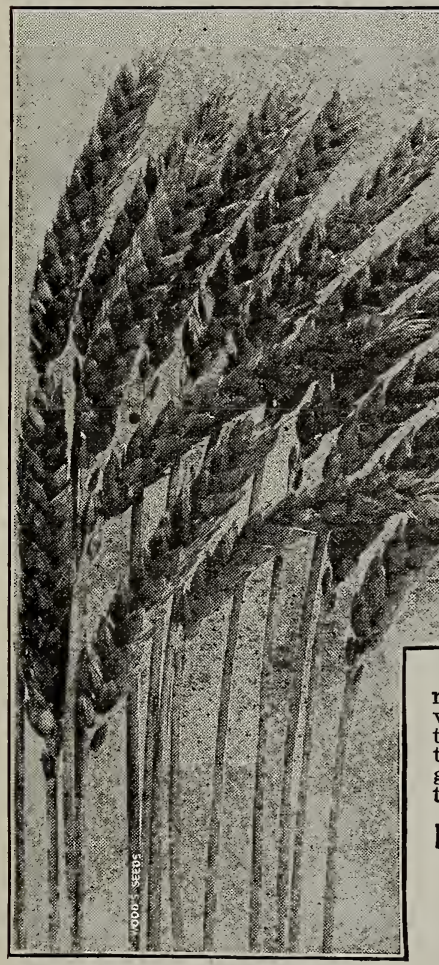

Ieap's Prolific wheat. that less seed will plant an bushel to the acre is claimed will give as good results as five pecks to the acre with other kinds; our experience, when testing various quantities sown per acre, is that a bushel to the acre is the proper quantity to plant. Miracle Wheat makes a fine heavy grain of excellent milling quality, and with favorable growing conditions you will not be disappointed with the yield. Bushel, \$3.10; 5-bus. lots, $\$ 3.00$ per bus.

Red Wonder - We have reports from wheat farmers in sections where wheat is grown as the money crop, that Red Wonder had run five bushels and more to the acre than other wheats grown in the same vicinity. This increased yield, considered in connection with the fine appearance of the grain, means more money for the wheat crop, for millers will pay a premium for large flinty wheats that will show a good handsomest wheats in our list, has a stiff straw and stands up well. Bushel, $\$ 3.10$; 5-bus. lots, $\$ 3.00$ per bus.

By the use of the most improved modern cleaning machinery, we supply Seed Wheats as clean as machinery can make them. All foreign matter and shrunken and undeveloped grains that would produce weak plants are taken out. We ship in new grain bags, for which no charge is made.
SEED WHEAT PRICES At the time this catalog is printed seed Wheat values are not fixed, and we can only print approxith each catalog we will send a copy of the latest issue of our quoting prices of seed wheats and other seasonable seeds on later issues of the CROP SPECIAL, or we will gladly quote prices

\section{Smooth or Beardless Wheats}

It may be that smooth or beardless wheats have a tendency to sport; or a cause all smooth wheats, even new varieties, like the crop. Whatever may be the always possible tooth kinds, but owing to the varying nature of wheat, it is not Leap's Prolific -Although a comparatively new variety, Leap's Prolific has fairly leaped into popularity. It originated in Virginia, and seems to be particularly well adapted to the Atlantic seaboard. From every sec-
tion, from Virginia to the Gulf, have come the most enthusiastic reports of large crops and the fine milling quality of the flinty grains. It stools to a greater degree than most varieties, is early to ripen, is a strong grower, stiff strawed mend it highly for its milling quality as well as for yield. Bushel, $\$ 3.10$.

filz the Fultz were not such a sterling wheat it would long since have been most popular and generally planted. It has a good berry, stiff straw, is

Fultz. Bushel, $\$ 3.10$; 5-bushel lots, $\$ 3.00$ per bushel makes of its good yields and reliability, but the millers like it because it as any wheat grown in the South Atlantic States. It is somewhat similar to Fultz, and whatever good qualities may be claimed for Fultz are equally true

\section{Bearded or Longberry Wheats} In a large measure this accounts for the disappearance of the old-time prejudice against the smooth kinds. Bearded wheats usually give better yields than smooth wheat on low

Miracle or Stoner $-\mathrm{Th}$ is was discovered in the upper they grow wheat crops such as are not equalled by any attracted attention by its attonderful stooling b 然-

D

-Mediterranean -A superior longberry wheat that has it has been grown. Its popularity has been built up largely on its good milling qualities for it makes the best of flour and the millers are partial to it. Its stiff straw enables, it to stand up well, and no wheat withstands adverse weather conditions better than Deitz. We regard it as a very satisfactory wheat, one that we can

\section{FORIMALIN PREVENTS SMUT}

Smut in wheat, oats, rye and barley reduces the yield and lowers the whart be prevented by treating your seed grain with FORINAIIN.

Spread the grain thinly on the barn floor and with a watering pot sprinkle it with FORMAIIN, 1 pint to 45 gallons of water; shovel the grain till thoroughly mixed and cover with bagging or blankets for from two to four hours, after which spread it out to dry.

Price by express, $1 / 2$ pint, $30 \mathrm{cts.;} 1$ pint, $50 \mathrm{cts.;} \mathrm{quart,} 85 \mathrm{ctm}$.; 2 Pts. $\$ 1.50$; gallon, $\$ 2.50$. Formalin cannot be sent bJ matl. 


\section{OATS}

\section{The Best Varieties For Fall Sowing}

\begin{abstract}
Advantages of Fall Sowing
For best results oats should have cool weather and plenty of moisture. Thcse conditions can be had in the fall, whereas there is

They provide grazing during the winter and early spring They provide grazing during the winte

Fall sown oats provide a cover crop and prevent washing and the leaching of valuable plant food from the soil.

They can be planted after corn and tobacco are cut, discing being the only preparation necessary.

Weather conditions in the fall are usually such that the land can be better prepared.

Spring is the farmer's busiest season, so that fall seeding interfercs
seecling.
\end{abstract}

\section{FULGHUM OATS}

Fulghum oats are not only the earliest of all the oats suitable for fall sowing, but are also one of the most productive varieties. They are ready to cut just ahead of wheat, so the harvesting of the two crops will not conflict; this advantage in favor of Fulghum oats should be borne in rind when arranging your work for next summer's harvest season. They of June, in plenty of time to follow vith a summer crop like cow pas, soja or soy beans, navy beans, millet, rorghum, buckwheat or an early valiety of corn.

Its productiveness, probably more than any of its other good qualities, has contributed to the wide popularity it has attained. We have reports of crops that yielded from 70 to 90 of crops that yielded from 70 to 90 bushels to the acre, a yicld that any other oat will find it hard to beat. full heads, fine plump grains and strong straw that stands about three feet high; the length of straw is well vorth considering if the oats are to be cut for hay.

In the several years we have handled Fulghum oats we do not recall a single instance of their being winter killed. We have unbounded faith in Fulghum oats, and do not hesitate to recommend them in the highest terms.

Prices fiuctuate. Present price, $\mathbf{p} \geqslant \mathbf{r}$ bushel \$1.CO; 5-bu. lots azd over, at $\$ 1.50$ per bushel.

I made a fine crop of Fulghum Oats that I estimate will be about 60 bushels to the
acre.-J. I. MOORING, Greene Co., N. C.

\section{Texas Red Rust-Proof Oats \\ In the South Atlantic States the} Texas Red Rust-Proof Oats have attained a prominent place in farming operations. This is particularly true in the coast region where other varieties have not proved altogether satisfactory, but where the Texas Red Rust-Proof seems to be especially well adapted to the light, sandy soil of that section. They are vigorous growers, robust and procluctive, and have heavy heads. They are also preferred for sowing on low grnunds and on land where other varieties seem inclined to rust.

These oats we procure direct from the growers in Texas, after which they are thornughly recleaned to remove light grains an, 11 fnreign matter and bring them up to our standard in point of quality.

Price fuctuates. Present price, per bushel $\$ 1.25 ; 5$-Nus. lots and over, $\$ 1.20$ per bus. oats for the South.

\section{What Oat to Sow}

If you can get them in during September or early in Octchcr we recommend the Virginia Cray Tinicr Oat-they yield hcary crops, but must be sown early. All the other varieties may be sown from September to November, your selcction dcpending on whether an early or late kind is wanted. The Fulghum is t'e earliest of all, and will come in before tre whcat harvest; Virginia Gray Winter is ready to cut just after wheat.

\section{Cat Soils and Fertilizer}

Oats will produce well on poorer soils than wheat and other grains, but pror soils should have an application of 200 to 300 pounds acid phosphate per acre. This has becn found profitab!e, whereas the use of a complete and more expensive fertilizer would not increase the crop sufficiently to show a profit on cost sow two bushels to the acre; cover 1 to 2 inches.

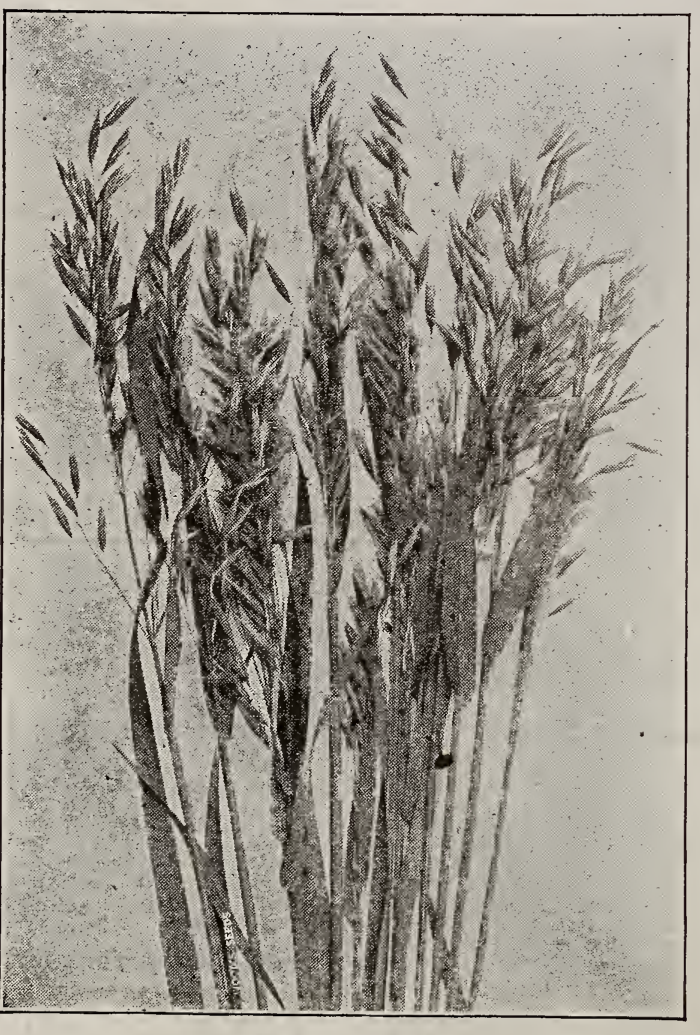

Fulghum Oats.

\section{VIRGINIA GRAY WINTER, or TURF OATS}

If you can get them in early, say in Septcmber, or certainly by the fir: week in Octobcr, we recommcnd the Virginia Gray Winter or Turf Oats for fall sowing. Probably the bezt reason for the wide popularity cf Vi:ginia Gray Winter Oats is thcir extreme hardiness, for there is no other treme cold at the at the Maryland Agricultural Experiment Station they proved the hardiest of all the varieties in their test Another good claim for their popularaccounts in part for the heavy yield one of the asricultural experiment stations reports that they stool mors than any ont tested. They have the ficin wer no ther other oat will weigh as much to the measurcd bushel; it is not unusual t have them weich 35 to 40 lbs. to th 3 wheat, allowing a nice arrangement of work at harvest time.

When sown early they make a good Trowth bofere wintor sets in and furris ex af fecting the vield of grain at harvest if not grazed too late. Their strong turfing and stooling characteristics give them advantares ove

ats for grazing purposes.

"In sections where timothy will not grow succcssfully, winter oats ma! an excellcnt suistitute. They will yield as much as timothy, the hay is easily cured, is relished by all $\mathrm{k}$.nd of stock, and is higher, "Maryland Agricultural Experiment Station.

Price fluctuates. Present price, per bushel $\$ 1 . C 0 ; 5-b u$. lots azit over, at $\$ 1.55$ per bushel.

\section{Bancroft Oais}

The Appler Oat is a winter rust-proof oat. It is earlier to mature and is hardier than the ordinary rust-proof, makes a strong quick-growing straw, bunchy heads and by Mr. Appler, of Harris County, Ga., who, by careful growing and selection, bred up this very superior oat. While originating in the State of Georgia, it has been grown to a considerable extent in other Southern States in recent years, and has proved to bo one of the most reliable winter rust-proof

Price fluctuates. Present price, per bushel $\$ 1.35$; 5-bu. lots and over, $\$ 1.30$ per bus.

Iike the Appler Oat, this is an improved train of Georgia Rust-Proof. It has prove? a most satisfactory oat, many grcwers claiming it to be the largest yiclder of the rust-proof varieties and $\pi$-ith more oats to the head, especially on lir?t, sandy soi's and on poor land. They stand up will, stool out well and have a good length of straw. Bancroft Oats are prime favorites with growers in the coast section of the snt:h Atlantic States, where they are viclding heavy crops and giving very general satisfaction

Price fluctuates. Present nrice, $p^{-r}$ bushel $\$ 1.50$; 5-bu. lots and ove:, \$:.J pe: kus. 


\section{SEED RYE}

Rye is a good crop to grow whether wanted for the grain, for for grazing, for green foed, for al, and for growing as a cover crop to prevent winter leaching of plant food from the land. It will thrive on a greater variety of soils than wheat, does well in dry seasons and on lands too thin, light and sandy to produce a profitable crop of wheat.

Rye malies an excellent fall, winter and early spring pasture for all kinds of stock, and, if the stock is taken off early, the can be had without-materially reducing the grain crop. herd of dairy cows may be well fed and giving a good flow of milk, yet when turned on a luxuriant growth of rye for a few lays the increase in milk will be astonishing.

For feeding green, rye will furnish green food earlier in the spring than most other forage plants.

As a winter cover crop rye will prevent the winter rains from leaching out of the soil expensive plant food that otherwise would be wasted; will furnish a crop that can be turned down in the spring in ample time for the planting of summer crops, in the spring in ample time for

Rve can be sown early or late, really adapting itself to your Rye can be sown early or late, really adaptier than wheat and ronvenience as to time of sowing. It is hardier thather comes on.
FACTS ABOUT RYE WORTH KNOWING

Rye will give a crop on land too light and poor for wheat. It will increase dairy stock.

for for earlier in the spring than other grains. Grazing it during the fall, winter and early spring does not materially reduce the grain yield.

It makes an excellent winter cover crop to prevent loss of plant foos.

It improves the mechanical condition of the soil when turned under.

It is hardier than wheat and can be sown later.

It can be sown at the last working of corn and cotton without additional preparation.

It makes a tougher straw than wheat and is better for bedaing.

On poor, light land early sowing is recommended in order that the crop may get well established before winter sets in.

Rye does not demand a complete fertilizer; the most successful farmers prefer 250 to $300 \mathrm{lbs}$. acid phosphate to the acre.

\section{ABRUZZI RYE}

\section{Extracts from Our Mail:}

"None of my small griin did well except Abruzzi Rye; bad weatber did not secm to hurt it.

' I+ beats all I ever tried.

"Abruzzi Rye made the best winter and spring grazing of anj thing $I$ ever planted.'

"I bnuobt $2 \mathrm{~T} / 2$ bushels Abruzzi Rye and thresbed out 95 bushels, it is first class.

"I have grown Abruxzi Rye three yeass. If common re was given me $I$ would plant Abruzzi even if it cost $\$ 7.50$ a bushel.

"It outgrew everytbing on the farm."

"I find it early and especially desirable for grazing."

"I pl Inted Abruzzi Rye on sandy land for hog pasture and it dil fine. After grazing it made fine heavy heads $3 \frac{1}{2}$ to 4 inches long.

"Abruzzi Rye is faster growth than Northern rye and en dajs to two weeks eurlier."

1 "My Abruzzi Rye is wonderful."

"I didn't plant the Abruzzi Rye till January, but got ome early grazing. and it now stands 5 fe.t higb on thin land."

Several years have elapsed since the United States Department of Agriculture introduced this rye from Italy. In the meantime it has had ample opportunity to prove its worth and adaptability to Southern soils and conditions, and it has certainly done it-the demand now is for Abruzzi Rye.

We could fill this page with extracts from our mails similar to those above telling what good crops had been grown on poor those above telling what good crops had been grown on poor, thin land, how much earler it is than ordinary rye; how well it had stood unfavorable weather conditions; what splendid grazin

it had furnished, and how much larger crops it had yielded. growers, especially in South Carolina, Georgia and further south where it gives a wonderful yield, stools out nicely, gives a quick vigorous growth with large, well filled heads that mature earlier than common rye.

\section{WINTER RYE}

This crop is used all over the South as a winter cover crop, for fall, winter and spring pasturage, early green food, and for green manuring as well as for grain. Rve is very hardy and will grow on on poorer land than other grain crops; makes good winter and spring pasture, and, if sown early enough, makes a good fall pasturage also. It is a good spring soiling crop, giving the earliest green feed, makes a fair quality of hay if cut before best of bedding for cattle and horses, and if carefully threshed. sells at high prices for collar making and other manufacturing purposes. It is also an excellent green cron for turning under in purposes. It also soil, as the early spring. While it does not and nitrogen to the soil, as the clovers do, it makes a good deal of humus, and thus improves the texture of worn nit soils. It ic verv extensivelv grown, and sucreeds well throughout the South. Rve can be very satisfactorilv sown at the last working of corn or cotton, no other preparation being necessarv, sn that the onlv cost for the crop will be the amount paid for the seeds: or it ran be sown bv itself from Julv to November. Snm at the rate of $11 \%$ bushels ner acre. over, \$2.50 no: bus. I-Aco i-cludez bacs.
If we may judge by the demand in former seasons and by the enthusiastic letters we have received from every section of the South, there will be an enormous demand this fall for Abruzzi Rye The reports received from our crop at the time this catalog goes to press indicate that we will be able to meet the demand, for we have arranged for the growing of the largert acreage planted since Abruzzi Rye was introduced. Notwithstanding. we urge vou to order early that you mav not be disappointed.
Bushel, $\$ 3.75 ;$ 5-bus. lots and over, $\$ 3.65$ per bushel. Price includes bags.

\section{PIEDMONT WINTER RYE}

For a number of years this rye has been grown in the Piermont section of Virginia and found particularly well adanted to the heavier lands of that section. However, its adaptability is confined to Piedmont Virginia for it has proved its value through out the westerly sections of Maryland, Virginia, North and S suth Carolina, in the heavier uplands of Georgia and in the mountain districts further west. To the heavier uplands, Pienmont Rve is as important as Abruzzi Rve is to the sections firther snuth and to the lighter lands nearer the sea mast. Price finctirates. Pr-cNo charge for bags.

\section{ROSEN PVE}

One of our farmer friends, writing about Rosen Rre, savs that from on not save it all because of a storm; another writes that from $11 / 4$ acres he harvested 35 bushels.

In our tests it proved later than other ryes, has thicker and heavier straw, grnws abnut 5 fapt hioh and stnols ont well. Present price: $\$ 2.60$ per bus.; 5-bus. lots, $\$ 2.50$ no: b: 


\section{Inoculating Cultures FOR LEGUMINOUS CROPS}

\section{They Increase Your Crops and Improve Your Land}

The advantages of inoculating leguminous crops like clovers, alfalfa, vetch, garden and field peas have been universally recog. nized. Legumes improve the condition of your soil and enrich it. When inoculated with the proper nitrogen-fixing bacteria, you not only have a greater assurance of a good stand, but legumes gather nitrogen, the most expensive of plant foods, from the air, convert it into available plant food, stimulating their own growth and enriching your soil for the benefit of succeeding crops.

No special knowledge, no expensive apparatus, is necessary in using either of the cultures offered below; the operation is perfectly simple, and full and clear directions are sent with every package.

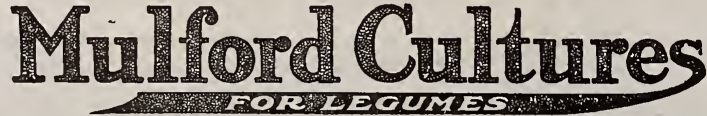

Mulford's Cultures are prepared and tested by experts in the laboratories of the $H$. K. Mulford Co. with the same scientific skill and precision as is exercised in the preparation of Mulford's antitoxins, serums, vaccines and their other medicinal products for human and veterinary uses. They have a world-wide reputation - y o u family physician can testify to the reliability of anything pu up by the $H$. K. Mulford Co

Each bottle of Mulford's Culture is guaranteed to contain a pure, active, vigorous cultur of nitrogen-fixing bacteria, of the proper strain for the legume indicated on the label, and in sufficient quantities to inoculate the required amount specified.

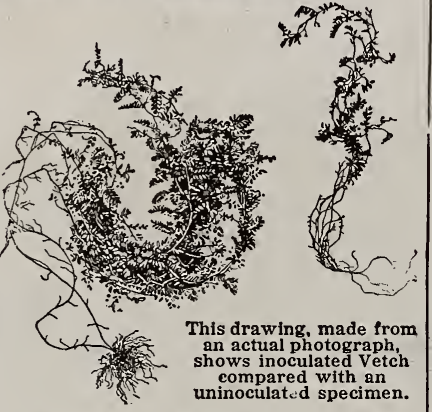

We can supply Irulford's Cultures for the following crops:

\section{ATFATFA}

RED CLOVER

Sapling Clover

CWIMST CLOVER

SWEFT CLOVER

ALSIKE CLOVFI

JUan Clover

WHITECIOVER

VETCH

We carry in stock inoculation for varieties in capitals; others are prepared as ordered.

Always state crop for which inoculation is wanted.

PRICE: 5-acre size ("a dollar an acre"), $\$ 5.00$; 1-acre size, $\$ 1.50 ; 1 / 4$-acre size, 50 cts.; small size (for garden beans, garden peas, lima beans and sweet peas only), $25 \mathrm{cts}$.

\section{BENEFITS OF INOCULATION}

Inoculated legumes take nitrogen from the air, resulting in faster growth, earlier maturity and larger crops.

Inoculated future crops get the surplus.

Inoculated legumes develop larger root systems; therefore reach the immense stores of potash and phosphorus in the sub-soil When the roots and stubble decay these elements are returned to the soil in a form available to future crops.

Inoculated legumes, by taking their nitrogen from the air, save the soil. When not inoculated they drain the soil of its nitrogen just the same as wheat or timothy or other non-leguminous plants.

Inoculated legumes contain more proteid matter than when not inoculated, greatly increasing their feeding value.

\section{STANDARD INOCULATING BACTERIA}

Easy to Apply $\rightarrow$ Just Moisten the Seeds Before Sowing-Complete Directions in Every Package.

Standard Bacteria is scientifically grown direct from the nodules, by
bacteriologists, who have made this their life work. The laboratories are fitted up with the latest and best equipment, and scientific accuracy is obtained. Each bottle is examined microscopically before shipment.

The bacteria is inoculated in improved extra sensitive media, enough food being included to feed the germs, Rubber corks are used, with glass air tubes to supply air to the bacteria and specially prepared cotton is packed in the tubes to filter out intruding mould and other germs. Amber bottles are used to exclude direct light.

This is the only method which permits absolute sterilization, and is in line with the most advanced knowledge in bacteriology.

We can supply Standard Inoculating Bacteria for the following crops:
AIFAIFA

RED CIOVER

CRIMSON CLOVER

AISTKE CIOVER

SWEET CLOVER

BURR CLOVER

JAPAN CI,OVER

SOY, or SOJA BEANS

GARDEN BEANS

Always state crop for which inoculation is wanted.

PRICE: 6-acre size, $\$ 3.00$; 4-acre size, $\$ 2.25$; 2-acre size, $\$ 1.40$;

1-acre size, $75 \mathrm{cts}$; garden size, $45 \mathrm{cts}$.

IIMA BEANS VEIVET BEANS

GARDEN PEAS

FIELD PEAS

COW PEAS

$\checkmark$ TTCF

PrinuTs

BEGGAR WFTD

SWGGAT WEET

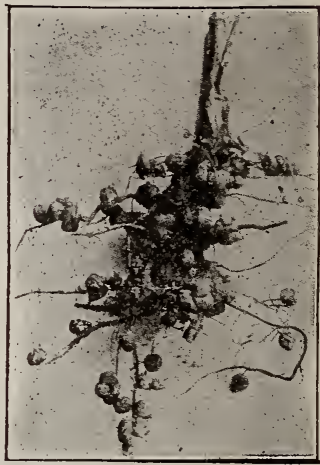

\section{FLOWER POTS AND SAUCERS}

Special Prices to Florists Using Iarge Quantities.

Charge will be made for packing at 25 cts. for orders amounting to $\$ 2.50$ or less. On larger orders add 10 per cent to amount of order. This barely covers the cost. We pack carefully, but will not be responsible for breakage.

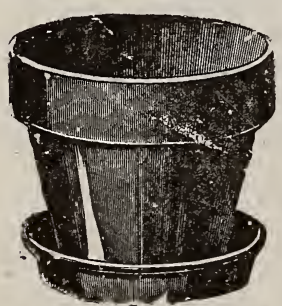
Diameter, Dozen. 2 -inch $21 / 4$-inch $21 / 2$-inch 3 -inch 5-inch 6 -inch

7 -inch 8-inch 10 -inch 12 -inch

BUIB DISHES-For growing bulbs in water among pebbles. 6 -inch, 40 cts. each; $\$ 4.50$ per dozen. 8 -inch, 50 cts. each; $\$ 5.75$ per dozen.

BUIB HOIDERS-6-inch, 25 cts. each; 8-inch, 35 cts each.
Per 100. Per 1,000 .

$\$ 0.15$

.20

.30

.40

1.10

Fach.

.20

.25

.90

$\$ 1.20$

1.40

1.60

3.00

6.00

Dozen.

1.80

2.40

$\mathbf{4 . 7 5}$

$\$ 10.00$

12.00

18.00

26.00

50.00
65.00

Per 100.

14.00

18.00

37.50

(1)

Diameter.
5 -inch
6 -inch
7 -inch
8 -inch
10 -inch
12 -inch

$\begin{array}{rr}\text { Fach. } & \text { Dozen. } \\ \$ 0.04 & \$ 0.40 \\ .06 & .50 \\ .08 & .75 \\ .10 & 1.00 \\ .15 & 1.60 \\ .22 & 2.40\end{array}$

SHAILOW POTS

Similar to the ordinary flower pot, but shallower, being only $41 / 2$ to 5 inches deep. Just the thing for bulbs, ferns, etc.
Diameter
6 -inch
7 -inch
8 -inch
10 -inch
Fach.
$\$ 0.12$
.20
.25
.50
.50
1.00
$\$ 1.25$
2.00
2.50
5.00
Dozen.
10.00 12 -inch

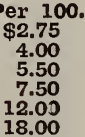
100 4.00 7.50 2.00 


\section{WOOD'S GARDEN SEEDS FOR FALL PLANTING}

\section{"POSTPAID" and "BY EXPRESS"}

"Postpaid" Means that seeds so quoted in any quantity postoffice in the United States. At postpaid prices we will deliver by express if you prefer; it is safer.

\section{For Complete Descriptions of Varieties see Our Annual Catalog}

\section{ASPARAGUS ROOTS}

CUITURE.-Dig or plow out a trench 15 to 18 inches deep, put in plenty of well-rotted manure, covering it with a few inches of soil. In November set the roots $1 \frac{1}{2}$ to 2 feet apart and cover with 4 ins. of soil. In the fall, cut off and burn the top growth, plow or throw down the earth and give a good application of stable manure. Early in the spring fork this in and apply ground animal bone or kainit and as the asparagus beoins to grow, earth up to blanch the stalks as they grow. Do not continue cutting too long, as this exhausts the plants. 100 roots plants about $15 \times 50$ feet; 5,000 to 7,000 will plant an acre. Orders booked now for shipment after November 15 th.

PAIMETTO.-Two-year-old roots, 50 for $70 \mathrm{cts.;} \$ 1.25$ per 100 , postpaid. By express, $\$ 1.00$ per $100 ; 500$ for $\$ 2.75 ; \$ 5.00$ per 1,000 .

CONOVIR'S COIOSSAI. - Two-year-old roots, 50 for 65 cts.;
$\$ 1.15$ per 100, postpaid. By express, $90 \mathrm{cts}$. per 100; 500 for \begin{tabular}{l}
$\$ 2.50 ; \$ 4.50$ per 1,000 . \\
\hline
\end{tabular}

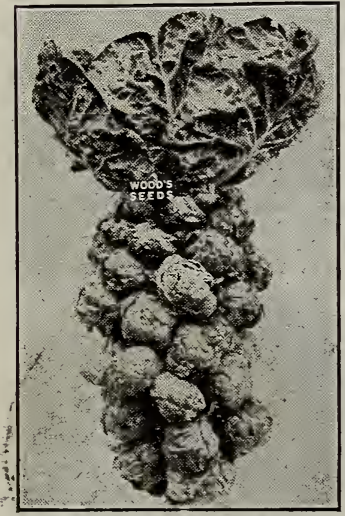

Brussels Sprouts.

\section{See page 29 for \\ ASPARAGUS BUNCHERS ASPARAGUS KNIVIS JUTE STRING for tying vegetable bunches, etc.}

BROCCOLI - Sa similar to but taller, the heads more divided, and will stand greater extremes of temperature. Cultivate like Cauliflower. One ounce produces about 2,000 plants. Pkt. 5 cts.; oz. 35 cts.; 1/41b. \$1;

BRUSSELS PERFIECTION. SPROUTS tout hed by to cauliflower in they are equal to cauliflower in flavor and as great a delicacy. Pkt. 5 cts.; 02. postpaid. By express, $\$ 2.65$ per lb.

"By Express" Means that the purchaser pays the cost of
zone, it is cheaper to ship by express than by parcel post.

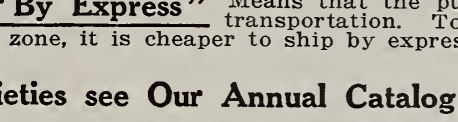

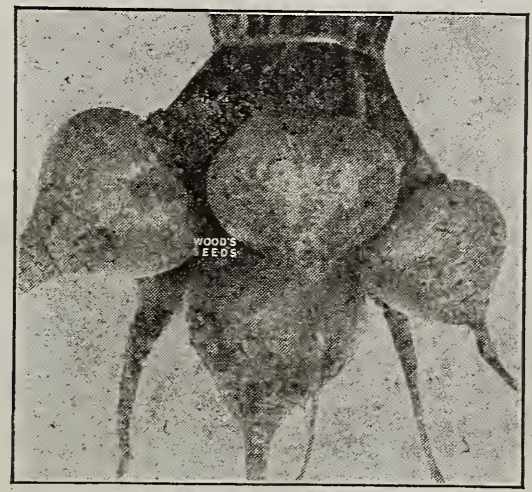

Improved Farly Blood Turnip Beet.

\section{GARDEN BEETS}

For fall and winter use, plant in June or July in rows 15 inches apart, thinning out to 4 inches in the row further South plantings may be made as late as September in the open ground, after which they should be planted in hot-beds for transplanting. Soak the seeds from 24 to 36 hours before planting. One ounce
will sow 50 feet; 6 to 8 lbs., one acre.

-By Mail, Postpaid press

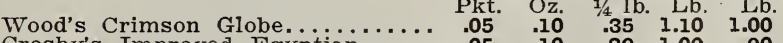

Crosby's Improved Egyptian......

Improved Early Blood Turnip....

Extra Early Egyptian...........

Detroit Dark Red..............

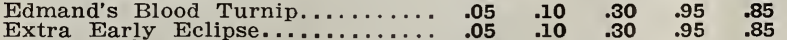

Long Smooth Blood.............

\section{GARDEN BEANS or SNAPS}

Beans should be planted every two weeks until August 15th for a succession. Further south they may be planted even later. Allow seven or eight weeks before frost in which to make the crop. It the garden, plant 2 inches deep, 3 inches apart in rows GREEN PODDED VARIETIES

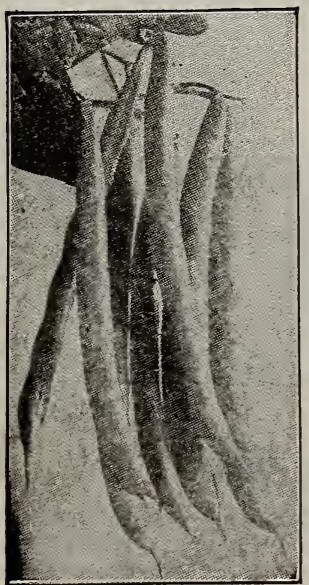

All Varieties, 10 cts. per pkt. postpaid.

Whar

$\begin{array}{lllll} & .3 \ldots \ldots & .30 & .55 & 1.20\end{array}$

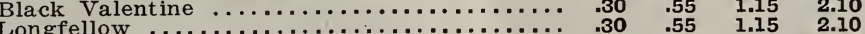

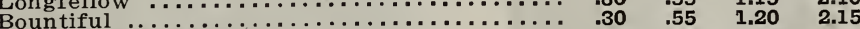

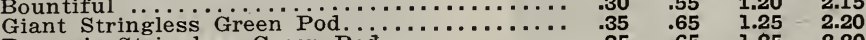

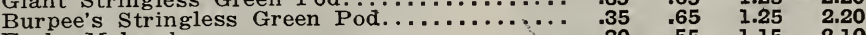

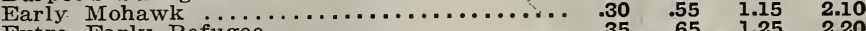

Extra Early Refugee.................... $.35 \quad .65 \quad 1.25 \quad 2.20$

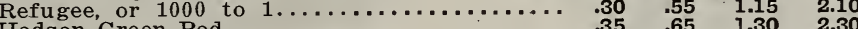

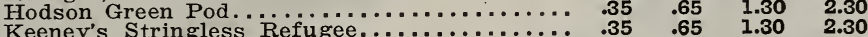

YELLOW OR WAX PODDED VARIETIES

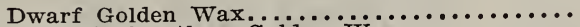

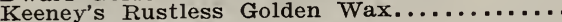

Dwarf Black Wax

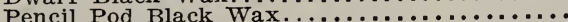

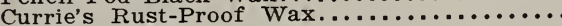

Hodson Wax

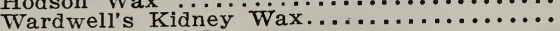

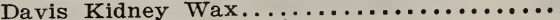

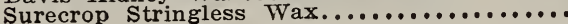

$\begin{array}{cccc}\text { Lb. } & \text { Mail } & \text { Postpaid. } \\ \text { Lb. } & \text { 1b. } & 10 \text { lb. } \\ .35 & .65 & 1.35 & 2.35 \\ .35 & .65 & 1.40 & 2.40 \\ .35 & .65 & 1.35 & 2.35 \\ .35 & .65 & 1.40 & 2.40 \\ .35 & .65 & 1.35 & 2.35 \\ .35 & .65 & 1.40 & 2.40 \\ .40 & .75 & 1.50 & 2.70 \\ .35 & .65 & 1.40 & 2.50 \\ .35 & .65 & 1.40 & 2.40\end{array}$

Lb.
.25
.25
.25
.25
.30
.30
.25
.30
.25
.30
.30

$\begin{array}{ll}\text { y } & \text { Freigh } \\ 2 \text { 1b. } & 5 \\ .45 & 1 . \\ .45 & 1.00 \\ .45 & 1 . \\ .45 & 1 . \\ .55 & 1 . \\ .55 & 1 . \\ .45 & 1.00 \\ .55 & 1.00 \\ .45 & 1.00 \\ .55 & 1.15 \\ .55 & 1.15\end{array}$

ght or
$5 \mathrm{lb}$.
1.05
1.00
1.00
1.05
1.10
1.10
1.00
1.10
1.00
1.15
1.15

Expre
$101 \mathrm{~b}$
1.90
1.85
1.85
1.90
1.95
1.95
1.85
1.95
1.85
2.05

\begin{tabular}{lrrrr}
\multicolumn{1}{l}{ By } & \multicolumn{3}{c}{ Freight } & \multicolumn{3}{c}{ Express. } \\
Lb. & 2 lb. & 5 lb. & $101 \mathrm{lb}$ & $100 \mathrm{lb}$. \\
.30 & .55 & 1.20 & 2.10 & 18.50 \\
.30 & .55 & 1.25 & 2.15 & 20.00 \\
.30 & .55 & 1.20 & 2.10 & 19.50 \\
.30 & .55 & 1.25 & 2.15 & 20.00 \\
.30 & .55 & 1.20 & 2.10 & 19.50 \\
.30 & .55 & 1.25 & 2.15 & 20.00 \\
.35 & .65 & 1.35 & 2.45 & 23.00 \\
.30 & .55 & 1.25 & 2.25 & 21.00 \\
.30 & .55 & 1.25 & 2.15, & 20.00
\end{tabular}

7.50

17.00

17.50

18.00

18.00

18.00

17.00

19.00

19.00 


\section{WOOD'S CABBAGE SEEDS FOR FALL PLANTING}

CUITURE,-For fall and early spring setting, sow from the end of September till the first of January. November and December sowings should be made in cold-frames or hot-beds for protection during the winter. Plants trom early fall sowings can be set out the end of October or during November to head up early in the spring. Plants that are wintered over should be set out in February, March or April, as early as the weather will permit. Set the plants 18 inches apart in rows $2 \frac{1}{2}$ to 3 feet apart, running the rows east and west and setting the plants on the north side of the ridge to prevent, as much as possible, the frequent freezing and thawing so injurious to cabbage. Requires a good, rich soil, plenty of moisture and a highly ammoniated fertilizer, also frequent deep working.

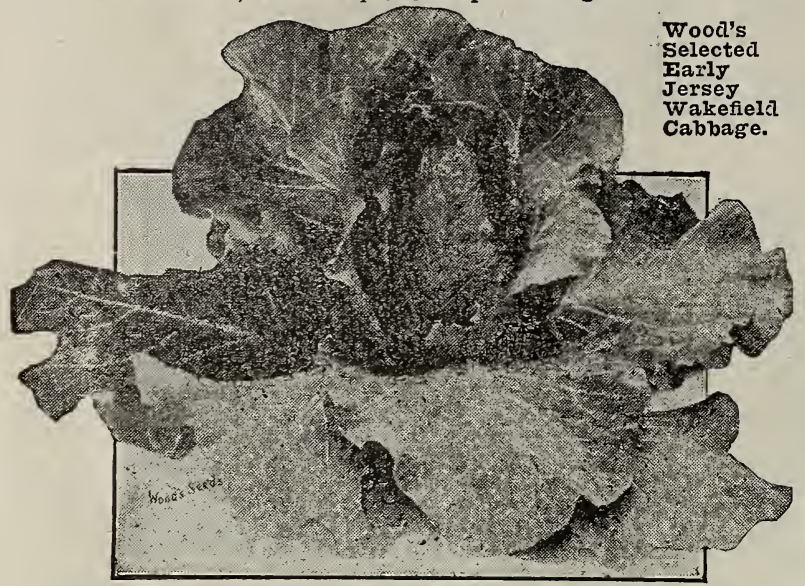

\section{Wood's Selected Early Jersey Wakefield}

Long continued care and critical selection have resulted in as pure a strain as it is possible to obtain; sureness to head an regularity in growth have placed our Wakefield at the top in popularity with our Solithern growers. We have no fear of praising it too highly-it is a thoroughbred strain. Makes a compact solid head with fer outside leaves, permitting of close planting. Very hardy, resisting cold and unfavorable conditions, thus insuring the greatest likelihood of proftable and satisfactory results. Plst. 10 cts.; 0z. 45 cts.; 1/41b. $\$ 1.40 ; 1 \mathrm{~b} . \$ 5.00$ postpaid̃.

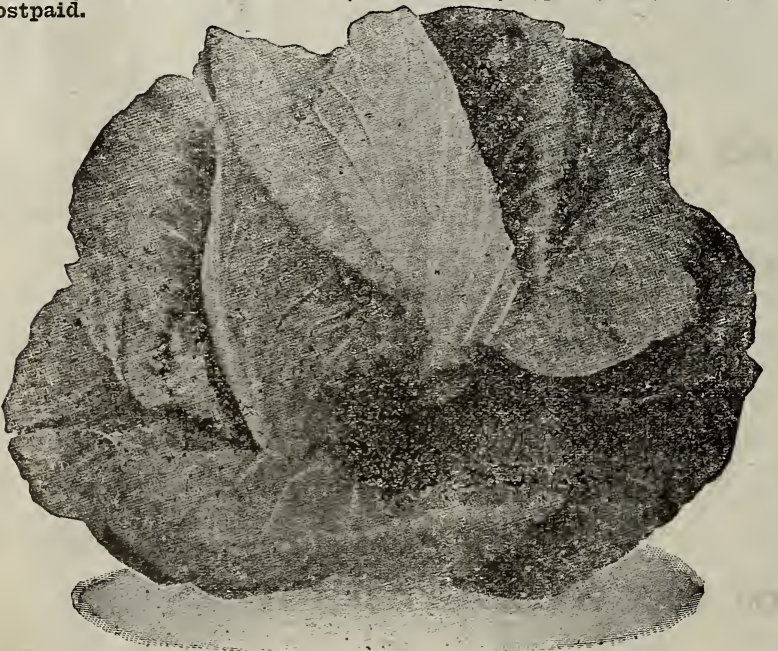

Wood's Extra Early, The Earliest of All

The earliest cabbage in cultivation and in every way one of the most desirable extra early varieties. Larger than the Wakefield; not quite as solid, but fully a weels earlier. The quality is rood, has few loose leaves, and nearly every plant forms a

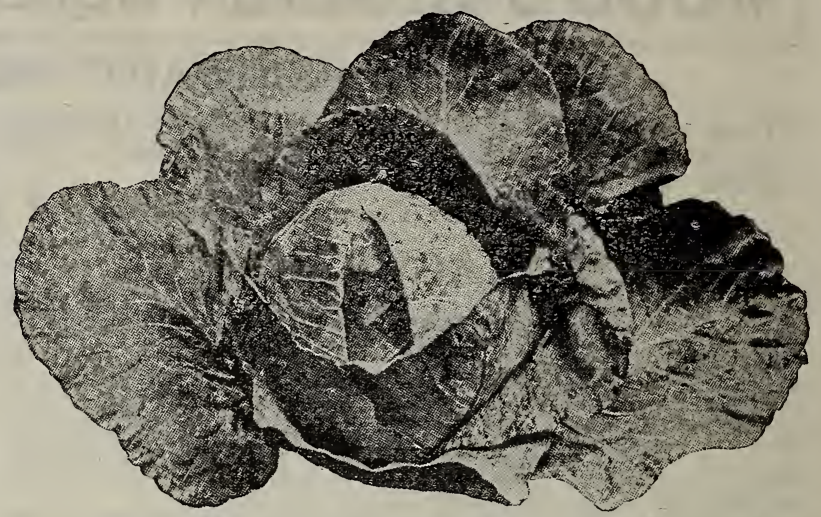

\section{Wood's Charleston Wakefield}

All that we say about the purity and excellence of our Jersey Wakefield is equally true of our Charleston Wakefield-it is as pure and true a strain as careful selection can make it. A pure and true a strain as careful selection can make it. A solid. Exceedingly hardy, and on account of its earliness and size is deservedly popular, both with large market growers an' postpaid.

Early Winnigstadt -A first-class medium early pointed cabgood size, very hard and of excellent quality. Pirt. $10 \mathrm{cts.;}$ oz. 40 cts.; 1/41b. $\$ 1.25$; 1b. $\$ 4.50$ postpaid.

Copenhagen Market -The earliest large, flat-headed cabfield. Remarkably large, averaging 10 pounds, so solid as to allow more plants per acre than with other kinds. Earliness, uniform ripening, compact solid growth and size are its principal charácteristics. Our seeds are grown by the originator in Denmark and imported direct. $\$ 2.25$; 1b. $\$ 8.00$ postpaid.

Solid South - A magnificent cabtake special pride, and which we cannot recommend too highly. Resembles the Early Summer, but is earlier, targer, more uniform, has fewer outside leaves, and is less liable to run to seed when sown in the fall. Pkt. 10 cts.; $\$ 2.00$ postpaid.

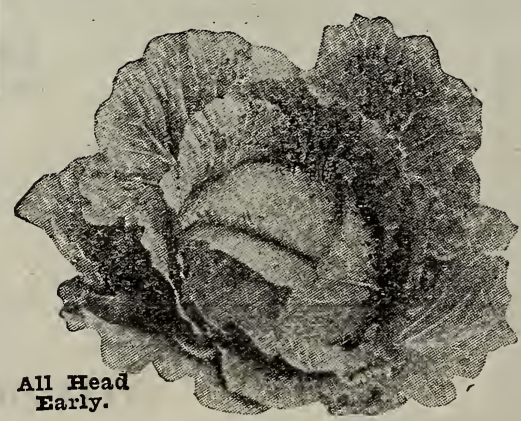

Solid South.

All Head Early

-A t h or ou ghbred sort, especially recommended on account of its uniform size and shape and reliability for heading. M a k s a deep, flat head, solid and uniform in color, shape and size. In tenderpassed. Its compactness allows it to be planted closer a nd will yield more heads to the acre than the varieties of a more spreading habit: Prt. $1 / 41$ b. $\$ 1.40$; $1 \mathrm{~b}$. $\$ 5.00$.

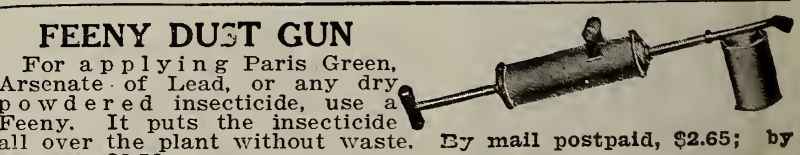
Feeny. It puts the insecticide express, $\$ 2.50$. 


\section{Henderson's Early}

Summer -Although inago, it still holds its place as an ideal second early. Forms large, flat, round, solid heads weighing 8 to $10 \mathrm{lbs}$., and is a sure and reliable header. Comes in ble header. Comes in Early Jersey Wakefield but is larger. Pkt. 10 cts.; oz. 40 cts.; $1 / 41 \mathrm{lb}$. $\$ 1.30 ;$ ib. $\$ 4.75$ postpaid.

All Seasons $-\mathrm{He}$ a d s and round, often nearly spherical, but usually somewhat flattened. Is very solid, and of the

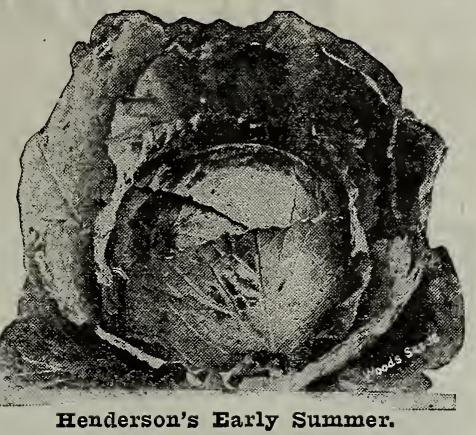

Fenderson's Farly Summer. best quality, keeping as well as the winter sorts; sure-heading. Plst. 10 cts.; oz. 45 cts.; 1/41b. $\$ 1.40 ; 1 \mathrm{~b}$. $\$ 5.00$ postpaid.

Early Drumhead - Very popular throughout the South and most excellent, sure-heading second early cabbage of as fine quality as anyone could wish. The heads are large, flattened on top solid crisp and tender. Especially adapted for the home garden. Pkt. 10 cts.; oz. 40 cts.; 1/41b. \$1.30; 1b. \$4.75 postpaid.

Henderson's Euccession -A splendid sort whether grown the late crop, and keeps well for winter use. A little later than Early Summer, but much larger. Heads deep and solid, of handsome color and of the finest quality. The heads become solid before they are fully matured. Pkt. 10 cts.; oz. 45 cts.; $1 / 41 \mathrm{~b}$. $\$ 1.40 ; 1 \mathrm{~b}$. $\$ 5.00$ postpaid.

Mixed Cabbages $-A$ splendid mixture of all the early cabfor the home garden and for plant growers. Pkt. io cts.; oz. 40 ctr.; 1/1b. $\$ 1.30$; lb. $\$ 4.75$ postpaid; 5-1b. lots, $\$ 4.50$ per 1b. Special price in larger lots.

Chinese Petsai $-A$ wonderful salad plant, somewhat like of most excellent salad. Sow in July or August, transplanting 18 inches apart in $21 \%$-foot rows. Pkt. 5 cts.; oz. 25 cts.; $1 / 41 \mathrm{~b}$. 85 cts.; 1b. $\$ 3.00$ postpaid.

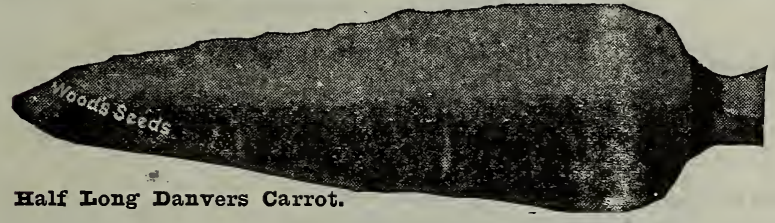

\section{CARROT}

For winter use plant in July or August in a rich deeply-worked soil, $1 / 2$ inch deep in drills 12 inches apart, and thin out to 3 or 4 ins. apart. Germinates more freely if soaked for several hours before sowing. Sow a few radish seeds in the same rowthey germinate more quickly and serve to mark the rows. To put away for winter, cut off the tops to within an inch of the crown and pack in sand in the cellar, or pit them outdoors and cover with straw and 6 or 8 ins. of earth to prevent freezing. In this way they may be kept all winter.

By ExBy Mail, Postpaid $\longrightarrow$ press. Scarlet Itorn............... . .05 .10 . $30 \quad .95 \quad .85$

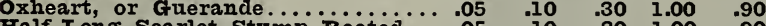
Falf-Iong Scarlet Stump Rooted...

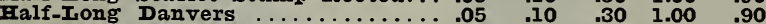
Wood's Scarlet Intermediate.............. Wood's scarlet Intermediate.........05 $\quad .10 \quad .35 \quad 1.10 \quad 1.00$

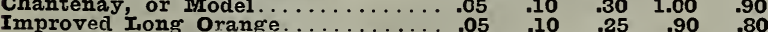

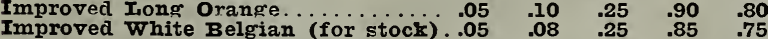
Iarge Yellow Belgian (for stock) .....05

CELERY $\overbrace{\text { Pkt. Oz. } 1 / 41 \mathrm{~b} . \mathrm{Lb} .}$ Golden Self-Blanching (French grown) .......10 $.65 \quad 2.25 \quad 8.00$ Improved white Plume....................

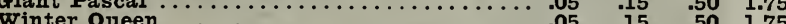

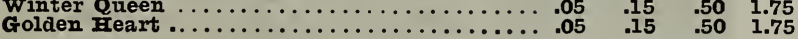

\section{EGG PLANT}

New Tork Improved Purple..............10

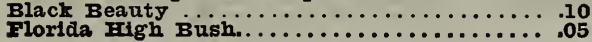
$.35 \quad 1.00 \quad 3.50$

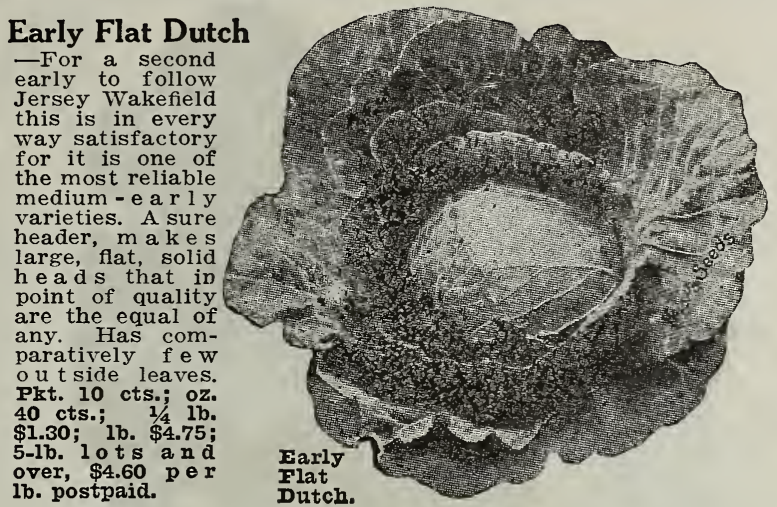

\section{LATE CABBAGE}

North Carolina Buncombe.

By Mail, Postpaid.

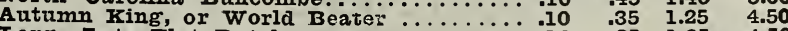

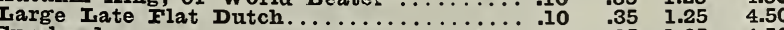

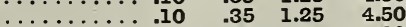

Danish Bailhead or Hollander...........

Iarge Iate Drumhead...................

Wood's Prize Il Iead Iate Fiat Dutch........... $10 \quad .45 \quad 1.40 \quad 5.00$

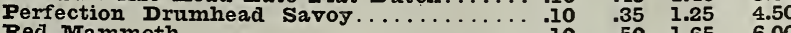

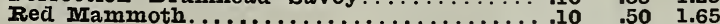

CABBAGE PIANTS.-Late varieties can be had up to September 15th. 50 cts. per 100, postpaid. By express, 40 cts. per 100; $\$ 3.50$ per 1,000. Early varieties during October and
November, 50 cts. per 100 , postpaid. By express, $40 \mathrm{cts}$. per November, 50 cts. per
ino: $\$ 3.50$ per 1,000 .

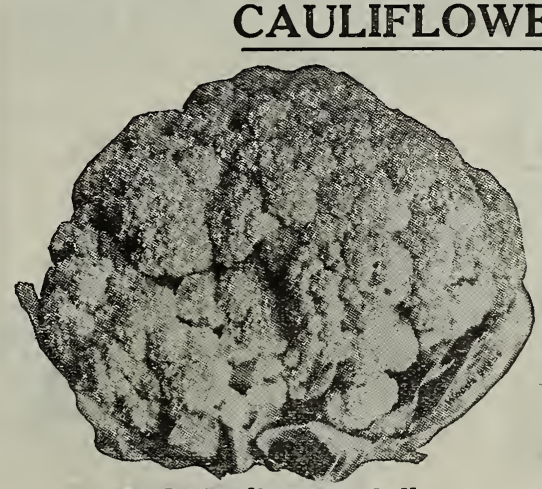

Wood's Earliest Snowball.

Cauliflower requires the s a m e treatment a $\mathrm{n}$ d cultivation as a d a d culeas hardy, either in reweather or to cold weather, but wh e r they can be watere during dry spells or protected during the late fall a $\mathrm{n}$ d winter isfactory crop. Can be sown in June, July and August for heading up during the fall, frames in the fall and set out early in the
spring. We supply $1 / 2$ ounces Caulifiower at the ounce rates.

Wood's Earliest Snowball -There is no better cauliflowe strain is as fine as head, but a remarkably sure header, making large, solid, perfect, pure white heads of the finest quality. As well adapter for forcing as for growing out of doors.
cts.; oz. $\$ 2.50$; 1/41b. $\$ 9.00$; 1b. $\$ 35.00$.

Extra Early Dwarf Erfurt -A first-class cauliflower rankduces large, white, close, firm heads of fine quality. It is extra early and a sure header. Pkt. 15 cts.; 1/40z. $60 \mathrm{cts}$. oz. $\$ 2.25$; $1 / 41 \mathrm{~b}$. $\$ 8.00$; 1b. $\$ 30.00$.

Veitch's Autumn Giant -A valuable late variety, admiraThe hears are large and white adapted for growing in the fall. Pkt. 10 cts.; oz. 45 cts.; $1 / 41 \mathrm{lb}$. $\$ 1.65$; 1b. $\$ 6.00$ postpaid.

CAUIIFIOWER RIANTS.-BY mail, postpaid, $\$ 1.10$ per 100 By express, $\$ 1.00$ per $100 ; \$ 8.00$ per 1,000 .

Look on Page 30 -There you will find a lot of garden tools get the most out of your garden. 


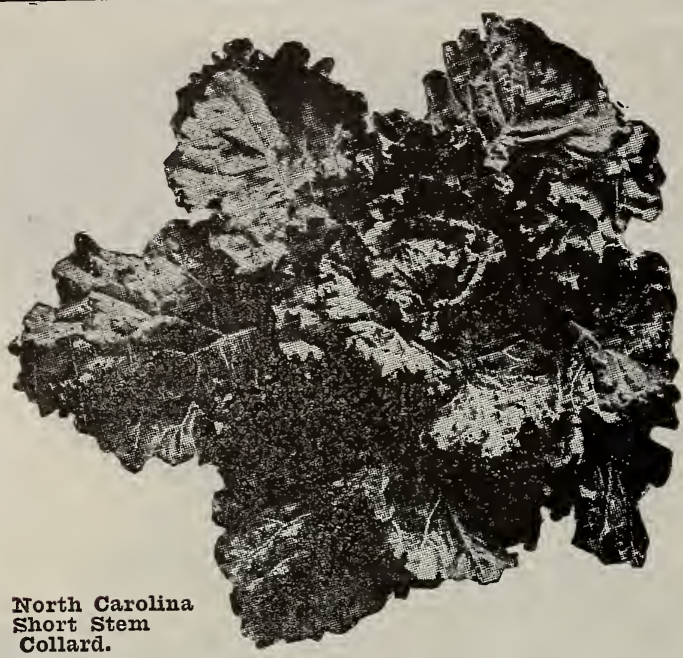

\section{COLLARDS}

One of the most popular Southern vegetables. Largely used in in place gromost winter and well into the spring. For late crop, plant in June, July and August, transplant a foot apart in the row and cultivate frequently.

SHORT STEMr.-Has large spreading leaves and short stem. Very hardy; withstands drought and cold. Flavor and quality of the best. Pkt. 5 cts.j. 5 per lb. 40 cts.; 1b. $\$ 1.35$ postpaid. By express, $\$ 1.25$ per 1 cord because INIPROVID GEORGIA WHITE.-Called cabage collard to a cabof its close bunching habit and general resemblance to a cabbage. Extremely hardy and grows on the poorest soils. As $30 \mathrm{cts}$. ; 1b. $\$ 1.00$ postpaid. By express, $90 \mathrm{cts}$. per $1 \mathrm{~b}$.

TUU collard that has been grown for generations in the South. 1b. 90 cts. postpaid. By express, 80 cts. per 1b.

\section{CORN SALAD}

-A most desirable salad. Can be used like lettuce or cooked like spinach. It has not been grown South because its merits are not generally known. August and September are the use during the fall. Sow in shallow drills about 1 foot apart. Pkt. 5 cts.; oz. 15 cts.; $1 / 41$ b. 45 cts.; 1b. $\$ 1.60$ $\$ 1.50$ per 1b.

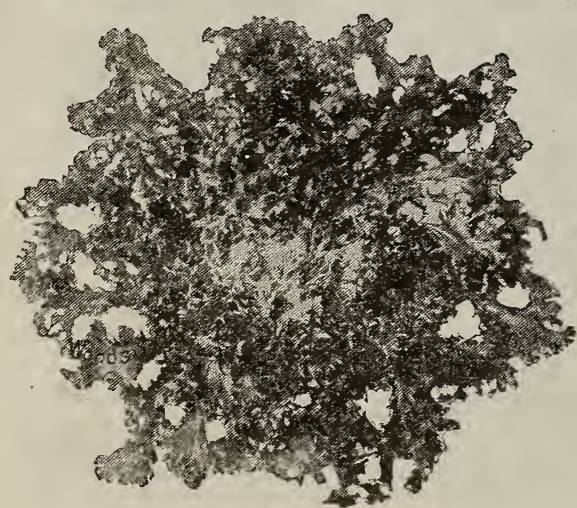

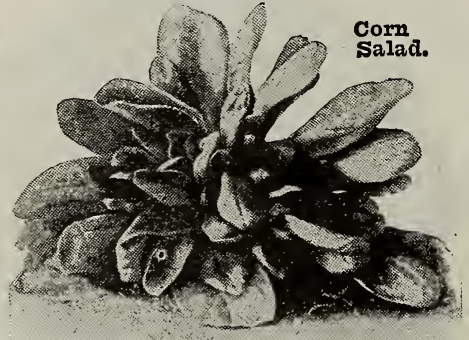

ENDIVE

Culture. - Sow in $\mathrm{Augut}$ in 18-inch drills and thin out to one foot apart. When nearly grown, tie up $t h e$ outer leaves to blanch the heart. In dry seasons give plenty of water.

GREFN CURIED. -

Pkt. 5 cts.; Oz. 15 cts.; $1 \frac{1 / 41 \mathrm{~b} .}{40}$ ct,s.; By express, $\$ 1.25$ per $1 \mathrm{~b}$.

WHITE CURIFD. Pkt. 5 cts.; $0 z$. 15 cts.; $\$ 1 / 41$ b. 40 cts.; By $\$ 1.35$ postpaid. per lb.

\section{KALE or BORECOLE}

Culture.-The Siberian and Scotch are the popular sorts for fall sowing. Sow from Aug. 15 th to Oct. 15 th, either broadcast or in drills 18 inches apart, and give some cultivation, and they will yield greens throughout the winter. Spring or Smooth Kale may be sown either in the fall or spring, making greens earlier than the winter sorts, but not of as fine quality. Sow $8 \mathrm{lbs}$. per acre broadcast, 4 to $5 \mathrm{lbs}$. in drills.

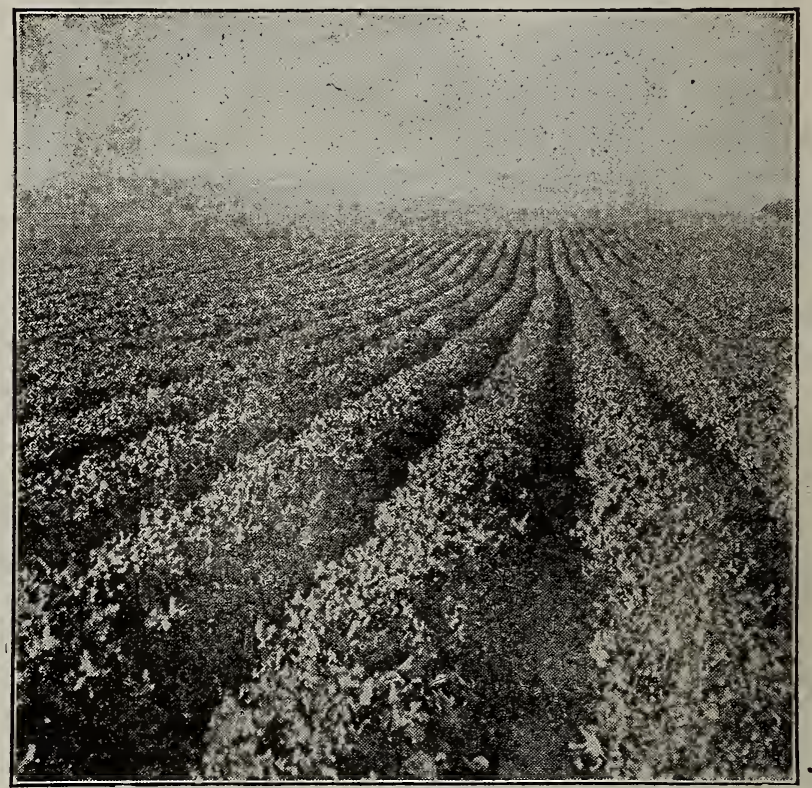

View of Our seed Crop of Siberian Trale.

Dwarf Curled Scotch or Norfolk - The most beautii $x 1$ valarge growth; leaves of a bright, deep green color, exquisitely curled and crimped. It is very hardy and makes large vields. Pkt. 5 cts.; oz. 15 cts.; 1/4 Ib. 50 cts.; 1b. $\$ 1.85$ postpaid. By express, $\$ 1.75$ per $1 \mathrm{~b}$.

Early Curled Siberian (Blue Kale) -One of the most popuse and home market. The plant is dwarf, spreading and very liardy, standing the winter without protection. The leaves are green, slightly tinted with purple and of superior quality.

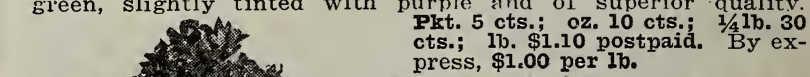
press, $\$ 1.00$ per $1 \mathrm{~b}$.

\section{Spring or Smooth Kale}

- Largely sown in the fall for cutting during the winter and spring before the winter kinds are ready. Pkt. 5 cts.; $1 / 41 \mathrm{lb} .10$ cts.; 1b. 35 cts. postpaid. ${ }^{\text {By }}$. for $\$ 1.00$.

\section{PARSLEY}

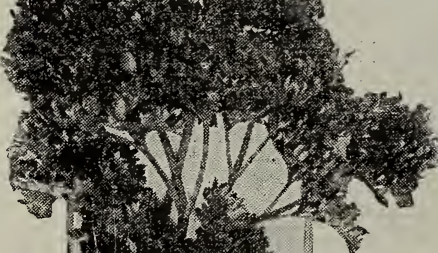

For spring use sow in September or October and give slight protection, or sow in cold-frame or hotbed for winter use. Seeds 12 hours before sowing.

CHAMIPION MIOSS CURIID

-Beautifully curled. Best for garnishing and flavoring; also attractive for edges of walks and beds. Plt. $5 \mathrm{cts}$; $0 z_{0} 10 \mathrm{cts}$; 1/4lb. 25 cts.; 1b. 90 cts. postpaid. By express, 80 cts. per $1 \mathrm{lb}$.

PIAIN or SINGIE. - Stronger flavored than the curled; very hardy. 25 cts.; 1b. 90 cts. postpaid. By express, 80 cts. per 1b. 


\section{LETTUCE}

CUITURE.-Lettuce is easy to grow, but requires rich, moist soil, clean and thorough cultivation, and plenty of water to give it that quick growth on which depends its tenderness and flavor. Sow in July or August, transplant as soon as ready, and they will head up late in the fall. For later use transplant to coldframes, protect during severe spells, and they will head up during November and December. Plant the hardy varieties, like during November and December. Plant the hardy varieties, like wide later. Protect with straw or litter, and they will stand the side later. Protect with straw or litter, and they can be transplanted to cold-frames or hot-beds to head up during the winter. Wood's Improved Big Boston is the best for early fall planting; Wood's Cabbage is better for later planting, as it is hardier and stands more cold weather. One ounce will produce about 1,500 plants.

\section{Wood's Cabbage Lettuce}

HARDIEST AND BEST IFTTUCE FOR OUTDOOR GROWING

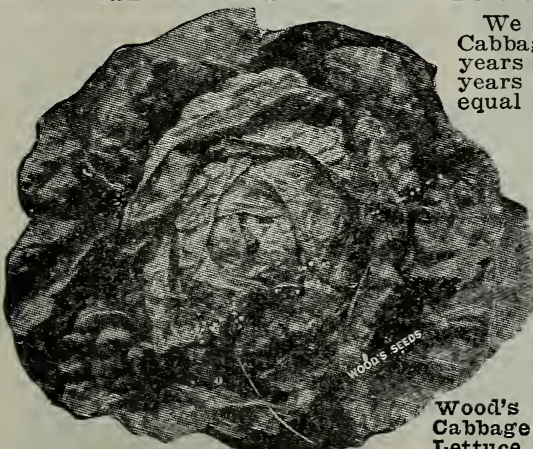

introduced $W$ o d's Lettuce thirty-six years ago, and in all these equal for fall sowing.

We do not hesitate to say it is the best wintering o $\mathrm{u} t$ doors in the $\mathrm{S}$ o $\mathrm{uth}$. No lettuce will stand cold weather better. Makes a fine, large firm, well - blanched head of excellent quality a nd sweet 5 cts. $1 / 41$ b. 40 cts.; 1b. $\$ 1.40$ postpaid. $R$ Cabbage express $\$ 1.30$ per $1 \mathrm{~b}$. Iettuce. over, $\$ 1.20$ per $1 \mathrm{~b}$.

May King - Extra fine for Large, round, solid heads, 6 to 7 inches in diameter, with broad, light green outer leaves firmly folded. Grown outdoors, it is extremely early; for forcing blanches to a rich golden blanches to a rich golden all-round first early lettuce. Pkt. 5 cts.; oz. 15 postpaid. By express, per 1b. $\$ 1.00$.

Crisp-as-Ice -A very suand home market lettur so crisp, tender and brittle

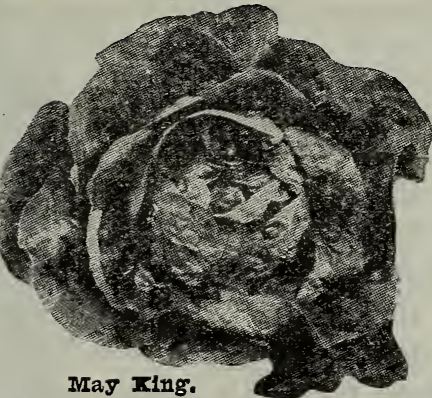

as to fully justify the name. The heads are hard, with rich creamy-yellow fiearts. Pkt. 5 cts.; oz. 15 cts.; 1/41b. 45 cts.; 1b. $\$ 1.60$ postyaid. By express, $\$ 1.50$ per $1 b$.

Deacon -One of the best summer cabbage lettuces for home use; it is sure heading and reliable; quality excellent

slow to run to seed. Pkt. 5 cts.; oz. 15 cts.; $1 / 41 \mathrm{~b} .35$ cts.; 1b. $\$ 1.10$ postpaid. By express, $\$ 1.00$ per $1 \mathrm{~b}$

California Cream Butter - Does well everywhere and in all seasons. Good shipper, very hardy
and especially recommended for California $\quad \begin{aligned} & \text { outdoor growing. One of the most } \\ & \text { buttery flavored and best in quality. }\end{aligned}$ Butter. $\quad$ Pkt. 5 cts.; oz. 15 cts.; 1/41b. Butter. 35 cts.; 1b. \$1.10 postpaid. $\mathrm{By}$

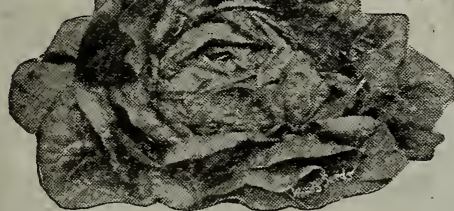

Early Prizehead of $\mathrm{n}$ e b e st f or home - garden, orming a large, 1 oos head: exceedingly tender crisp and sweet. Fine for home use. Pkt. 5 cts. oz. 15 cts.; $1 / 41 \mathrm{lb}$. 35 cts.; press, $\$ 1.00$ per $1 \mathrm{~b}$.

Cos, Romaine or Celery Lettuce - Has no e q u a 1 for conical heads, which if tied up, blanch pure white and long, heads as crisp as celery stalks. Pkt. 5 cts.; oz. 15 cts.; 1/41b. $40 \mathrm{cts}$; $1 \mathrm{~b}$. $\$ 1.35$ postpaid. By express, $\$ 1.25$ per lb.

\section{Wood's Improved Big Boston}

\section{THF TFTTUCF FOR COTD FRAMTS}

Too much praise cannot be given our grand strain of this splendid lettuce. It has steadily gained in popularity until now it is more exten si ve 1 y varieties except o $u r$ Wood's Cabbage Lettuce. May be grown in the open ground for summer and fall use, or in frames under canvas, a $n$ d always $m$ a kes large, with thoroughly blanched hearts, crisp and tender, white and sweet We a n ot recommend too highly our splendid strain of this most excellent variety. It gives the best of satisfaction

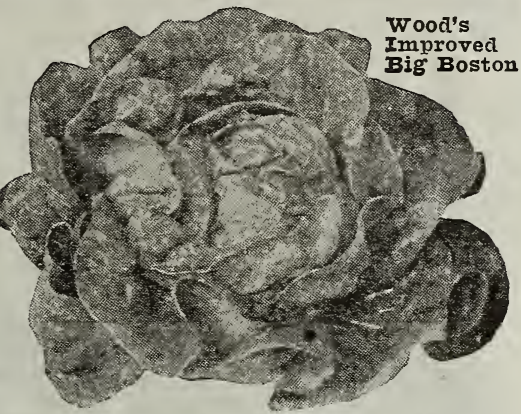

ditions. Pkt. 5 cts.; 35 cts.; 1b. $\$ 1.20$ postpaid. By express, $\$ 1.10$ per 1b.; 5-1b. lots and over, $\$ 1.00$ per $1 \mathrm{~b}$.

Grand Rapids - A mong the curled

notter for forcing, and it does splen-

didly outdoors when

does not form heads,

but $\mathrm{makes}$ a large and compact cluster crimped around th edges; crisp and tenest lettuces to grow under glass. cts.; oz. 15 cts.; $1 / 4$ postpaid. B
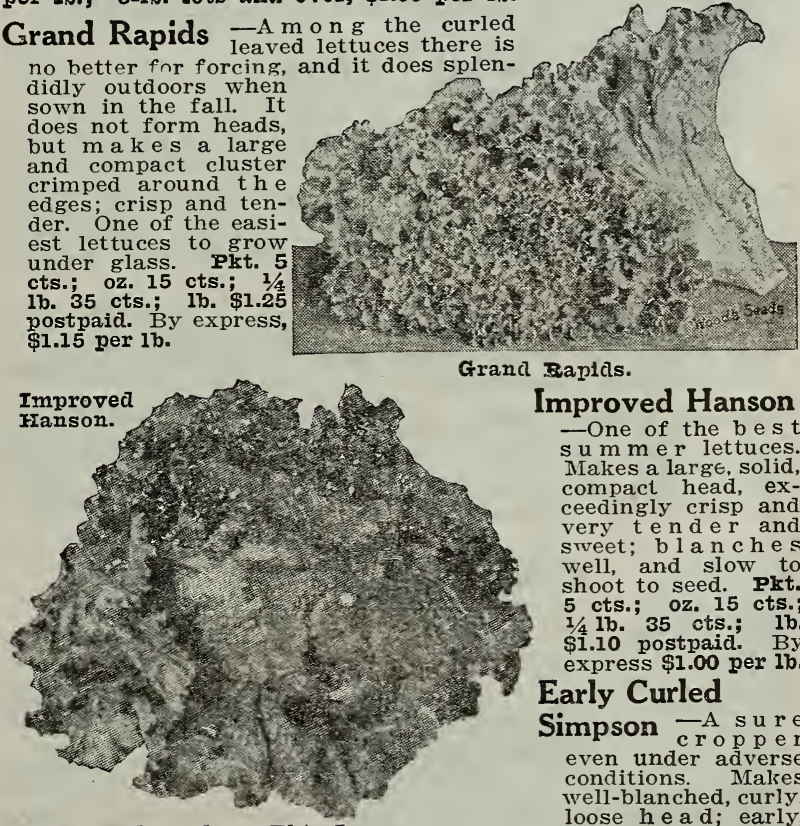

Improved Hanson -One of the best Makes a large, solid, compact head, exe $r$ and srveet: blanches well, and slow to 5 cts.; oz. 15 cts. 1/4 1b. 35 cts.; $1 \mathrm{~b}$
$\$ 1.10$ postpaid. $\mathrm{By}$ express $\$ 1.00$ per 1b.

Early Curled

Simpson cropure even under adverse conditions. Makes loose h e a d; early.

crisp and tender. Pkt. 5 cts.; oz. 15 cts.; 1/41b. 35 cts.; 1b. $\$ 1.10$ postpaid. By express, $\$ 1.00$ per 1b.

Mammoth Black

Seeded Butter ${ }^{-A}$ sure and reliable. Makes large cabbage-like heads, and creamy white inside

tender and of rich, buttery flavor. Pkt. 5 cts.; oz. 15 cts.; 1/41b. 35 cts.; 1b. $\$ 1.10$ postpaid. By express, $\$ 1.00$ per $1 \mathrm{~b}$.

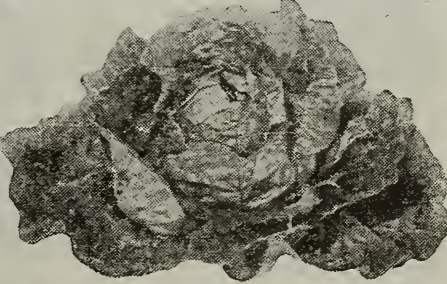

Mixed Lettuce -All varieties on this page; fine for the home LETTUCE PLANTS RFADY SFPTIMBER, OCTOBFR an Big Boston, $40 \mathrm{cts}$. per 100, postpaid. By express, $30 \mathrm{cts}$. per 100 ; $\$ 2.50$ per 1,000 . 
Horse Radish Roots 25 cts. per doz.; 50 for 50 cts.; 75 cts. per doz.; 60 cts. per 100; 500 for $\$ 2.50$; $\$ 4.50$ per 1,000 .

KOHL RABI -Combines the flavors of the cabbage and turroots are 2 to 3 inches thick, when they are very tender and delicate Also makes a fine stock food, yielding 300 to 400 delicate. Also makes a finse sow in drills from June to Sepbushels per acre. For late use, sow in drils from June to sep$1 / 4 \mathrm{lb}$. 65 cts.; $1 \mathrm{~b}$. $\$ 2.35$ postpaid. By express, $\$ 2.25$ per $1 \mathrm{~b}$.

LEEK IARGE FIAG.-Sow in September and transplant in 65 cts.; 1b. $\$ 2.35$ postpaid. By express, \$2.25 per $1 \mathrm{~b}$.

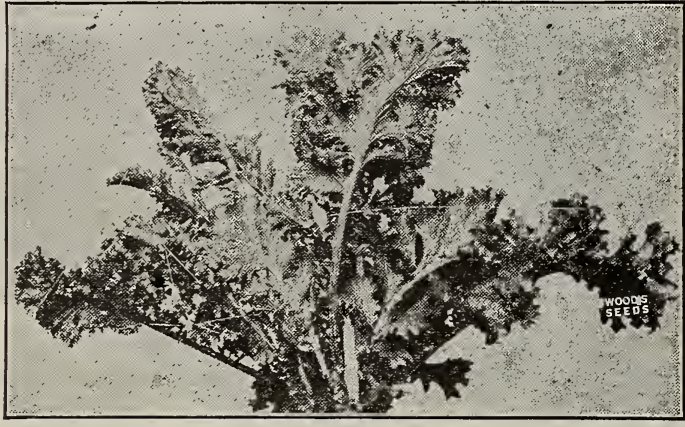

MUSTARD

CUITURF.-Sow during September or October or in February

March or April, either broadcast or in rows six inches apart.

Sow 1 ounce to 80 feet of drill, or broadcast 5 to 6 lbs. per acre.

Chinese Broad Leaved - When prepared like spinach makes from sowing; tender and free from bitter flavor. Pkt. 5 cts.; oz. 8 cts.; $1 / 4$ lb. 25 cts.; 1b. 90 cts. postpaid. By express, 80 cts. per lb.

Ostrich Plume - The most beautiful of all mustards. The fully as an ostrich plume. Stands summer heat splendidly. Pkt. 5 cts.; oz. 10 cts.; $1 / 4 \mathrm{lb} .30 \mathrm{cts}$; 1b. $90 \mathrm{cts}$. postpaid.

Southern Giant Curled - The most popular mustard with mass of leaves beautifully ruffled and finely curled and crimped around the edges: succulent, pungent and of sweet flavor By express, 75 cts. per lb. 4 lb. 25 cts.; 1b. 85 cts. postpaid.

\section{GARDEN PEAS}

All varieties may be planted as late as August in this latitude to make a late crop. The varieties marked $(*)$ are hardy and can be planted as late as September to come in during October or November. Marrowfat Peas planted in November, December and January will make their crop just after the extra early varieties. All varieties, $10 \mathrm{cts}$. per pkt.

-By Mail Post paid- Ly Express or Freight-
Lb. 5 lbs. $10 \mathrm{lbs}$. Lb. 5 lbs. $10 \mathrm{lbs} .100 \mathrm{lbs}$.

\begin{tabular}{|c|c|c|c|c|c|c|}
\hline $\begin{array}{l}\text { *Wood's Pedigree } \\
\text { Extra Early..... } \\
\text { * ood's Lightning }\end{array}$ & 1.30 & 2.25 & .30 & 1.15 & 2.00 & 18.00 \\
\hline Excelsior $\ldots . . .$. & 1.20 & 2.15 & .25 & 1.05 & 1.90 & 17.50 \\
\hline *Extra Early Alaska. & 1.20 & 2.15 & .2 & 1.05 & & \\
\hline${ }^{*}$ Ameer $\ldots . . . \ldots \ldots . . . .$. & 1.20 & 2.15 & .2 & 1.0 & & 17.00 \\
\hline * Large Pod Alaska..... & 1.20 & 2.15 & .2 & 1.05 & 1.90 & 17.00 \\
\hline${ }^{{ }^{*} \text { First and Best........... }}$ & $\begin{array}{l}1.10 \\
1.20\end{array}$ & $\begin{array}{l}2.05 \\
2.15\end{array}$ & .25 & $\begin{array}{r}.95 \\
1.05\end{array}$ & $\begin{array}{l}1.80 \\
1.90\end{array}$ & 16.50 \\
\hline${ }^{*}$ Petit Pois or French.. 35 & 1.40 & 2.45 & .30 & 1.25 & 2.20 & \\
\hline Thomas Laxton........40 & 1.55 & 2.85 & .35 & 1.40 & 2.60 & 24.00 \\
\hline $\begin{array}{l}\text { Eclipse or Surprise.... .35 } \\
\text { American Wonder......35 }\end{array}$ & $\begin{array}{l}1.30 \\
1.30\end{array}$ & $\begin{array}{l}225 \\
225\end{array}$ & .3 & $\begin{array}{l}1.15 \\
1.15\end{array}$ & 2.00 & 18.00 \\
\hline McLean's Little Gem.. . .30 & 1.20 & 2.15 & 2 & 1.0 & 1.9. & 17.00 \\
\hline Nott's Excelsior........40 & 1.5 & 2.6 & .3 & 1.2 & 2.4 & 22.00 \\
\hline $\begin{array}{l}\text { Little Marvel............ } 4 \\
\text { Horsford's Market }\end{array}$ & & & & & 2.4 & 22.00 \\
\hline $\begin{array}{l}\text { Horsford's Market } \\
\text { Garden ................ }\end{array}$ & 1.20 & & & & & \\
\hline McLean's Ädvancer... & & & .25 & 1.05 & 1.90 & 17.00 \\
\hline Bliss Everbearing... & 1.20 & 2.15 & .25 & 1.05 & 1.9 & \\
\hline Dwarf Champion... & 1.55 & 2.85 & .35 & & & \\
\hline $\begin{array}{l}\text { Champion of England. } \\
\text { Telephone } \ldots . . . . . . . . . .\end{array}$ & 1.5 & 2.2 & .3 & $\begin{array}{l}1.0 \\
1.1\end{array}$ & & $\begin{array}{l}17.00 \\
18.00\end{array}$ \\
\hline * White Marrowfat......2 & & & .20 & .85 & 1.55 & 14.00 \\
\hline *Black Eye Marrowfat. .2 & .95 & 1.75 & .20 & .80 & 1.50 & 13.50 \\
\hline
\end{tabular}

\section{PEPPER}

Royal King -An improved Ruby King. Regular in shape, variety and one of the best. Pkt. $10 \mathrm{cts}$; oz. $45 \mathrm{cts}$.; $1 / 4 \mathrm{lb}$. $\$ 1.40 ;$ 1b. $\$ 5.00$ postpaid.

Large Bell or Bull Nose -A large pepper that ripens its fruits, with thick, mild flesh of excellent quality for use in salads or for stuffing. Plkt. 10 cts.; oz. 35 cts.; 1/4lb. $\$ 1.25$;

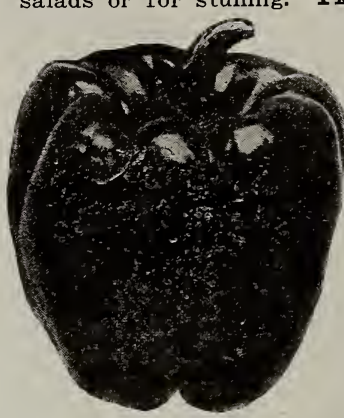

Bell, or Bull Nose. \$4.00 postpaid.

Early Neapolitan - T e n d a y s any large, sweet, mild pepper and a wonderful bearer; single plants often yield 30 to 40 peppers, and continue loaded right up to frost. Bright red, thick meated, v e r y sweet and mild; 4 ins. long by 5 to 6 ins. round; keeps for a long time in nice condition. Pkt. 10 lb. $\$ 5.00$ postpaid.

Pimento - Can be eaten raw like ch it $\mathrm{h}$ meats, rice, etc., and baked; can be served as a salad, made into Spanish omelets, and for canning is especially fontinues in bearing till frost. Pkt. 10 cts.; oz. 35 cts.; $1 / 41$ b. $\$ 1.00$; $1 \mathrm{~b} . \$ 3.50$ postpaid.

Giant Sweet Bull Nose -An extra large and particularly The earliest of the large, sweet peppers, uniform in size and shape, and has exceptionally thick flesh. Pkt. 10 cts.; oz. 50 cts.; $1 / 41 \mathrm{lb} . \$ 1.65$; 1b. $\$ 6.25$.

Ruby King - One of the most varieties. The peppers are a beautifui bright ruby red color, 4 to 6 inches long by 3 to 4 inches across. Flesh very thick, sweet and mild. Pkt. 10 cts.; oz, 40 cts.; $1 / 41 \mathrm{lb}$. $\$ 1.30$; 1b. $\$ 4.75$ postpaid.

Chinese Giant - An enormous ing 12 to 15 inches in circumference and 4 to 5 inches long. Notwithstanding its large size, it is very early and bears an enormous load of fruit; frequently half a dozen will appear in a bunch. The flesh is thick, tender, mild and sweet; may be sliced and eaten like tomatoes, or stuffed as mangoes. Pkt. 10 cts.; Oz. 50 cts.

Crimson Giant - Very early but unusually uniform in size and shape; sweet and mild. Pkt. 10 cts.; oz. 50 cts.; $1 / 41 \mathrm{~b}$. $\$ 1.65$;

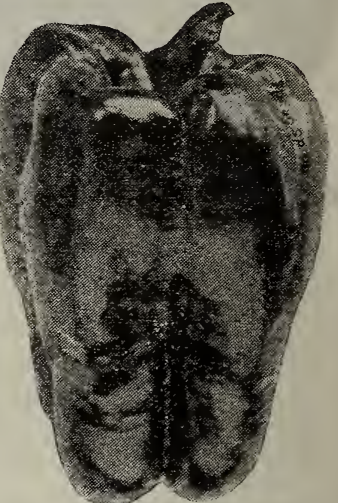

Ruby ring.
Ruby Giant - A beautiful pepper, being a cross between the

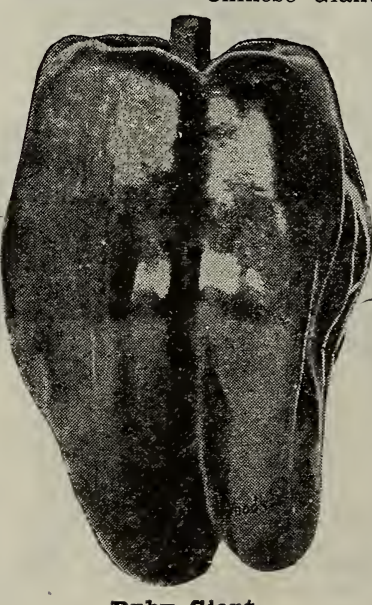
large size and productiveness of the Chinese Giant and the attractive shape and color of the Ruby King; mild and sweet. Pkt. Ib. $\$ 5.00$ postpaiả.

Long Red Cayenne - A strong having long, slender bright red pods about 4 ins. long. Pkt. 5 cts. oz. 25 cts.; $1 / 41 \mathrm{lb}$. 90 cts.; 1b. $\$ 3.25$ postpaid.

Spanish Mammoth or SWrET -A late variety, bearing large thick fruits often 4 to 6 inches long and 2 to 3 inches across mild and sweet; fine for mangoes. $\$ 1.40$; 1b. $\$ 5.00$ postpaid.

Red Clusterer (CHrrr).- Splendie ing pepper sauce and pepper vinegar. Pkt. 10 cts.; oz. 50 cts. $1 / 41 \mathrm{~b}$. $\$ 1.60$.

Tabasco -The hottest pepper

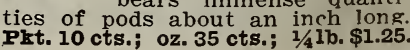




\section{ONION SEEDS FOR FALL PLANTING}

TO GROW IARGF ONIONS FROM SEFD. - Sow in a wellprepared seed bed in August or September, and when the plants are the size of a goose quill transplant 4 inches apart in 12-inch rows, trimming the tops and roots. Don't fail to transplant; it is not unusual to double the yield by transplanting, large onions weighing two pounds and over being grown by this method. For fall sowing we recommend Prize Taker, Mammoth Silver King, ticular are benefited by the transplanting method of culture. One ounce sows 100 feet of drill; 5 to 6 lbs. will transplant an acre.

\section{Spanish or Italian Onions}

\section{Copper King -Attains an enormous}

ing been grown weighing four pounds.

The skin is a reddish color, flesh white

very $s$ w e e t, mild and tender. Enormous crops may be grown by following $t h \mathrm{e}$ transplanting method described above Pkt. 5 cts.; oz. 30 cts. $1 / 4$ ib. \$1.00; ib. $\$ 3.60$ postpaid. By express, $\$ 3.50$ per $1 \mathrm{~b}$.

Extra Early White

Pearl -The quickest of large, pearly-white large, p e a r $1 \mathrm{y}-\mathrm{wh}$ it onions, tender, mild and in the fall to make large white onions early in the spring. Early next sprin plant thickly to $m$ a $\mathrm{k}$ sets for putting out in the fall. Pkt. 5 cts.; oz. 25 cts.; $1 / 41$ b. 90 cts.; 1b. $\$ 3.35$ postpaid. By express, $1 \mathrm{~b}$. $\$ 3.25$.
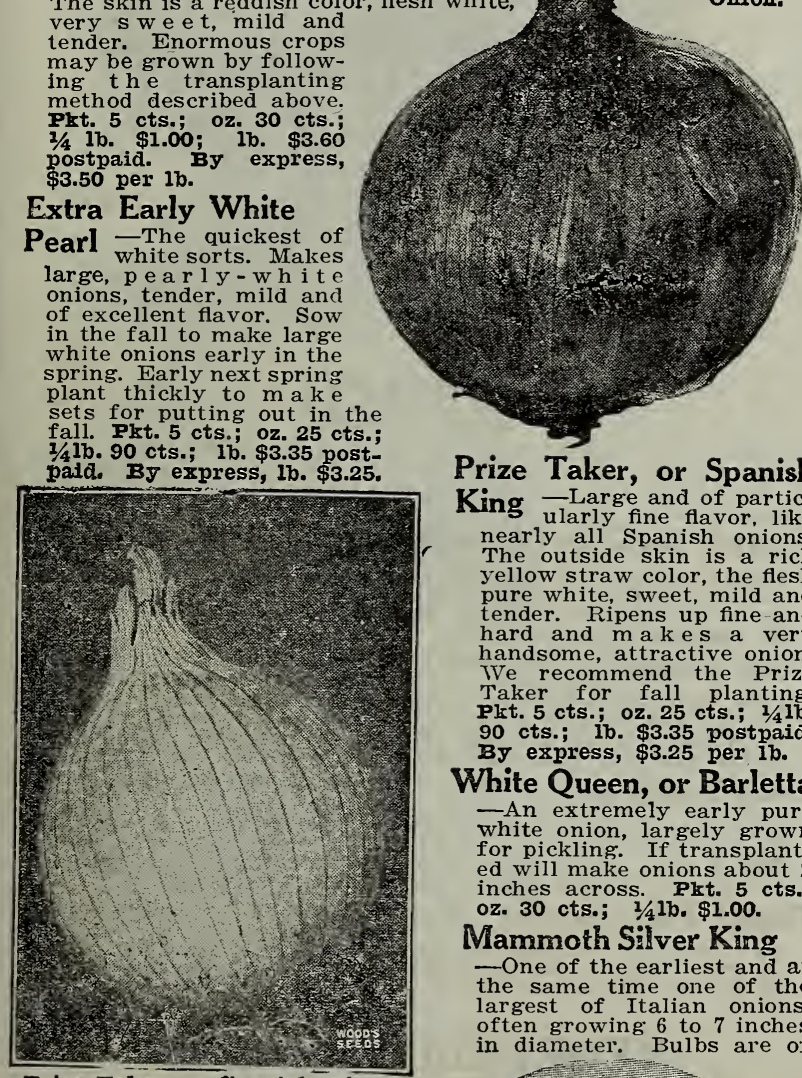

Prize Taker, or Spanish King - Large and of particnearly all Spanish onions. The outside skin is a rich yellow straw color, the flesh pure white sweet, mild and tender. Ripens up fine and hard and $\mathrm{mak}$ a $\mathrm{s}$ a very hard and makes a very Ve recommend the Prize Taker for fall planting. Plat. 5 cts.; oz. 25 cts.; $1 / 41 \mathrm{lb}$. 90 cts.; Ib. $\$ 3.35$ postpaid. By express, \$3.25 per 1b.

White Queen, or Barletta -An extremely early pure white onion, largely grown for pickling. If transplanted will make onions about 2 inches across. Pkt. 5 ct

Mammoth Silver King

-One of the earliest and at the same time one of the largest of Italian onions, largest of Italian onions, in diameter. Bulbs are of

Prize Taker, or Spanish King.

an attractive shape, flattened but thick. Skin is a clear silvery white; flesh pure silvery white; flesh pure white, mild, sweet, and tendhis onion does well in every part of the country, adapting itself to a great variety of soils and climate pkt. 5 cts.; oz. 35 cts.; 1/4ib. $\$ 1.15$; 1b. $\$ 4.10$ postpail. $\mathbf{B J}$ express, $\$ 4.00$ per $1 \mathrm{~b}$.

To make a good garden you must have g o od tools. See what we offer on page 30 .

Eow do you get along without a PIAAN3L JR.?

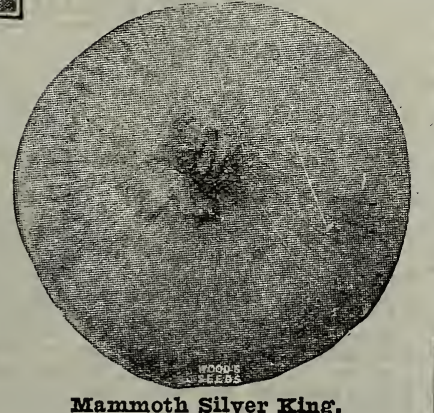

\section{American Onions}

Large Red Wethersfield - The most generally grown red but thick; flesh purplish white, large, somewhat flattened oz. 20 cts.; 1/4lb. 60 cts.; 1b. $\$ 2.10$ postpaid. By express, per 1b. $\$ 2.00$.

Southport Globe Onions - No onion makes as beautiful heavy yielders and good keepers.

SOUTHPORT RED GIOBE.-Color is a deep rich red. Pkt. 5 cts.; oz. 20 cts.; $1 / 41$ b. 60 cts.; Ib. \$2.10 postpaid. By express, $\$ 2.00$ per $1 \mathrm{~b}$.

SOUTHPORT YIIIOW GLOBE. - Rich yellow, hardy and of good size. Plit. 5 cts.; 1b. \$2.35 postpaid. BY express, $\$ 2.25$ per $1 \mathrm{~b}$.

SOUTHPORT WHITE GIOBF. -Skin and flesh silvery white. Pkt. 5 cts.; oz. 25 cts.; $1 / 41 \mathrm{lb}$. 85 cts.; 1b. $\$ 3.10$ postpaid. By express, $\$ 3.00$ per $1 \mathrm{~b}$.

\section{Yellow Globe Danvers}

- Bulbs are medium to large: flesh creamy white, mild and crisp. Pkt. 5 cts.; oz. 25 cts.; $1 / 4$ lb. 75 cts.; lb. $\$ 2.60$ post paid. By express, $\$ 2.50 \mathrm{lb}$.

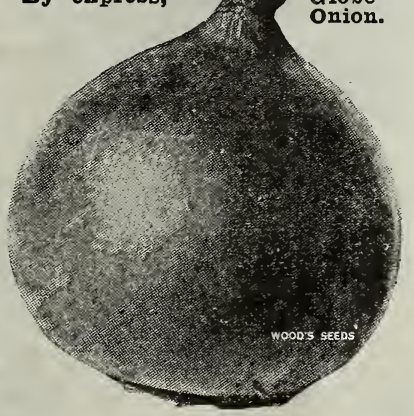

Silver Skin -Flesh and skin pure white; very mild and sweet; 5 cts.; oz. 30 cts.; $1 / 4 \mathrm{lb}$. $\$ 1.00 ;$ 1b. $\$ 3.60$ postpaid. By express, $1 \mathrm{~b}$. $\$ 3.50$.

\section{Onion Sets for Fall Planting}

See Wood's Crop Special for Prices by the Peck and Bushel. CUITURF.-All varieties may be set out in the fall. Plant 4 inches a part in rows 1 foot apart and about half an inch deep, but do not cover the sets entirely, except Potato Onions, which should be planted 9 inches apart in rows 15 inches apart and covered to the depth of an inch. Fall planting should be more generally practiced, as it has proved quite uniformly successful.

FXTRA FARIT WHITE PEARL.-One of the best and most profitable varieties for fall planting. Extra early, pure white, mild and delicate flavor. They grow large and come in earlier than any other variety. Very popular in the trucking sections for early shipping. Qt. 35 cts. postpaid. By express, qt. $25 \mathrm{cts}$.

SIIVER SRIN. - ot 35 cts. postpaicl. By express, qt. 25 cts.

YHITOW DANVERS. -Qt. 30 cts. post. paid. By express, qt. $20 \mathrm{cts}$

YRITOW POTATO (Yellow Multiplier, or Hill onion)Makes a large onion of mild flavor and

of a reddish yellow color and a good keeper. Never makes seed, but divides from the root, one medium-sized onion often producing many medium to small sets. The smallest sets produce one or two large onions, the larger sets from two to twenty onions in a hill. A desirable variety both for market and for home use, and very popular throughout the South: Small sets (about the size of a hulled walnut), qt. 35 cts. postpaid. By express, qt. 25 cts.

WHITE MUITIPIIER.-Differs from the Yellow Potato Onion in color, being pure white and not as large, but is very productive, of finest flavor and a better keeper. Qt. 35 cts. postpaid. By express, qt. 25 cts.

BERMUDA ONION SETS - Grown from imported TeneWHITE BERMUDA.C. 35 cts. postpai ${ }^{2}$ By express, qt. 25c. 


\section{RADISH}

Winter Radiches -Slower in growth than other radishes, but ers. The quality is not so dependent on quick growth as with ers. The quats tis $y$ should have a good, light mellow soil other sorts, but the y should have a good, light, mellow sorly for best results. sow during August, september or early thin out. Then freezing weather comes on take them up and pack in sand in a cool cellar or bury them outside, and they will keep all winter. One ounce sows 50 feet of drill; 8 to 10 pounds sows an acre.

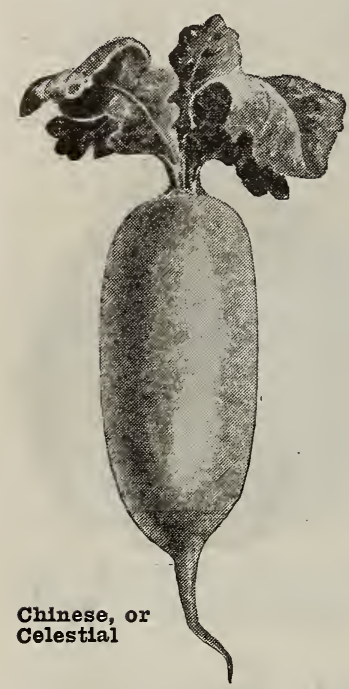

Chinese, or Celestial $\rightarrow \mathrm{A} 1 \mathrm{w}$ a y $\mathrm{s}$ and juicy, and undoubtedly the finest of all extra large, pure white radishes. Grows from 12 to 15 inches long and fully 5 inches thick. Pkt. 5 cts.; oz. 15 cts.; 1/41b. 45 cts.; 1b. \$1.60 postpaid. By express, $\$ 1.50$ per $1 \mathrm{~b}$.

Rose China Winter in Cylindrical medium size; bright deep rosecolored skin. The flesh is white, very solid and of the very finest quality. The most popular of all the winter radishes; a fine keeper. Plkt. 5 cts.; oz. 15 cts.; 1/41b. 45 cts.; 1b. $\$ 1.60$ postpaid. By express, $\$ 1.50$ per 1b.

Long Black Spanish -One of the hardiest varieties. Has dark brown skin; oblong in shape, holding its thickness throughout. Pkt. 5 cts.; postpaid. By express, $\$ 1.50$ per $1 b$.

Long White Spanish Differs from Spanish only in color of skin. Flesh white, firm and pungent; 6 to 8 inches long. Keens like a turnip. cts.; lb. $\$ 1.60$ postpaid. $1 / 4$ By express, $\$ 1.50$ per lib.

\section{Other Well-Known Radishes}

FOR FULI DESCRIPTION, SEE OUR SPRING CATALOG

All of the following varieties should be sown in cold-frames to afford protection during severe winter weather; or they may be sown in hot-beds at intervals during the winter. By growing in hot-beds fresh radishes may be had throughout the winter. One ounce sows 50 feet of drill.

By Ex-

Pkt.
.05
.05
.05
.05
.05
.05
.05
.05
.05
.05
.05
.05
.05
.05

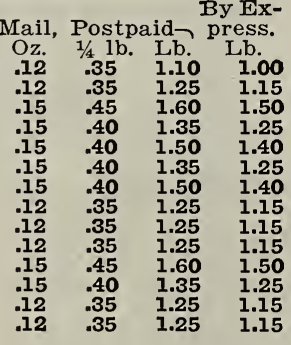

TOMATO

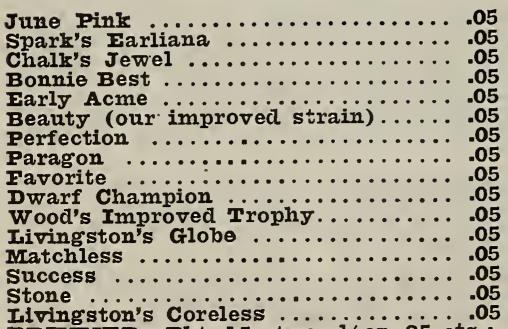

$.25 \quad .90 \quad 3.10$

.903 .10

$.25 \quad .90 \quad 3.10$

$.25 \quad .90 \quad 3.10$

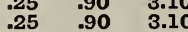

$\begin{array}{lll}.25 & .85 & 2.85\end{array}$

$\begin{array}{lll}.25 & .85 & 2.85 \\ .25 & .85 & 2.85\end{array}$

$\begin{array}{lll}.25 & .85 & 2.85 \\ & .90 & 3.10\end{array}$

$\begin{array}{lll}.25 & .90 & 3.10 \\ .25 & .85 & 2.85\end{array}$

$\begin{array}{rrr}.25 & .85 & 2.85 \\ .30 & 1.00 & 3.60\end{array}$

$\begin{array}{rrr}.30 & 1.00 & 3.60 \\ .25 & .85 & 2.85\end{array}$

$\begin{array}{lll}.25 & .90 & 3.10\end{array}$

$.20 \quad .75 \quad 2.60$

2.50

Iivingston's Coreless .................

BRIMIIrR-Pkt. $15 \mathrm{cts.;} i / 40 z$. 35 cts.;

\section{Rhubarb Roots}

-In November set out 4 feet apart in rich soil in a shaded place, using ground loose and mulch with straw or leaves so as o retain the moisture. Protect with manure during winter. By mail, postpaid, 15 cts. each; $\$ 1.25$ per doz. By express, 10 cts. each; $\$ 1.00$ per doz.; 50 for $\$ 3.50 ; \$ 6.50$ per 100 .

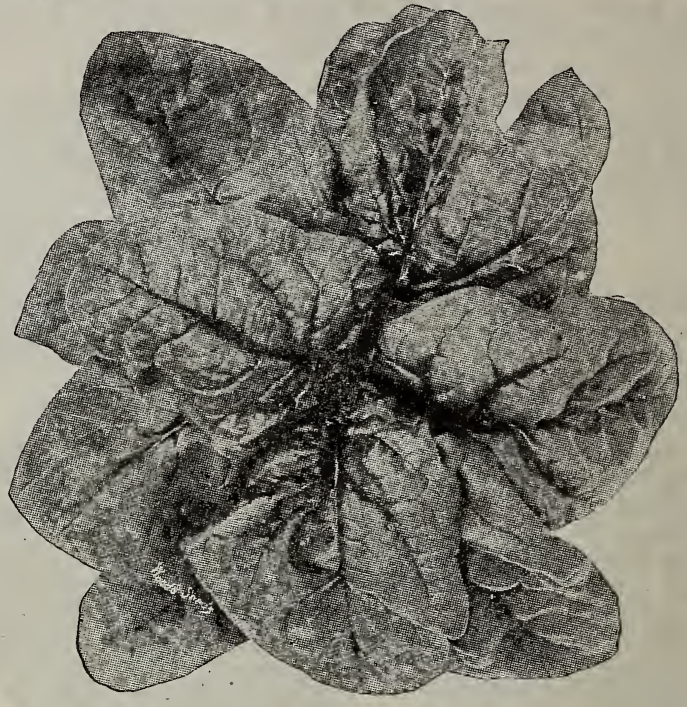

\section{SPINACH}

For fall use sow in August or September; for winter or spring sow from the end of September till December-one inch deep, in drills 12 to 15 inches apart. Requires little cultivation. One ounce will sow 100 feet of drill; 12 to $15 \mathrm{lbs}$, one acre.

Norfolk Savoy or Bloomsdale - The earliest variety and Grows upright with thick dark green leaves, curled like a Savoy cabbage. Very hardy and grows rapidly. Pkt. 5 cts.; oz. 8 cts.; $1 / 4$ lb. 20 cts.; lb. 60 cts. postpaid. By express, 50 cts. per 1b.; 10-1b. lots, 45 cts. per 1b.

Long Season -A splendid spinach, forming a rosette of inpled leaves, which remain fresh long after cutting. No other variety will stand so long without running to seed. Plt. 5 cts.; oz. 8 cts.; $1 / 4$ lb. 20 cts.; lb. 70 cts. postpaid. By express, 60 cts. per 1b.; 10-1b. lots, 55 cts. per $1 \mathrm{~b}$.

Long Standing -An improved strain of excellent quality for maturity it remains in condition longer than most kinds. Leaves comparatively smooth and very dark rich green. Plkt. 5 cts.; oz. 8 cts.; $1 / 4$ lb. 20 cts.; 1 b. 65 cts. postpaid. By express, 55 cts. per 1b.; 10-1b. lots, 50 cts. per $1 \mathrm{~b}$.

Round Thick Leaved -Grows very rapidly, making a cluskled leaves of the finest quality. Pkt. 5 cts.; oz. 8 cts.; $1 / 4 \mathrm{lb}$. 20 cts.; 1b. 65 cts. postpaid̃. By express, 55 cts. per lb.; 10-lb. lots, 50 cts. per $1 \mathrm{~b}$.

\section{VEGETABLE PLANTS}

We supply all kinds of vegetable plants in their proper seasons. Late cabbage, cauliflower and celery up to September 15th; lettuce, early cauliflower and early cabbage during October and November. Whenever we cannot supply the varieties ordered, we will send a variety as closely resembling it as possible.

IATE CABBAGE.-By mail 50 cts. per 100 postpaid. By express, 40 cts. per $100 ; \$ 3.50$ per 1,000 .

FARIY CABBAGE. - BY mail $50 \mathrm{cts}$. per 100 postpaid. By express, 40 cts. per 100; $\$ 3.50$ per 1,000 .

IETTUCE.-By mail $40 \mathrm{cts}$. per 100 postpaid. By express, $30 \mathrm{cts}$. per 100; $\$ 2.50$ per 1,000 .

CAUIIFIOWER. By mail $\$ 1.10$ per 100 postpaid. By express, \$1.00 per 100; $\$ 8.00$ per 1,000.

SAGE.-BY mail postpaid, 20 cts. each; $\$ 1.25$ per doz. By exSAGE.-By mall postpaid, 20 cts. each; $\$ 1.25$ per doz. By ex-
press, I5 ct. mall $\$ 1.00$ per doz.
THYME. - By mall postpaid, 20 cts. each; $\$ 1.25$ per doz. By ex-

press, 15 cts. each; $\$ 1.00$ per doz.

ASPARAGUS ROOTS-See page 17.

REUBARB ROOTS.-See top of this page. 
CUT - Sow the early sorts in July or August, the later sorts during August and the salad varieties during August and September. Sow either broadcast or in drills 2 feet apart, thinning out to 6 inches, and roll the ground after sowing. Sow Rutabagas in July and early August, and earth up as they grow. with sand to keep them fresh, or they may be put into pits or kilns outside. Select a well-drained situation on which to pile the turnips, cover with a few inches of straw and then sufficient earth to keep out frost. Thus protected, they will keep into the winter.

One ounce sows 100 feet of drill; $11 / 2$ pounds sows one acre in drills; 2 pounds one acre broadcast; sow salad varieties 3 pounds to an acre.

Milan Turnips -The Milans leave nothing to be desired in are the earliest varieties an extra early garden turnip. They any other: have small tops, so that the rows can be planted ciose together. The flesh is clear ivory white; the skin is perfectly smooth. They are without an equal for the table, being of the most delicate flavor. Medium size, flat shape.

FXTRA FARIY PURPIE TOP MIIIAN.-The roots are clean, smooth, flat and handsome. The flesh is pure white, tender and sweet. Pkt. 5 cts.; oz. 20 cts.; 1/41b. 60 cts.; lb. $\$ 2.10$ postpaid By express, $\$ 2.00$ per $1 \mathrm{~b}$

FXTRA FARIY WHITE MIIAN.-Similar to the above, except that it is white all over. Pkt. 5 cts.; oz. 20 cts.; 1/41b. 65 cts. 1b. $\$ 2.35$ postpaid. By express, $\$ 2.25$ per 1b.

Wood's Improved Red Top White Globe-An improved

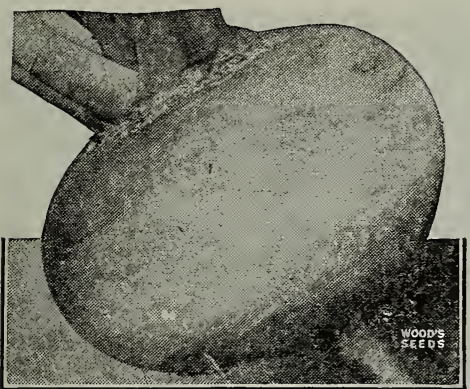

Wood's Improved Red Top Globe. from roots selected for size, shape, quality and small tops. Very popular for market and hom e us e, also for stock. Pkt. 5 cts.; oz 12 cts.; $1 / 1$ lb. 30 cts.; express, $\$ 1.00$ per $1 \mathrm{~b}$.

MATMMOTH RED TOP W HIT GIOB $\mathbf{T}$. Makes large globeshaped roots, white with purple tops. A big yielder; fine for the table, market and stock feeding. Pkt. 5 cts. oz. $10 \mathrm{cts}$.; $1 / 4 \mathrm{lb} .25 \mathrm{cts}$.; express, $70 \mathrm{cts}$. per $1 \mathrm{~b}$. EARIY RED, or PUR PIE TOP (Flat Strapleaved). - Flat; white with purple top; fine-grained and tender. The most popular of all varieties, and the best seller. Pkt. 5 cts.; oz. 10 cts. $1 / 1$ 1b. $25 \mathrm{cts}$.; lb. 75 cts. postpaid. By express, 65 cts. per $1 \mathrm{~b}$.

FARIY WHITE FIAT DUTCH.-Exactly like the Early-Red or Purple-Top, except that it is pure white. One of the best for the family garden; sweet and tender. Pkt. 5 cts.; oz. 10 cts.; $1 / 4 \mathrm{lb}$. $25 \mathrm{cts}$.; 1b. 75 cts. postpaid. By express, 65 cts. per $1 \mathrm{~b}$. IONG WHITE COWHORN.-A very productive quick-growing turnip of excellent quality, fine-grained and very sweet. Often used as a soil improver. Pkt. 5 cts.; oz. 12 cts.; 1/41b. 30 cts.; lb. $\$ 1.10$ postpaid. By express, $\$ 1.00$ per $1 \mathrm{~b}$.

with variety with small tops. Flesh sweet, firm and mild, Pkt. 5 cts. oz. 10 cts.; 1/41b. 25 cts.; 1b. 75 cts. postpaid. By express; 65 cts. per 110.

POMERANIAN WHITE GIOBE. - Extra large, round, white: fine for table and stock; a big yielder. Pkt. 5 cts.; oz. $10 \mathrm{cts}$;
$1 / 4 \mathrm{lb}$. $25 \mathrm{cts}$.; lb. 75 cts. postpaid. By express, 65 cts. per lb.

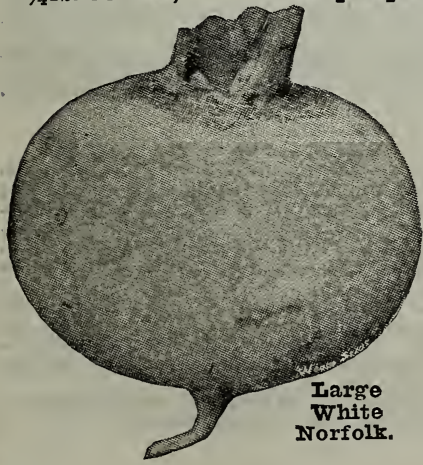
ARGE WHITE NORFOIR GIOBE.-Makes large, round white roots, excellent for table or stock: also quite la $r$ ge $1 \mathrm{y}$ used for winter salad. Pkt. 5 cts.; oz. 10 cts.; 1/41b. 25 cts.; 1b. 75 cts. postpaid. By express, 65 cts. per $1 \mathrm{~b}$

IARGE WHITE GIOBE. One of the biggest vielders: solid and firm. Pkt. 5 cts.; oz. 10 cts.; 1/4 1b. 25 cts.; 1b. 75 cts. postpaid. By express. 65 cts. per $1 \mathrm{~b}$.

SOUTHir SNOW WHTT GIOB $\mathbf{I}$. - Very superior large white, round turnip. Flesh firm and solid. Pkt. 5

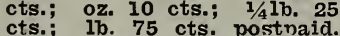
By express, 65 cts. per $1 \mathrm{~b}$.
WHIT SWEFT GFRMAN - Fine for table and $s^{\prime}$ uck: flesh hard, firm and sweet; a good keeper. Pkt. 5 cts.; oz. 10 ctw.; $1 / 4 \mathrm{lb}$. $25 \mathrm{cts}$; $1 \mathrm{~b}$. 80 cts. postpaid. By express, 70 cts. per lb. IARGE ANBBER, or YII- Amber, or IOW GIOBE. - Of large Amber, or size, globe-shaped, solid yellow flesh. Fine for keeper. Pkt. 5 cts.; oz. 10 cts.; $1 / 41 \mathrm{lb} 25$ cts.; express, 65 cts. per $1 \mathrm{~b}$. PURPIF TOP YIIIOW ABERDENA.-A splendid keeper. Flesh is yellow very solia, tender and yielder; tne stock turcts.; 1/41b. 25 cts.; 1b. 75 cts. postpaid. By express, 65 cts. per $1 \mathrm{~b}$. G OIDE N B A I I, or
ORATGE JEIIY.-One of

of most excellent flavor. Pkt. 5 cts.; oz. 10 cts.; $1 / 41 \mathrm{~b} .25$ cts. 1b. 85 cts. postpaid. By express, $75 \mathrm{cts}$. per $1 \mathrm{~b}$.

Mixed Turnip Seeds - A fine home garden mixture of all varie1/4lb. 25 cts.; 1b. 75 cts. postpaid. By express, 65 cts. per lb.

\section{SALAD VARIETIES}

SOUTHFRN PRIZE or DIXIF.-Hardy and needs no protection the most popular turnip grown for winter and spring salad. Pkt. 5 cts.; $0 z .10$ cts.;
By express; 65 cts. per lb.

SEVEN TOP.-A very hardy variety, grown exclusively for salad. Pkt. 5 cts.; oz. 8 cts.; 1/4lb. 20 cts.; lb. 60 cts. postpaid. By express, 50 cts. per Ib.

\section{RUTA BAGA or SWEDE}

CUITURE-Sow in July, or early in August, in drills; thin ou and keep clear of weeds. See under head of turnip culture for directions for storing for winter.

Wood's Improved Purple Top Yellow - A n improved

finest yellow-fleshed rutabaga grown from roots selected for large size, uniformity in shape and fine quality. Hardy, sweet, a good keeper and
the best shaped and $m$ os t productive. Pkt. 5 cts.; oz. 12 cts.; 1/41b. 30 cts.; lb. 90 cts. postpaid. By express, $80 \mathrm{cts}$. per $1 \mathrm{~b}$.

\section{PURPTE-TOP}

YEIIOW.-The old standard variety largely grown for table and stock. A large yielder; good ke per; hardy, Sweet and solid. cts. : 1/41b. 25 cts.

1b. 85 cts. postpaid. By express, 75 cts. per $1 \mathrm{~b}$.

IARGE WHITE, or RUSSIAN.-The flesh is white, firm, sweet; grows large; fine for table and stock. Pkt. 5 cts.; oz. 10 cts. $1 / 4 \mathrm{lb}$. $25 \mathrm{cts}$; 1b. $85 \mathrm{cts}$. postpaid. By express, $75 \mathrm{cts}$. per lb.

BREADSTONE, or BUDIONG. - Makes handsome medium-sized roots of superior table quality. Pkt. 5 cts.; oz. $12 \mathrm{cts}$; $1 / 41 \mathrm{~b}$. $30 \mathrm{cts}$; 1b. $90 \mathrm{cts}$. postpaid. By express, $80 \mathrm{cts}$. per 1b.

\section{PLANET JR. No. 16}

A Planet Jr. will take the drudgery and hardest work out of gardening, and make it a real pleasure. Look on pelect the one that suits you best, and you will thank us for telling you about them. 


\section{FLOWER SEEDS FOR FALL SOWING}

In the South perennials, biennials and hardy annuals may be sown outside in the fall. These sowings make finer plants, much earlier and larger blooms and more brilliant colors. Perennials and biennials bloom the next summer, advancing the blooming season a year. Annuals should have a slight covering of straw in extreme weather; tender perennials should be carried through the winter in the house.

\section{For Full Descriptions See Annual Catalog}

\section{HARDY PERENNIALS and BIENNIALS}

A.TTIRRHINUM or Snapdragon.-Plst. 5c; $1 / 4$ oz. $20 \mathrm{c}$; oz. $65 \mathrm{c}$.

QUII.EGIA, or COIUMIBINE.-Double and Single IMixed, plkt. 5c; $1 / 4$ oz. $20 \mathrm{c}$; oz. $50 \mathrm{c}$. CAIIIOPSIS.-Ianceolata, pkt. $5 \mathrm{c} ; 1 / 4 \mathrm{oz}$. 15c.

CANTFRBURY BEIIS. - Single, pkt. 5c; $1 / 4$ oz. 15c Double, pkt. 5c; $1 / 4$ oz, 25c. Calycanthema, pkt. $5 \mathrm{c} ; 1 / 8$ oz. $20 \mathrm{c}$.

CARNATION. - Irixed, pkt. 5c; 1/4 oz. 45c; oz. \$1.50. Finest German Double Irixed, pkt. 15c. Marguerite, pkt. 8c; $1 / 4$ oz. 40c. Cinavaud's Perpetual, pkt. 10c; $1 / 4$ oz. COc. CENTAUREA.-Margarita, pkt. 5c; $1 / 4 \mathrm{oz}$. 25c. Gymnocarpa, pkt. 5c; $1 / 2$ oz. $30 \mathrm{c}$; oz. $50 \mathrm{c}$

CHRYSANTHFMUM.Japanese, pkt. 15c. DAISY-Shasta, pkt. 10c; $1 / 8$ oz. $35 \mathrm{c}$

DAISY, DOUBIE. Pure White, pkt. 5c. Mrixed colors, pkt. 5c.

DIANTHUS or PINK.-Wood's Superb Mixture, pkt. 10c; $1 / 4$ oz. $20 \mathrm{c}$; oz. 60c. Wood's Irixture of Double Pinks, pkt. 5c; $1 / 4 \mathrm{oz}$. $15 \mathrm{c} ;$. Oz. 50c. Wood's IMixture of Single Pinks, pkt. 5c; 1/4 oz. $15 \mathrm{c}$; oz. 40c. Double fril, pkt. 8c; $1 / 4$ oz. 40c. Double China and Double Japan, pkt. 5c; $1 / 2$ oz. $20 \mathrm{c}$.

TENDER PERENNIALS ABUTILON.-Mixed colors, pkt. 10c.

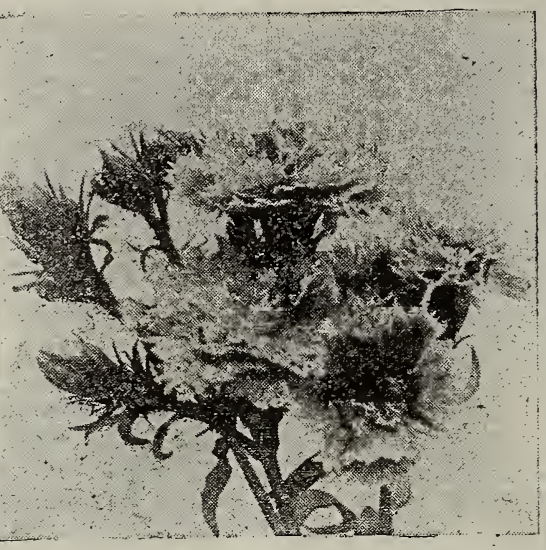

Wood's Superb Dianthus.

DIGITAIIS.—Pkt. 5c; $1 / 4$ oz. 20c.

ISCHOITZIA.-Bush, pkt. $5 \mathrm{c} ; 1 / 4$ oz. $20 \mathrm{c}$. FORGFT-IMF-NOT.-Mixed, pkt. 5c; $1 / 4$ oz. $25 c$

GAITIARDIA.-Grandifiora, pkt. 5c; $1 / 4 \mathrm{oz}$.

GYPSOPHIIA.-Pkt. $5 \mathrm{c} ; 1 / 4$ oz. $25 \mathrm{c}$.

EOILYHOCK. - Double II i x e d, pitt. $5 \mathrm{c}$; $1 / 4$ oz. 25c. Allegheny, pkt. $8 \mathrm{c} ; 1 / 4$ oz. $30 \mathrm{c}$ Double Fverblooming, pkt. $10 \mathrm{c} ; 1 / 4$ oz. 35c. Single Iverblooming, pkt. 5c; $1 / 4$ oz. $20 \mathrm{c}$ TENIT,WORTH IVY.-Pkt. 5c.

IARKSPUR.-Perennial, pkt. 5c; $1 / 2$ oz. $40 \mathrm{c}$; 0z. 75c.

IYCHNIS-Pkt. 5c; $1 / 2$ Oz. 25c. Flowering Plst. $10 \mathrm{c} ; 1 / 4$ oz. $20 \mathrm{c}$.

POPPY -Iceland, pkt. 5c; $1 / 4$ oz. 25c; oz 75c. Oriental, plet. 10c; $1 / 4$ oz. 3Cc.

PYRETHRUM.-Fkt. $5 \mathrm{c} ; 1 / 4 \mathrm{oz} .15 \mathrm{c}$.

ROSE CANIPION_-Pkt. 5c; $1 / 4$ oz. 15c. STOKFSIA CYANTEA.-Plrt. 10c.

SUNFIOWER.-Perennial, pFt. 10c; $1 / 4$ oz. $60 \mathrm{c}$.

SWFFT WIIIIAMr-Single Mixed, pkt. 5c; $5 c ; 1 / 4$ oz. $25 \mathrm{c}$; oz. $75 \mathrm{c}$.

CYCLAIIEN PERSICUM.-PKt. 15c.

VINCA. Rosea anc Alba, each, pkt. $5 \mathrm{c} ; 1 / 4 \mathrm{oz}$ 35c. Irixed Colors, pkt. 5c; $1 / 4 \mathrm{oz}$. 30c.
WAIIFIOWER. - Single Mixed, pkt. 5c; $1 / 4$ oz. 15c. Double Mixed, pkt. 10c; $1 / 8$ oz. 50. $\mathrm{Oz}$.

\section{HARDY ANNUALS}

ASTFR-Ostrich Plume, pkt. 10c; 1/4 oz. 40c. Giant Comet.-Pkt. 10c; $1 / 4$ oz. $40 \mathrm{c}$

Wood's Superb Mixture-Pkt. 10c; 1/ oz. $50 \mathrm{c}$; $1 / 4$ oz. $85 \mathrm{c}$; oz. $\$ 3.00$.

German Quilled, or China.-Mrixed Colors, pkt. $5 \mathrm{c} ; 1 / 2$ oz. $35 \mathrm{c}$; Oz. $60 \mathrm{c}$.

Peony rlowered Perfection. $-\mathbf{P}$ u $\mathbf{r} \theta$ White and Pink, each, pkt. 10c; $1 / 4$ oz. 40c. IMixed colors, pkt. $8 \mathrm{c}$; $1 / 4$ oz. $35 \mathrm{c}$.

Semple's Branching.-Pure white, Pink, Blue and Dark Scarlet, each, pkt. 10c; $1 / 4$ oz. 35c. Mixed colors, pltt. 8c $1 / 4$ oz. 35c.

Comet.-Pure White, Iight Blue, Crimson, and Pink, each, pkt. 10c; $1 / 4 \mathrm{oz}$ 35c. Mixed colors, pkt. 8c; $1 / 4 \mathrm{oz}$. 35c.

Victoria.-Pure White, Pink, Iight Blue and Dark Scarlet, each, pkt. 10c $1 / 4$ oz. $50 \mathrm{c}$

ABRONIA.-For rockeries, pkt. $5 \mathrm{c}$.

ACROCIINIUM.-Pkt. $5 \mathrm{c}$; $1 / 4 \mathrm{oz} .15 \mathrm{c}$

AGERATUM - Mexicanum, pkt. 5c; $1 / 20 \mathrm{o}$ $20 \mathrm{c}$; Oz. 35c.

AIYSSUMI. - Sweet, pkt. 5c; $1 / 2$ oz. $20 \mathrm{c}$ Iittle Gem, pkt. 5c; 1/2 oz. 25c; oz. $40 \mathrm{c}$. Iittle Dorrit, pkt. 7c; $1 / 4$ oz. $20 \mathrm{c}$.

CACAIIA.-Pkt. 5c; $1 / 4$ oz. 20c.

CAIENDUIA.-Mixed colors, pkt. 5c; 1/2 oz. $15 \mathrm{c}$; oz. 25c.

CAIIIOPSIS.-Golden Wave, pkt. 5c; $1 / 4 \mathrm{oz}$.

15c. IMixed colors, pkt. 5c; $1 / 2$ oz. $15 \mathrm{c}$. Tiger Flower and Fire king, each, pkt. 10c. CANDYTUYT.- Fmpress, pkt. 5c; $1 / 2$ oz. 15c. White Rocket, pkt. 5c; oz. 20c. Mixed colors, pkt. 5c; oz. $20 \mathrm{c}$.

CATCHYXYX.-Pkt. 5c; oz. 20c.
CENTAUREA.-Cyanus, pkt. 5c; 1/20z.

CFRYSANTHFMUN. - Fvening Star, pkt.

10c Mroring Star, prt. 10c. IMixed varieties, pkt. 5c; $1 / 2$ oz. 15c. Double Early Flowering, pkt. $15 \mathrm{c}$.

CLARKIA. 'Pkt. 5c; oz. 30c.

COCKSCONms. Tall Mrixed, plst. $5 \mathrm{c} ; 1 / 4 \mathrm{oz}$. 30c. Dwarf Mixed, pltt. 5c; 1/4 oz. 40c. Plumed Varieties, mixed, pkt. $52 ; 1 / 2$ oz. 20c. Variegated Ieaved, pkt. 25c.

DAISY.-African, pkt. 10c.

ESCHOITZIA.Pkt. 5c; oz. 20c.

FEVEREFW.-Pkt. 5c; $1 / \mathrm{p}$ oz. $20 \mathrm{c}$; oz. 35c. GAIIIARDIA.-Mixed colors, pkt. $5 \mathrm{c}$; $1 / 2 \mathrm{oz}$. $15 \mathrm{c} ; 0 z .25 \mathrm{c}$.

GIIIA.-Pkt. 5c; $1 / 2$ oz. $10 \mathrm{c}$

GIOBE AMARANTH. - Pkt. $5 \mathrm{c} ; 1 / 2$ oz. $15 \mathrm{c}$

GODETIA. Pkt. 5c; $1 / 2$ oz. $20 \mathrm{c}$.

HEIICHRYSUI.-Pkt. $5 \mathrm{c}$; $1 / 2$ oz. $20 \mathrm{c}$.

FIBISCUS.-Pkt. 5c; $1 / 2$ oz. $15 \mathrm{c}$.

ICP PIANT.-Pkt. $5 \mathrm{c}$; $1 / 4$ oz. $15 \mathrm{c}$.

JOB'S TEARS. - Pkt. 5c; oz. 10c; $1 / 4$ 1b. $30 \mathrm{c}$ KOCHIA Or BURNING BUSH.-Pkt. $5 \mathrm{c}$. IARKSPUR. Annual, pkt. $5 \mathrm{c} ;$ oz. $30 \mathrm{c}$. IINUIM-Pkt. 5c; $1 / 2$ oz. $15 c$.

MIAIGOID. - African and French, each, pkt. $5 \mathrm{c} ; 0 \mathrm{z} .30 \mathrm{c}$

MARVEI OF PERU.-PKt. 5c; oz. 15c

MIGNONETTE. - Sweet, pkt. 5c; oz. 15c

$1 / 4$ 1b. 35c. Wood's superb Misture, pkt. 10c; $1 / 2$ oz. 30c; oz. 50c. Defiance and Matchet, pkt. $5 \mathrm{c}$; $1 / 2$ oz. $25 \mathrm{c}$.

VASTURTIUM.-Separate colors, pkt. $5 \mathrm{c}$ oz. $15 \mathrm{c} ; 1 / 4 \mathrm{lb}$. 50c. Mrixed colors, pkt. $5 \mathrm{c}$ oz. 15c; $1 / 4$ 1b. 45c. Wood's Peerless Mixtures, pkt. 10c; oz. 20c; $1 / 4 \mathrm{lb}$. $60 \mathrm{c}$.
NEMOPHIIA-Pkt. 5c.

INICOTIANA SANDERAF.-PKt. 5c. NIGEIIA.-Pkt. 5c; $1 / 2$ oz. 15c.

PHLOX.-ITixed colors, pkt. 5c; $1 / 4$ 0z. 25c; oz. $75 \mathrm{c}$.

GRANDIFIORA PHIOX.-Separate Colors, pure white, rose pink, scarlet, yellow, and dark purple, each, pltt. 10c. Grandiflora IMixed Colors, pkt. 8c; 1/4 oz. 30c; oz. \$1. POPPY.-Wood's Superb Mixture, pkt. 10c; $1 / 2$ oz. 25c; oz. 40c. Special Single Mixture and Special Double Mixture, Admiral, Double Scarlet, Tulip, King Fdward and Shirley, each, pkt. 5c; 1/2 oz. 15c; oz. 25c. Featherball, pkt. 5c; $1 / 4$ oz. 15c. Carnation Flowered and Peony rlowered, each, pkt. 5c; oz. $20 \mathrm{c}$.

PRIMROSE-Evening, pkt. 5c; $1 / 2$ oz. $25 \mathrm{c}$. RUDBECKIA.-Pkt. $5 \mathrm{c} ; 1 / 4$ oz. $25 \mathrm{c}$.

SCABIOSA, Or MOURNING BRIDE.-PLt. $5 \mathrm{c} ; 1 / 4 \mathrm{oz} .15 \mathrm{c}$.

SUMIMER IIR.-Pkt. $10 \mathrm{c}$

SWEET SUITAN.-Pkt. 5c; $1 / 4$ oz. $25 \mathrm{c}$.

VERBENA.-MTixed, pkt. $5 \mathrm{c} ; 1 / 4$ oz. $25 \mathrm{c} ; \mathrm{oz}$

75c. INammoth MLixed, pkt. 8c; 1/4 oz. 30c oz. \$1.00. Mammoth white, pkt. 10c; $1 / 4 \mathrm{Oz}$ 35c; Defiance, pkt. 8c; $1 / 4$ oz. 30c; oz. $\$ 1$. VIRGINIAN STOCK.-Pkt. 5c; $1 / 2$ oz. $15 \mathrm{c}$ WAILFIO WrR.-Annual, pkt. $10 \mathrm{c} ; 1 / 4 \mathrm{oz}$. $25 \mathrm{c}$

ZINNIA.-Double Mixed, pkt. 5c; $1 / 2$ oz. 25c; oz. 40c. Grandiflora Mixed, pkt. 10c; $1 / 20 z$. $40 \mathrm{c}$; oz. 75c. Curled and Crested, Minia ture, Tom Thumb and Striped or Zebra, each, plst. $5 \mathrm{c}$; $1 / 4$ oz. $25 \mathrm{c}$.

WIID FIOWER GARDEN MIXTOREPlkt. 5c; oz. $15 \mathrm{c}$; $1 / 4$ lb. $40 \mathrm{c}$. 


\section{WOOD'S ROYAL PANSIES}

PIANT IN THE FAII
FOR TMIE EARIITST AND
TARGEST BIOONS

Saved from plants selected for the beauty and size of their blooms, our aim being variety and brilliancy of colorings, strong marking, abundance of bloom and long keeping qualities. Fall sowings produce earlier, larger and more brilliant blooms than spring sowings. They will stand the severest winter without protection. Grow them in a shady position in a rich, moist soil.

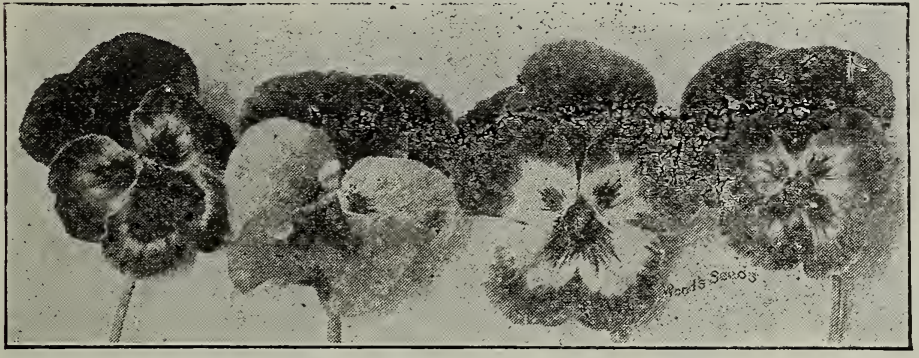

Wood's Royal Pansies.

\section{PANSY MIXTURES}

Wood's Royal Pansy IIixture.-A magnificent mixture, excelling in an endless variety of the richest colors, which. with the large size and perfect form, make it indeed a "royal mixture." Pkt. 10 cts.; 3 pkts. for 25 cts. 1/80z. 60 cts.; 1/40z. $\$ 1.00$.

Wood's Exhibicion Pansy Mixture.-The richest and hand somest pansy mixture in existence. It contains seeds saved from the finest specimen piants grown by eminent pansy specialists, making a mixture as near perfect as inches across, of every imaginable pansy color and combination of colors, some five-spotted, others margined. veined, blotched and mottled in an enfless variety. Pkt. 25 cts.; 3 pkts. for 65 cts.; 1/30z. \$1.C0.

Wood's Superb Frilled.-Each petal is frilled or curled giving the appearance of a double pansy. This unusual formation adds greatly to its keeping quality. Our mixture contains all the newest introductions and is Mixed Pansies.-Large Flowering.-A very superior mixture of all colors, shades and markings; rich and beautiful. Pkt. 5 ctz.; 1/40z. 40 cts.; oz. \$1.25.

Giant Trimardeau. - A distinct strain with remarkably large blooms, generally marked with large blotches: colors rich and varied. Pkt. 8 cts.; 1/4 oz. 50 cts.; oz. $\$ 1.50$.

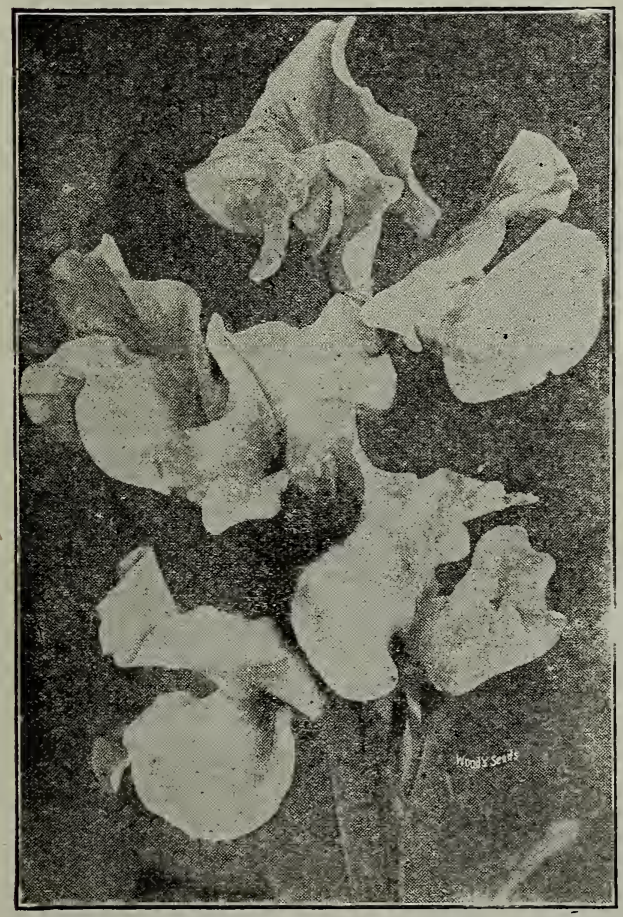

\section{Wood's Giant Sweet Peas}

AN OUNCF SOWS

Fall Sowings Give Earliest Blooms and a Longer Blooming Season

In November or December plant 4 to 6 inches deep riving and they will become well rooted and grow off at the first giving slight protection yield an abundance of bloom earlier and longer than if planted in the spring. Use plenty of Fell-rotted manure and don't gather the blooms grudgingly-the more you pick them, the longer and better they will bloom.

\section{SPENCER VARIETIES}

AIIs VARIFTIES-Plt. $10 \mathrm{cts.;} \mathrm{oz.} 30 \mathrm{cts.;} 1 / 4 \mathrm{Ib} . \$ 1.00$.

Afterglow.-Standard violet blue shading. Iing Edward Spencer. - The best pure to rosy amethyst; wings electric blue. red Spencer; nearly two inches across fine cut flower: an exquisite variety

Captain of the Blues (Pure Purple).

The margin of the petals is marbled.

Countess Spencer.-Soft rose-pink, shadin deeper at the edges.

Gladys Unwin.-Large bold bright pink. The grandest of all pink varieties. with bright orange standard.

zing white.-A perfectly finished unusu ally large pure white.

IILargaret Atlee.-Apricot pink on cream ground; a larger flower.

Masterpiece. - Lavender; flowers extra large and wavy.

Nubian.-Beautiful rich deep chocolate; fine waved flower of unusual size.

\section{GRANDIFLORA VARIETIES}

AII VARIgrrEs-Pkt. 5 cts.; oz. 12 cts.: 1/4lb. 35 cts.; 1b. $\$ 1.25$ postpaid. Apple Ilosscm (Deep Pink). - Standard Iads Grisel Hamilton (Lavender).-Best crimson pink, shading lighter at edges; wings white shaded with pink.

Black Knight. - Deep maroon, almost black: large size, open form.

Coccinea (Red).-Bright cherry red or cerise. $A$ distinct new shade.

Dorothy Isckford (Pure White).-Beautiful shell-shaped flower, extra large.

Flora Norton (Lavender Blue). A clea bright blue, with faint tint of purple. Fon. IIrs. E. Kenyon (Primrose).-Dee primrose yellow; extra large flower. ring mdward VII (Crim

of the lavender varieties; extra large

Iord Nelson (Navy Blue).-A fin

miss willmott (Orange Pink).-Riches orange pink, delicately shaded with

rose. Changes to rich bluish purple; extra large.

Prima Donna (Pink).-A clear and soft shade; three flowers to the stem.

Queen Alexandra (Scarlet).-The nearest scarlet in sweet peas; magnificent large flower.

\section{Sweet Peas in Mixtures}

\section{Wood's Superb Spencer Mixture}

-The newest introduction in sweet peas, differing from the old type in having waved or fluted standards. The stems, 12 to 14 inches long, usually bear 3 or 4 blooms which, under favorable conditions, measure two inches across. Pkt. $10 \mathrm{c}^{+-}$. measure cts.; $1 / 1$ lb. 50 cts.: 1b. $\$ 1.75$ postna' Perennial or Everlasting Sweet Peas.after year, bearing magnificent clusters of flowers. Mrixed colors, pkt. $10 \mathrm{cts}$.
Wood's Special Mimanre -A peerless grandiflora varieties and absolutely the
finest that can be made. A blend of the best sweet peas in cultivation; no dull colors, all choice giant-flowering varieties of everv cnlor and tvpe. the colors being evenly distributen throughout. In diversity of colnr. size and beauty of flowers sity of colnr. size and beauty of fowers no other grandiflora sweet pea mixture can surpass our "Special Mixture." Pkt.
5 cts.; oz. 15 cts.; 1/41b. $40 \mathrm{cts}$; ib. $\$ 1.25$ postpaid.
Large Flowering Mixed -A very good the old varieties; will give a good display throughout the season. Plkt. 3 cts.; oz. 8 cts.; 1/41b. 25 cts.; 1b. 85 cts. postpaid.

Cupid Sweet Peas - Distinct from othhigh and forming er sorts; 6 to 9 ins. Very neat, compact, bushy, with flowers as large and fragrant as the tall kinds. as large and fragrant as the tall kinds.
Fine for pots, borders and masses. Mixed Fine for pots, borders and masses. Mixed
colors, pkt. 5 cts.; oz. 15 cts.; 1/41b. 50 cts. colors, pkt. 5 cts.;
1 b. $\$ 1.50$ postpaid. 
Compressed Air Sprayer -A self-operating, strong, dura-

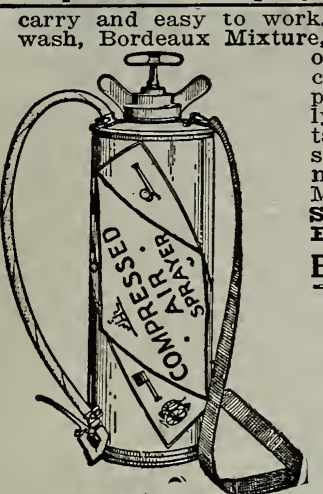
It will handle water-paint, whiteParis Green, Arsenate of Lead and charged by a few strokes of the plunger and two pumpings will usually discharge the entire contents of the tank. Capacity, 3 \% gallons; automatic shut off nozzle; valves all metal. Do not use galvanized tank for Bordeaux Mixture and lime-sulphur. Galvanized Steel Tank, $\$ 6.50$; Brass Tank, $\$ 10.00$. Ixtra Nozzles, \$1.50 each.

Bucket Spray Pump - E x cepting and handle, all parts are made of brass, preventing $\mathrm{d}$ a $\mathrm{m}$ a $\mathrm{g} e$ from spraying solutions. The air chamber space is large, insuring an even pressure; the valves are of ample size. Excellent for whitewashing and disinfecting stables and poultry houses; for washing $w$ in dows and vehicles; putCompressed Alr Sprayer

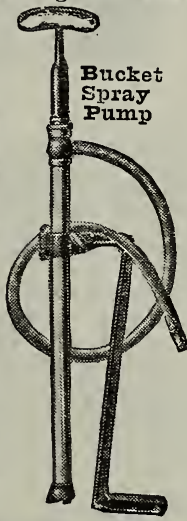
mail postpaid, $\$ 4.25$. By express, $\$ 4.00$.

4-foot extension pipe, for reaching into trees and inaccessible places, $50 \mathrm{cts}$. postpaid. BJ express, $40 \mathrm{cts}$.

Hand

\section{Sprayer}

-Very useful in small gardens, greenhouses, for spraying house plants, poultry houses, etc., applying liquids in a fine mist, with no waste. Distributes $\mathrm{S} l \mathrm{u} \mathrm{g}$ Shot, Paris Green and similar dry powders perfectly. By mail postpaid, 65 cts. By express, 50 cts.

\section{Continuous Sprayer}

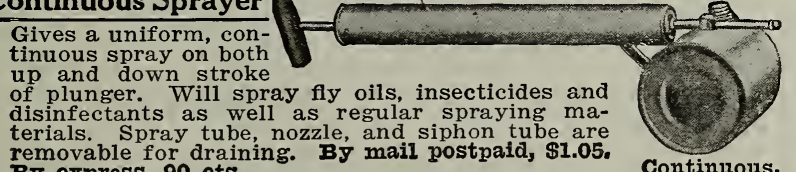
By express, 90 cts.

\section{Wheelbarrow Spray}

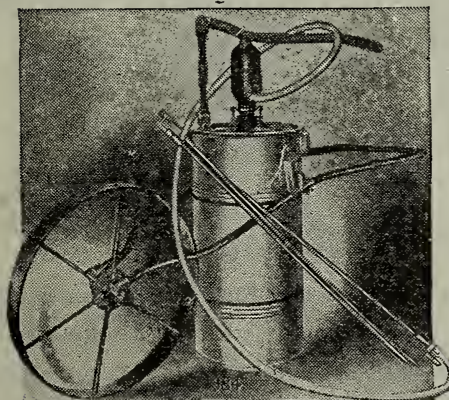

Pump -An ideal outfit for orchards, poultry plants, white - washing, applying cold water paint, etc. The pump has $1 \frac{1}{2}$ inch brass plunger, brass ball valves, mechanical agitator, lever shut-off, Vermorel nozzle, $8 \mathrm{ft}$. of hose and 8-ft. extension pipe. The galvanized steel tank holds 1
gals. Complete, $\$ 21.50$.

Auto Spray No. 5

A combination knapsack and bucket pump that will throw any kind of -spray

Wheelbarrow Spray Pump.

from very fine mist to a solid stream. The pump is brass, practically indestructible and will generate 180 lbs. pressure By detaching hose from tank and aching hose from tank and attachfirst-class bu cket pump. first-class bucket pump. Fine for applying wh it ewash, water paint, insecti-
cides and disinfectants.

Knapsack Outfit-Pump, tank, $3 \frac{1}{2} \mathrm{ft}$. of hose, extension pipe and strainer. Price, $\$ 8.50$.

Bucket Outfit - Same as the above, but without tank. Price, $\$ 6.00$.

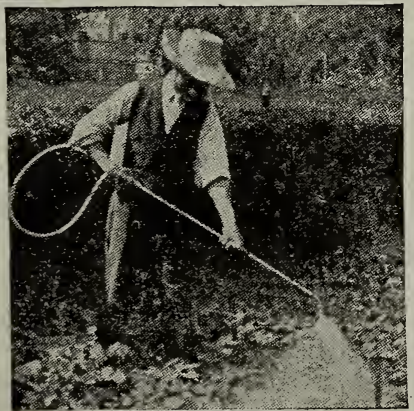

Auto Spras TO, 5.

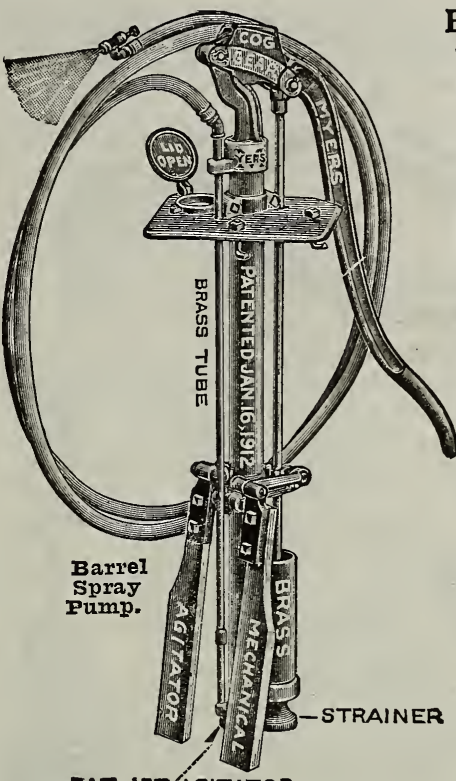

PAT JET/AGITATOR

\section{Barrel Spray Pump}

valves

and brass seats; the plunge is brass with hemp packing. the cylinder and discharge plpes are brass-these spray cliemicals. The air chamber is 32 inches lons. insuring a uniform, constant spray. Has good leviy operated. It is built $s$ that the entire pump set inside the barrel, the working parts are submerged in not praying liquid and does necessary to make an $8 \times 8$ opening in the head of th barrel, bolt in the pump and it is ready for work.

Outfit A. - Pump with me chanical agitator, 15 fee of $1 / 2$-inch hose, 8-foot extension.

Outfit B. - Pump with me chanical agitator, 2 leacls of $1 / 2$-inch hose (15 feet each), $Y$ connection, 28 foot extension pipes an

Nozzles, Hose, \&c. BORDEAUX NOZZLE. Throws a solid stream or a fine mist, or mav be shut by mail, postpaid, $\$ 1.05$.

VFRMIOREI NOZZI,E.-Made with spring degorger for removing obstructions. $\$ 1.00$ each; by mail, postpaid, $\$ 1.05$.

RUBBFR HOSF.- $3 / 8$-inch (for bucket pump) 16 cts. per foot;

1/2-inch (for barrel, Auto Spray No. 5, compressed air and wheelbarrow sprayers), 18 cts. per foot.

CranrPs for attaching hose, $3 / 8$ and $1 / 2$ inch sizes, $10 \mathrm{cts}$. each. COUPIINGS, male and female, $30 \mathrm{cts}$. each; by mail, $33 \mathrm{cts}$.

Feeny Dust Gun -Double acting, and applies all dry pow-
C)
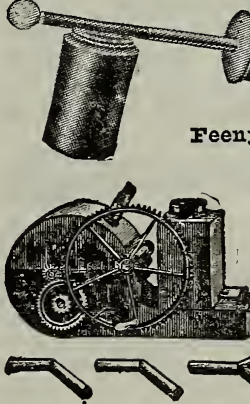

cides uniformis on two rows at that reases the plant. So light and easily worked that a child can operate it. By mail postpaid, press, \$2.50. plant and on both sides of the leaf. Price, $\$ 9.75$.

\section{Asparagus Buncher}

-Adjustable to size of

bunch and length of stalk.

Makes bunches 4 to $5 \frac{1 / 2}{2}$

inches in diameter, 8 to

12 inches long. $\mathbf{B Y}$ mall

postpaid, $\$ 3.60$

press, \$2.75.

Asparagus Knife 15 ins: the blade 11/2 inches wide.
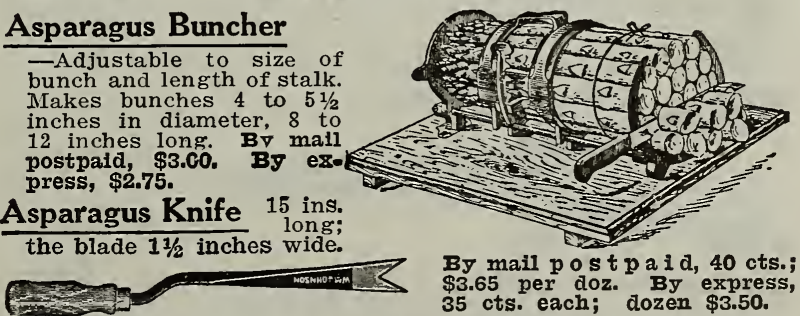

By mail pos t p a id, 40 cts.; $\$ 3.65$ per doz. By expres

Jute String -For tying up vegetable bunches, tomato plants, cannot now be had. By mail postpaicl, 35 cts. per lb. By express, 30 cts. per ib.; 5 lbs. for $\$ 1.35$.

Jacket Cans - We buy in carload lots; you get the benefit of 1-gal. size, 40c; 2-đal. 50c; 3-gal. 60c; 5-gal. 75c; 10-gal. \$1.25, 


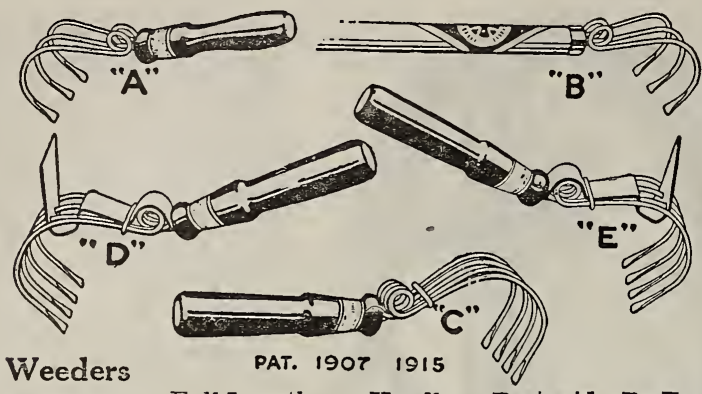

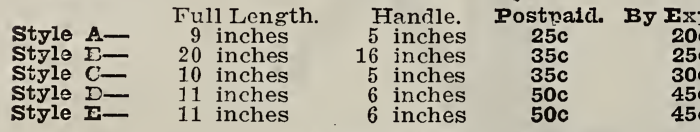

Lang's Hand Weeder

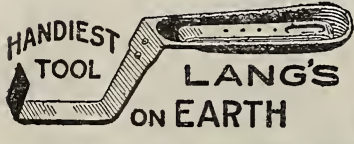

-A real labor saver:

fits the hand nicely:

lasts for years. $\mathrm{BJ}$.

by express, 20 cts.

Mole Tran set e 1 f-

The spears are made of spring steel and will pier

the mole easily; thorou ghly tinned to prevent rust-

Three Tine

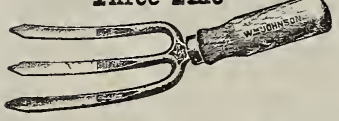

Spading Forks 3 Fine.

vell made $\mathrm{r}$ on $\mathrm{g}$ and

ished; hardwood han-

dle; length, 11 inches. By mail postpaid, 35c; by express, 30c.

4 TINr.-A good and serviceable fork, mail postpaid, 25c; by express', 20c.

\section{GARDEN TROWELS}

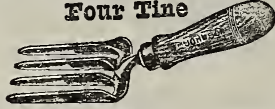

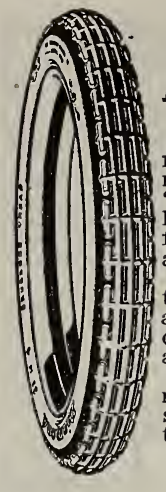

\section{Diamond Tires}

A. Good Tire with a Good Name at a Iow Price, with Adjustments Made on a 6,000-Mrile Basis.

DIAMOND TIRES have an established national reputation and are the most popular of all makes more than 2,000,000 being in use daily. They are not "cheap," but are economical, the first cost being the lowest of any standard tire; they are guaranteed free from imperfections in material and workmanship, and adjustments are made on a 6,000-mile basis.

DIAMOND GRAY INNER TUBES are made from tough, gray rubber that has wonderful wear-resistance, retain their life and elasticity for thousands of miles-in practice, for years-and for thousands any number of times and still give perfect pe patched Our firm uses twenty-three auto-trucks service. Our firm uses twenty-three auto-trucks and automobiles. Using so many enables us to buy in wholethe benefit of our large purchases.

Iet Your Next Tire Be a Diamond

\section{Retail Price Our Price}

War Tax including

not included. War Tax.

$30 \times 3 \quad$ Smooth........ $13.20 \quad 11.85$

$30 \times 3$ Non-Skid ........ 15.10

$30 \times 31 / 2$ Non-Skid........ 19.15

$32 \times 31 / 2$ Non-Skid......... 22.40

$31 \times 4$ Non-Skid ........ 29.95

$32 \times 4$ Non-Skid......... 30.45

$33 \times 4$ Non-Skid......... 32.00

3.x4 Non-Skid......... 32.65

13.50
17.20
20.00
26.75
27.25
28.65
29.30

By Exp. Tubes

\section{PLANET JR. GARDEN TOOLS}

Do you work your garden with an old-fashioned hoe or with modern tools like a Planet Jr.? If you could see one at work no argument would be necessary to convince you that you just had to have one. We have used them for more than thirty years and cannot see how we could do without them.

\section{DRILLS}

No. 3 Drill sows at any desired depth in continuous rows or plants in hills $4,6,8,12$, or 24 inches apart, covers, rolls, and marks the next row all at a single operation. Price, $\$ 18.00$.

No. 4 Drill opens the row, plants the seeds either in continuous rows or in hills $4,6,8,12$ or 24 inches apart; covers the seeds and marks the next row at one operation. The drill can be detached from the frame and the working tools attached2 hoes, 3 cultivator teeth and a plow. Price, $\$ 19.00$.

No. 31 Drill plants in drills any depth you like, and like No. 4 the drill can be detached when you want to cultivate. The cultivating attachments are a cultivating ste $\in \mathrm{l}$ to open rows, a 5-prong cultivator for deep or shallow work; 2 sweeps of different widths and a large plow. Price, \$12.50.

\section{CULTIVATORS}

No. 38. Single wheel Cultivator and Plow. $\mathrm{H}$ a s a large plow, 2 sets of discs for cultivating and a pair of $3-\mathrm{prong}$ cultivator teeth. A fine outfit for the Price, $\$ 8.00$.

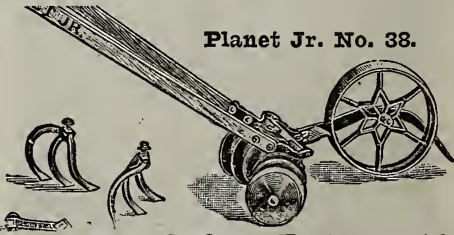

To. 16. Single Wheel Cultivator, Rake and Plow. Equipped with a pair of 6 -inch hoes, 3 cultivator teeth, a large plow; 4 -inch and 7 -inch rakes and leaf guard. A splendid combination. Price, $\$ 10.00$.

No. 17. Single wheel Hoe. Exactly like No. 16, but has no rakes. Price, $\$ 8.25$.

No. 19 Garden Plow and Cultivator. Has a cultivating tooth for deep work, a 10 -inch sweep for
shallow work, a 5-prong cultivating attachment and a plow. Price, \$5.75.
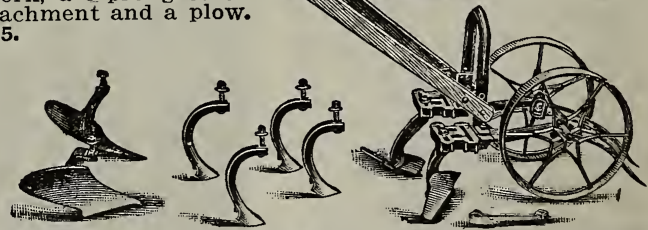

No. 12. Double and Single wheel Foe. Will straddle the row and work both sides at once, or between the rows as you prefer. Has 2 hoes, 4 cultivator teeth, a pair of plows and 2 leaf lifters. Price, $\$ 12.00$.

Fire Fly Garden Plow. An exceedingly useful tool in the small garden and chicken yard. Price, $\$ 3.50$.
MOSS For florists and for shipping plants. 65 cts.; 10 lbs. $\$ 1.25$. By freight or express, ib. $12 \mathrm{c}$; 5 ibs. for $50 \mathrm{c}$; bale, $\$ 3.50$. blade with notch for cutting smal branches. Blades express, \$2.50.

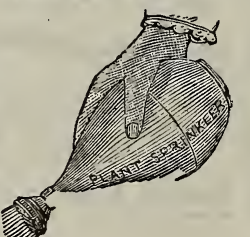


PRICFS FIUCTUATS. The prices named below are our prices at this date. Price of Poultry Foods are always subject to market fluctuations. We alwajs fill all orders entrusted to us at lowest ruling prices on date order is received.

Wood's Poultry Grain Food This mixture contains everygrown fowls-wheat, barley, oats, cracked corn, kaffir corn, ground bone and oyster shell, making a complete food, specially recommended for poultry and laying hens at all seasons. Price, 50 lbs. $\$ 2.10 ; 100$ lbs. $\$ 3.90$.

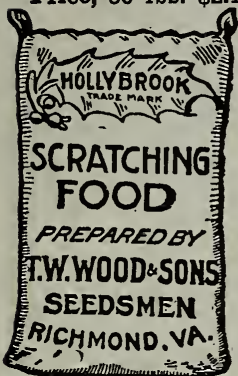

Hollybrook Scratching Food $\underset{\text { mixture }}{- \text { This }}$ contains a large assortment of cracked and small grains to be used as an exercise food, scattered in the pens to make $50-1 \mathrm{~b}$. bag, $\$ 2.20$; $100-1 \mathrm{~b}$. bag, $\$ 4.20$.

Wood's Scratch Food -An excelient rious grains properly balanced and contains no grit or oyster shells. Price, 50-1b. bag, \$2.10; 100-1b. bag, \$4.80.

Hollybrook Forcing Food - This food prepared for forcing growth, so as to produce early broilers and roasters

Hollybrook Growing Food -A dry mash food growth of bone and muscle. Price, 50-1b. bag, $\$ 1.95$; $100-1 \mathrm{~b}$. bag, $\$ 3.65$.

Hollybrook Developing Food - This is a spefor properly maturing the young chicks after they are ready to be weaned from ch

Hollybrook Laying Food is a good balanced rathe morning mash containing all the elements necessary for egg production, and will give most satisfactory r

Hollybrook Pigeon Mixture Containing Cracked Corn.Field Peas, Hemp and other grains, especially prepared for pigeons. 50-1b. bag, $\$ 2.40$; $100-1 \mathrm{~b}$. bag, $\$ 4.65$.

Containing no Corn, at \$4.85 per 100 lbs.

Hollybrook Chick Food -A complete scientifically c o m Prepared so as to fully nourish and sustain the young chicks from the time of hatching until they are fully developed. Price, 50-1b. bag, \$2.25; 100-1b. bag, \$4.35.

Hollybrook Rabbit Food -Rabbits, like other animals, remaintain health; that is, consisting of some green stuff or roots and some grain We put up three mixtures approved by and some grain. We put up three mixtures approved by oats, barley and wheat. One for breeding does, to be used one meal a day with the general purpose feed and green stuff, consisting of corn meal, barley meal, oatmeal and bran, to which can be added a small proportion of tea leaves after they leave the table, and one for young rabbits consisting of cracked corn cracked barley, and bran. Care should be taken that green feed given young rabbits is not.wet when fed and not fed too liberally. If there is a shortage of green feed, we recommend feeding Alfalfa meal, which we can supply. Prices:

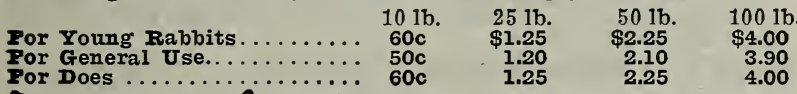

For Does .............. 60 Crushed Oyster Shells - It is needless

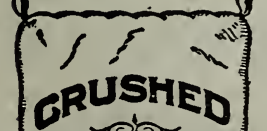

upon the poultryman the value of Crushed Oyster Shells for poultry. Every poultryman realizes their importance as an eggshell maker and general promoter of good health. These oyster shells are thoroughly th. OYSTER SHELLS for POULTRY

MANUFACTURED FOR T.W.WOODESONS RICHMOND.VA. We can offer these oyster shells in two sizes-poultry size and chick size.

POUITRY SIZE-15 1bs. $30 \mathrm{cts.;} 50 \mathrm{lbs}$. $70 \mathrm{cts} . ; 100$ lbs. \$1.15.

CFICK SIZE-15 lbs. $30 \mathrm{cts}$; 50 lbs. 70 cts.; 100 lbs. \$1.25.

Mica Spar Cubical Grit - No poultryto be without grit, as the health of your poultry depends upon their digestion. Mica Spar Cubical Grit is composed of Lime and Iron, and is one of the best grits known. Put up in
three sizes. Price: 5 lbs. 25 cts. 25 lbs. 50 cts.; 50 1bs. three sizes. Price: 5 lbs. 25 cts.; 25 lbs. 50 cts
30 cts.; 100 lbs. $\$ 1.45$. Special price in 500-1b. lots.

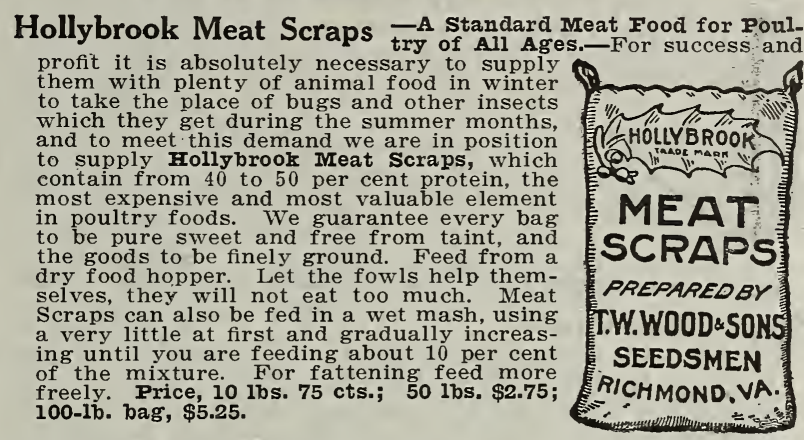

Darling's Meat Crisps trate for poultr contain 75 per cent protein and under any condition where ground grain will remain in three sizes-fine, medium and coarse. Price postpaid, 3-1b. pkg. 45 cts.; 61/2-1b. pkg. 88 cts. Price, by express, $3-1 \mathrm{~b}$. pkg. $35 \mathrm{cts}$; $61 / 2-1 \mathrm{~b}$. pkg. $70 \mathrm{cts}$.

Blood Meal - If you want eggs in the winter and highest prices, you must feed animal food. For this purpose Blood Meal is unexcelled as an egg producer; will make your hens lay, your chicks grow fast, and keep your fowls healthy: Should be mixed 25-1b. bag, \$2.50; 50-1b. bag, \$4.75; 100-1b. bag, \$9.25.
Poultry Bone - Made from fresh green bone from which the ing. moisture and grease have been extracted, leavmixed with cornmeal or bran and fed every other day; on alternate days use meat scraps or blood meal. State bag, 70 cts.; 50-1b. bag, $\$ 2.75$; 100-1b. bag, $\$ 5.00$.

Green Cut or Mealed Alfalfa is one of the best green foods eqo-production, it is should be fed. Price, 50-1b. bag, $\$ 1.45 ; 100-1 \mathrm{~b}$. bag, $\$ 2.75$.

Pin Head Oats $T$ This steel-cut oat is of a very high nutrivaluable as a bone and muscle maker for young chicks. The oat is first hulled and then cut to a desirable size for feeding. $100-1$ b. bag, $\$ 6.00$.

CRACKID CORN-50-1b. bag, \$1.90; 100 lbs. \$3.65.

KAFFIR CORN $-50-1 \mathrm{~b}$. bag, $\$ 1.95 ; 100 \mathrm{lbs}$. $\$ 3.65$.

CANADA TIEID PEAS, $-50-1 \mathrm{~b}$. bag, $\$ 3.70 ; 100$ lbs. $\$ 6.50$.

WHTTE OATS FOR SPROUTING.- $\$ 1 . C 0$ per bushel.

FIAX SEED.- Per 1b. $10 \mathrm{cts.;} 50-1 \mathrm{~b}$. bas, $\$ 3.75 ; 100$ lbs. $\$ 7.25$ SUNFIOWER,-Ib. $25 \mathrm{cts}$; $10 \mathrm{lbs}$. for $\$ 2.25$; $\$ 20.00$ per $100 \mathrm{lbs}$. TMTPORTED INIIIET_LIb. $10 \mathrm{cts.;} 10 \mathrm{lbs}$. $20 \mathrm{cts}$; $100 \mathrm{lbs}$ \$7.00. Hrip - $14 \mathrm{cts}$; 10 lbs. for $\$ 1.20$.

BUCKW HEAT.-Bushel (48 lbs.), \$2.30.

Charcoal -No poultry raiser out charcoal. It aids digestion, purifies the blood and promotes the health of the chickens to a wonderful ex-Grade A (fine granulated) for use in mash mixture; Grade $B$ (m ed i u m granulated) for small newly hatched to halfgrown chicks. Grade C (coarse granulated) for fowls. Put up in $2-1 \mathrm{~b}$. paper cartons and $50-$ 1b. paper-lined bags. Postpaia, 2-1b. cartons, 25 cts.; $\mathbf{B y}$ ex: press, 2-1b. cartons, 20 cts.; 50-1b. paper-lined sacks, $\$ 2.00$. I have been using Hollybrook Chick Feed and Hollybrook Forcing Feed

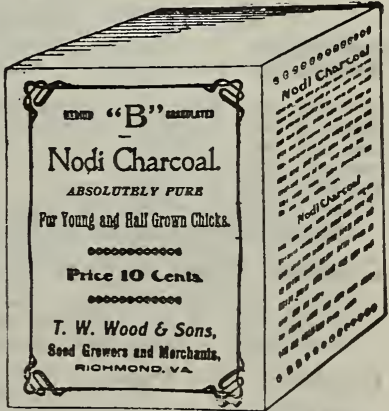
for four years, and I consider them North Carolina, April, 1919. 


\section{STERLING POULTRY REMEDIES}

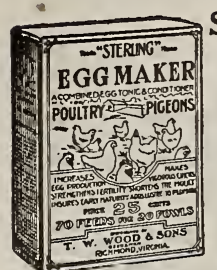

Sterling Egg Maker - This is a meat food that makes hens lay. It is compounded according to a scientific formula and contains animal protein and nitrogenous extracts in a highly concentrated form. This condimental food takes the place of insect life, when bugs, worms, etc., which are natural animal food, cannot be obtained. It will shorten the moulting period, bring on an early egg production and keep up the fowl's strength. At first feed every day at the rate of two table spoons to a quart of meal or wet food, afterward two or mence laying freely it can be discontinued. PRICE, 21/2-1b. pkg. 35 cts. POSTPAID. BY IXPRESS, $2 \frac{1}{2}-1 \mathrm{~b}$. pkg. $25 \mathrm{cts}$. Sterling Lice Powder This preparation is carefully comor other chemicals which will injure the fertility of the eggs. It is easy to apply, sure in effect, and can be used in the nest of setting hens without injuring the young chicks or eggs. Vermin will weaken the fowl and make them susceptible to all diseases, which reduces the egg production, also the vitality. For lice on cattle and fleas on dogs, Sterling Iice Powder is a 15-0z. box 33 cts.; 48-oz. box 62 cts.; 100-0z. box \$1.20. PRICE BY EXPRESS, 5-oz. box 10 cts.; 15-oz. box 25 cts.; 48-0z. box 50 cts.; 100-0z. box $\$ 1.00$.

Sterling Liquid Lice Killer Sterling Lice Paint is a sciention for killing lice, mites and their parasites on fowls, but which also does excellent execution on lice and ticks on sheep,
hogs, horses and cattle. For poultry it is simply used by sprinkling or spraying on the roosts, which form a vapor or gas of the same weight as the air, which hovers about the bodies of the fowls while they sleep, penetrating the feathers and killing all the insects there. Directions for use on each; can. Pal. can \$1.10 BY EXPRESS.

Sterling Disinfectant Is unexcelled for disinfecting poultry toilet or any place where a good germ or odor destroyer is needed. 0 -qt. can $60 \mathrm{cts}$; $1 / 2$ gal. $\$ 1.00 ; 1$ gal. $\$ 1.75$, BY EXPRESS.

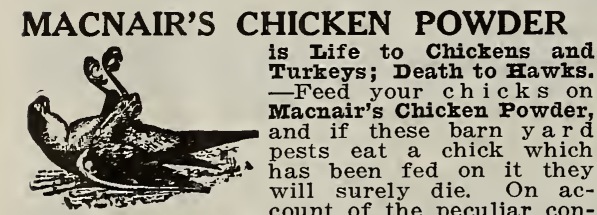

struction of the stomachs of these animals,

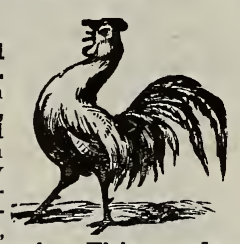
what is life to chicks and turkeys is death to hawks. This powder is a medicine that gives wonderful results in safeguarding against and curing Cholera, Gape, Roup, Limber Neck, IndigesIarge package (not mailable), 35 cts. BY EXPRESS.

HACKETT'S GAPE CURE this deadly disease It is for given internally, but simply dusted over the chicks and thev POSTPAID, 41 cts. each. PRICE BY EXPRESS, 35 cts. each.

\section{CYPHERS POULTRY REMEDIES}

Remedy No. 1.-For Bronchitis. No. 3. charge from eyes.

Remedy No. 5.-For Chronic Roup and all forms of Canker.

Remedy No. 7.-For Ulcers and Diseases of the Skin.

Remedy No. 7.-For Ulcers and Diseases of the

Remedy No. 9.-For Worms.

Remedy No. 10.-For Diseases of Egg Organs.

PRICE POSTPAID, 27 cts. each; BY IXPRESS $25 \mathrm{cts}$. each.

Cyphers' Lice Powder ing excellent preparation for killPAID, 5-oz. box 16 cts.; 15-oz. box 31 cts.; 48-oz. box 62 cts. 100-0z. box \$1.20. PRICE BY FXPRESS, 5-oz. box 10 cts. 15 oz. box 25 cts.; 48-0z. box 50 cts.; 100-0z. box $\$ 1.00$.

Cyphers' Lice Paint 2 - For painting roosts. 1-qt. can 25 cts.; FXPRESS.

Napcreol 50 cts. ; 1 gal. \$1.50 BY rXPRESS, etc. 1-qt. cans,

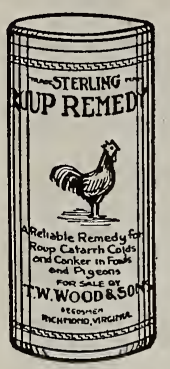

Sterling Roup Remedy - Roup is a deadly disits early stages with the use of our Sterling Roup Remedy, you will prevent much loss among your poultry. When first you detect any signs of frothiness or bubbles in the corner of the eyes, or sneezing snuffles, or a water discharge from the eyes and nostrils, you should not lose time in separating these fowls from the rest of the flock. PRICE POSTPAID, small size, 31 cts.; large PRESS, small size, 25 cts.; large size, 50 cts.

\section{Sterling Cholera Remedy}

- Sterling Cholera Remedy is one cholera in all its forms and stages. Cholera is the most deadly disease affecting poultry, therefore every poultryman should take every precaution to keep his fowls free from this disease. This is put up in powder form, so it can be given to the fowls very easily by putting it in their PRICE BY EXPRESS, $50 \mathrm{cts.}$

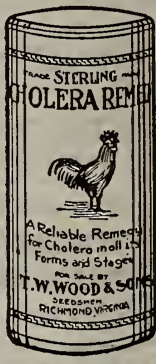

Sterlingworth Diarrhoea Remedy A guaranteed remedy young chicks and for dysentery, diarrhoea and all bowel troubles in full-grown fowls. It is the old original White Diarr-

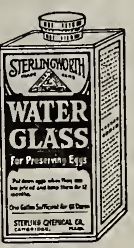
hoea Powder. It is used in the drink of the fowls and chicks. They take their own medicine. We know of nothing to equal it. Keep the remedy on hand and use some in the "little fellows" "drink when they are two days old. PRICE, trial size 25 cts. POSTPAID; box sufficient for several flocks 50 cts. POSTPAID.

Sterlingworth Water Glass This preparation is for preserving eggs. Eggs put down in this solution will keep fresh for ten months. One gallon makes sufficient solution for 50 dozen eggs. Price: 1-qt. can $40 \mathrm{cts}$. each; 1-gal. can $\$ 1.00$ each.
Rust Haven's Climax Condition Powder A splendid preand cure for cholera and other poultry diseases; it tones up the system and greatly improves the plumage after the trying moulting season. Also a good medicine for hogs, cattle and horses. PRICE POSTPAID, 13-oz. pkg. 33 cts.; 32-oz. pkg. 60 cts.; 5-1b. pkg. \$1.18; $8-11$. pk. pkg. 50 cts.; 5-1b. pkg. $\$ 1.00$ 8-1b. pkg. \$1.50; 20-1b. pkg. \$3.50.

Rust's Soluble Roup Powder -An excellent remedy for fowls and pigeons. PRICE POSTPArD carrh, colds, etc., of 9-0z. box, 56 cts.; 20-oz. box, \$1.08. PRICF BY IXPRISS, 4-oz. box, 25 cts.; 9-0z. box, 50 cts.; 20-oz. box, $\$ 1.00$.

Rust's Havens Roup Pills these pills act directly upon me glands and mucous membrane, allay all tendency to fever and carry off all morbid matter from the system. PRICE POSTPAID, 50 pills in box, 31 cts.; box of 112 pills, 56 pills, 25 cts.; box of 112 pills, $50 \mathrm{cts}$.; box of 250 pills, $\$ 1.00$.

Rust's Lice Killing Powder -Contains no naphthalene or does not affect the flavor of eggs or injure them for hatching when fowls or nests are dusted with it. Directions on each bOX. PRICE POSTPAID, 5-0z. box $16 \mathrm{cts.;} \mathrm{16-0z.} \mathrm{box} 33$ cts.; 48-0z. box 62 cts. PRICE BY FXPRESS, 5-0z. box 10 cts.; 16-oz. box 25 cts.; $48-0 z$. box 50 cts.

Rust's Liquid Lice Killer is an instantaneous disinfectant. vermin and bad odors. 1-qt. cans 35 cts.; 2 -qt. cans 60 cts.

CARBOLA The Disinfectant that Paints. Carbola is infinitely fecting qualities it ever had by slacking when exposed to the air. Very much better than kalsomine or whitewash because it paints just as clean and bright a white, but will not chip, scale or peel off. Can be applied with either sprayer or brush. Trial pkg., postpaid, 35 cts., by express 25 cts.; 10-1b. pkg. by express $\$ 1.00 ; 20-1 \mathrm{~b}$. pkg. by express $\$ 2.00 ; 50-1 \mathrm{~b}$. pkg. $\$ 4.00$. POULTRY MUSTARD - Improved digestion means greattity of food: this means more egrs. mustard, but is prepared for poultry alone. Feed a teaspoonful for every six fowls; mix with dry meal, then add water. Price, by express, 11/2-1b. pkg. 40 cts.; 3-1b. pkg. $70 \mathrm{cts.;} \mathrm{5-1b.} \mathrm{1)kg.}$ $\$ 1.10$; 10-1b. pkg. \$2.00; 25-1b. pail, $\$ 4.50$. 


\section{CONKEY'S POULTRY REMEDIES}

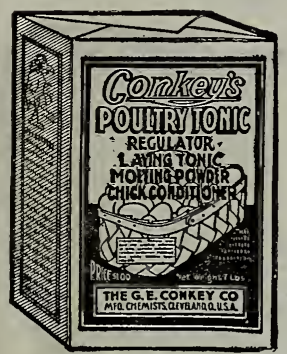

Conkey's Poultry Tonic A high qualmaker, and regulator, good for young and old birds all the year. Contains no filler-and no cayenne pepper or other harmful ingredient. Helps nature do its work in a natural, normal way. Does not over stimulate. PRICE, POSTPAID, 11/2-lb. pkg. $38 \mathrm{cts}$.; $31 / 4-1 b$. pkg. 72 cts.; 12-1b. pail, $\$ 1.70$. PRICE BY FXPRIFSS, 11/2-1b. pkg. 30 cts.; $31 / 4-1 b$. pail, $\$ 2.75$.

\section{Conkey's Scaly Leg Remedy}

-A penetrating salve that rapidly destroys the mites causing the scaly growth. Also desirable for brightenin.
birds. up the legs of show birds.

Conkey's Head Lice Ointment -For destroying the murin tube form. PRICE POSTPAID, $15 \mathrm{cts}$. and $30 \mathrm{cts}$.

Conkey's Lice Powder -A particularly efficient preparation PRICE POSTPAID, 5-oz. pkg. 21 cts.; 15-0z. pkg. 36 cts.; PRICH POS 5-oz. pkg. 72 cts.; 100-oz. pkg. $\$ 1.60$ cts.; 48-0z. pkg. 60 cts. 100-oz. pkg. $\$ 1.20$.

Conkey's Lice Liquid -A powerful liquid for use in sprayof mites if used consistently. 1 qt. 50 cts.; $1 / 2$ gal. 75 cts.; 1 gal. \$1.25; 5 gals. \$5.50. IXPRISS EXTRA.

Conkey's Nox-i-cide -An all-round disinfectant, germicide insecticide Emulsifies in water actil quantity accomplishes remarkable results. Desirable for use in the house, poultry 1 gal. $\$ 1.75 ; 5$ gals. $\$ 7.50$. EXPRESS EXTRA.

Conkey's White Diarrhoea Remedy - To be given to young drink until they are three weeks old. Aids wonderfully in nreventing the development of this dread disease. PRICE, POSTPAID, small size $36 \mathrm{cts}$.; large size $66 \mathrm{cts}$. PRICE BY EXPRESS, small size $30 \mathrm{cts}$; large size 60 cts.
Conkey's Roup Remedy - Known to every poultryman. A reduces the swelling and brings the bird back to normal. Given in the drinking water. PRICE, POSTPAID, small size, $36 \mathrm{cts}$.; medium size, $66 \mathrm{cts.}$; large size, \$1.28. 'PRICE, BY EXPRISS, small size, 30 cts.; medium size, 60 cts.; large size, $\$ 1.20$.

Conkey's Bronchitis Remedy $-\vec{A}$ penetrating healing oil in the bronchial tubes. Stops the rattling and effort to breathe. PRICE, POSTPAID, $66 \mathrm{cts.;} \mathrm{PRICE,} \mathrm{BY} \mathrm{EXPRESS,} 60 \mathrm{cts.}$

Conkey's Cholera Remedy chor indigestion and so-called birds. Given in drinking water quickly overcomes the diseased, birds. Given in drin. PRICE, POSTPAID, small size 36 cts.; large size, 66 cts. PRICE, BY EXPRESS, small size $30 \mathrm{cts.}$ large size $60 \mathrm{cts}$.

Conkey's Chicken Pox (Sorehead) Remedy

Package contains salve for application on sores and a blood purifying tonic. Easily applied. PRICE POSTPAID, small size $36 \mathrm{cts}$; large size $66 \mathrm{cts}$. PRICE BY EXPRESS, small size 30 cts.; large size 60 cts.

Conkey's Gape Remedy -Consists of a sneezing powder a tonic for strengthening the entire system. PRICE POSTa tonic small size $36 \mathrm{cts}$; large size $66 \mathrm{cts}$. PRICE BY EXPREss, small size 30 cts.; large size, 60 cts.

\section{Conkey's Buttermilk Starting Food}

is a well balanced, carefully made food, that will bring results It supplies buttermilk to the chicks in dry form with only the water eliminated. The rich, pure buttermilk is mixed with a combination of clean, wholesome grains balanced just right for the sensitive organs as a preventative measure against disease; the buttermilk and grains make the chick grow wonderfully fast, solid the chick grow wonderfusTPAID, 1-1b. pkg. $23 \mathrm{cts}$; 3 -1b. pkg. $47 \mathrm{cts}$.; $61 \%-1 \mathrm{~b}$. pkg. 83 cts. PRICE, BY EXPRESS, $1-1 \mathrm{~b}$. pkg. 15 cts.; $3-1 \mathrm{lb}$. pkg. $35 \mathrm{cts}$;
$612-1 \mathrm{l}$. pkg. 65 cts.

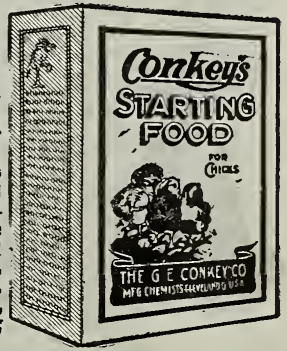

\section{EGG BOXES AND CARRIERS}

Metal Egg Crates For Shipping Fggs by Parcel Post.-These

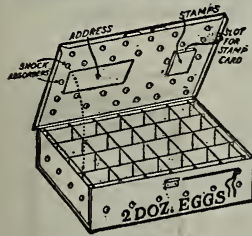
boxes are made for continued use bein very strongly constructed but light in weight. All crates are provided with built-in shock a bsorbers to give a require outside wrapping for malling. Each Each, Dozen, Capacity. Postpaid. By Exp. By Exp. 2-doz. size. 3-doz. size.... 1.10 4-doz. size..... 1.35 6-doz. size..... 1.87 .85
1.00
1.25 1.75

10.00 11.25 14.00
19.50

Parcel Post Egg Boxes These boxes structed that each egg is separated by a thickness of corrugated board, and the entire contents are surrounded by a double wall of air-cushioned c o r r u gated board. Absolute protection is theref,ore astured, as the box possesses sufficient strength and durability to stand the usual rough hand-

ling in transit.

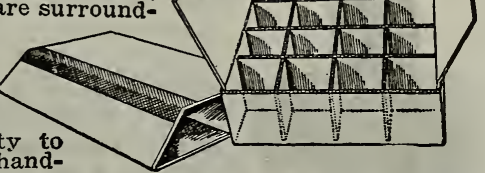

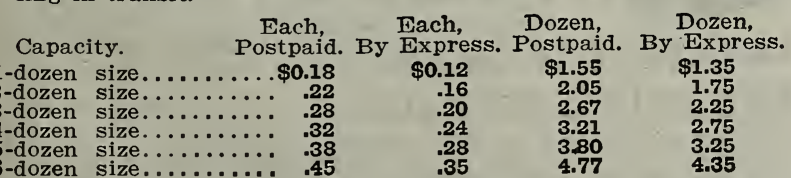

Eyrie Egg Boxes - Specially made for shipping or deliverma ing eggs for setting by express. They are

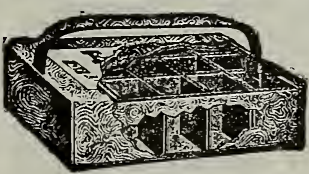
, which is the best packing which, while elastic, will not crush. The insertion of the handle automatically locks the box. The handle also prevents the putting of anything on top of the box, and provides a means of handling it, thus limiting the liability of rough usage by the express agent. These boxes packed weigh less than press rate to any point in the United States very low.

Each, Each, Dozen, Dozen,

Postpaid. By Express. Postpaid. By Expres
15-egg size.
$\$ 2.50$
$\$ 2.25$

Postpaid

$\$ .20$

\section{Humpty Dumpty Folding Egg Crate}

-A safe and convenient folding.

shipping crate for eggs. Made of

hard wood with wire rod through

corners and card board division

and filers. Fig. 1, fold 3 set up open fig 4 shows half doz. complete, ready for shipment.

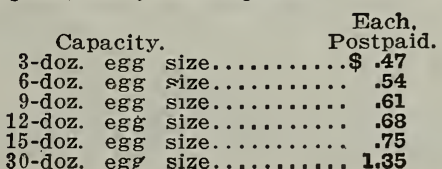
Each.

3-doz.

6-doz egr size. . . . . . . 54

12-doz. eg sim........... 68

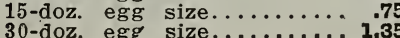

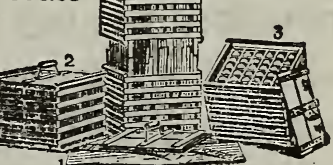

$$
\begin{array}{cc}
\hline \text { Fach, By } & \text { Per Doz, By } \\
\text { Express. } & \text { Express. } \\
\$ \$ 35 & \$ 3.50 \\
.40 & 3.75 \\
.45 & 4.50 \\
.50 & 4.75 \\
.55 & 5.00 \\
1.00 & 8.50
\end{array}
$$




\section{POULTRY FOUNTAINS AND FEEDERS} tary Feeding and watering Devices Insures Your ing Devices Insures Your

\section{The Duplex Fountains}

- The latest and most practical sanitary poultry fountain on the market. This is a double fount, easy to fill, and keeps the water clean and pure. Made in two size, $\$ 1.00$ each; 2-gal. size, $\$ 1.27$ each. Price by express, 1-gal, size, 90 ct

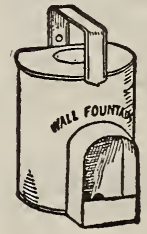

Standard Wall Fountains are made of the best will last many years with the proper treatment. It can be hung on wall of a building or against an upright post or board at any height. A hood projects over the water trough and prevents the water size $81 \mathrm{cts}$. : 1-gallon size 93 cts.; 2-gallon size S1.20: PRICE BY EXPREST, 2-qt. size $75 \mathrm{cts}$. 1-gallon size 85 cts.; 2-gallon size \$1.10.

\section{Drop Bottom Wall Fountains}

These drop-bottom drinking founts are nized steel. The bottom can be swung open with one hand, as it is secured by one spring in the front, while most founts have a spring on each side, requiring both hands to open; even then they are opened with considerable trouble. The bottom is made of solid brass, preventing possibility of rust or of breaking off. PRICE POST 2-qt. size 75 cts.
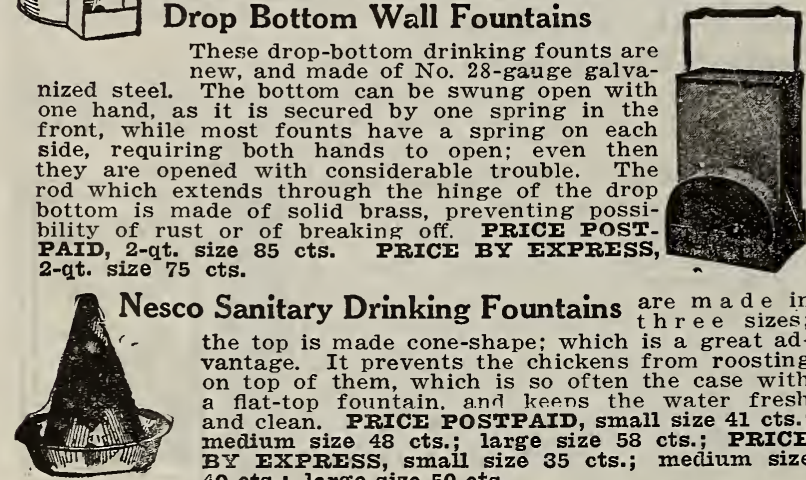
Sanitary Drinking Fountains are $\mathrm{m} \mathrm{a}$ vantop is made cone-shape, which is a great advantage. It prevents the chickens from roosting a flat-top fountain and keens the water fresh and clean. PRICE POSTPAID, small size $41 \mathrm{cts.;}$ medium size 48 cts.; large size $58 \mathrm{cts}$.; PRICE 40 cts.; large size $50 \mathrm{cts}$.

Peerless Wall Fountains are something new able in the way of poultry fountains. They are made with a detachable bottom which makes POSTPAID, 1-qt. size $46 \mathrm{cts}$.; 5 -qt. size $85 \mathrm{cts}$. 10-qt. size \$1.39. PRICE BY EXPRESS, 1-qt. size 40 cts.; 5-qt. size 75 cts.; 10 -qt. size $\$ 1.25$.
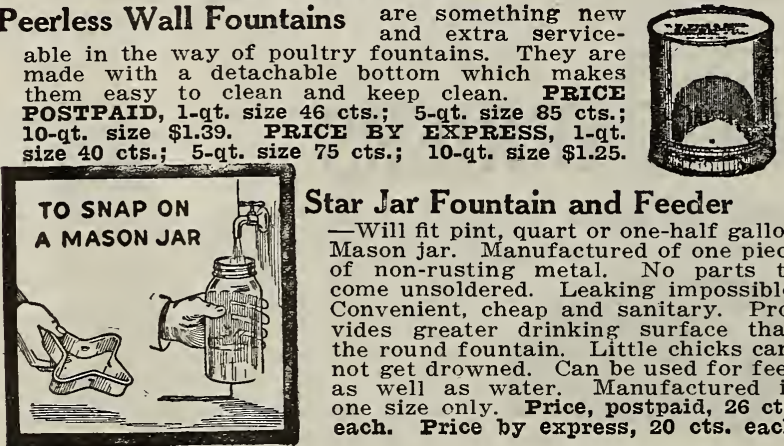

Star Jar Fountain and Feeder

-Will fit pint, quart or one-half gallon Mason jar. Manufactured of one piece Mason jar. Manufactured of one piece come unsoldered. Leaking impossible. Convenient, cheap and sanitary. Provides greater drinking surface than the round fountain. Little chicks cannot get drowned. Can be used for feed as well as water. Manufactured in each. Price by express, 20 cts. each.

GAPE WORM EXTRACTORS Then gape worms they must be extracted, if the chicken is to recover. The gape worms, if there are any, will be found, adherin
of the wind-pipe. PRICE, POSTPAID, $30 \mathrm{cts}$.

POULTRY KILLING KNIFE -Every poultry raiser who ket, either chickens, du cks geese or turkeys, should own
one of these knives. They are
mad ment steel and will last a lifetime. PRICE POSTPAID, 50 cts. I have used your Hollybrook Laying Food for the past two seasons, and have found it entirely satisfactory. Am feeding it to my White Orpingtons, and also using it on our R. I. Reds, which are kept on another farm. It is a great egg producer, and I expect to con
use-DR. JENNESS MORRILL, Pitt Co., N. C., April 25, 1919.

Your Hollybrook Chick Food has given me entire satisfaction. My chickens have thrived and done bettter this spring than I have ever had them to do. I also find your Conkey's White Diarrhoe.
Sexton's Dry Food Hopper

- This hopper is arranged to hang on the wall the desired distance from the floor. It is impossible to waste any feed, as the pan at the bottom takes any feed that may be picked out. The body being covered keeps the feed dust-proof clean and dry. Made of galvanized iron, and the grating is of round galvanized wire, preventing the poultry from cutting their bills. Price, 12-qt. size $\$ 1.50$ each by express.

\section{JUNIOR CHICK FEEDER}

-A simple, practical and sanitary feeder for little chicks. Note shape of feeding spaces-the chick can feed with ease, but cannot get inside. By the use of this feeder
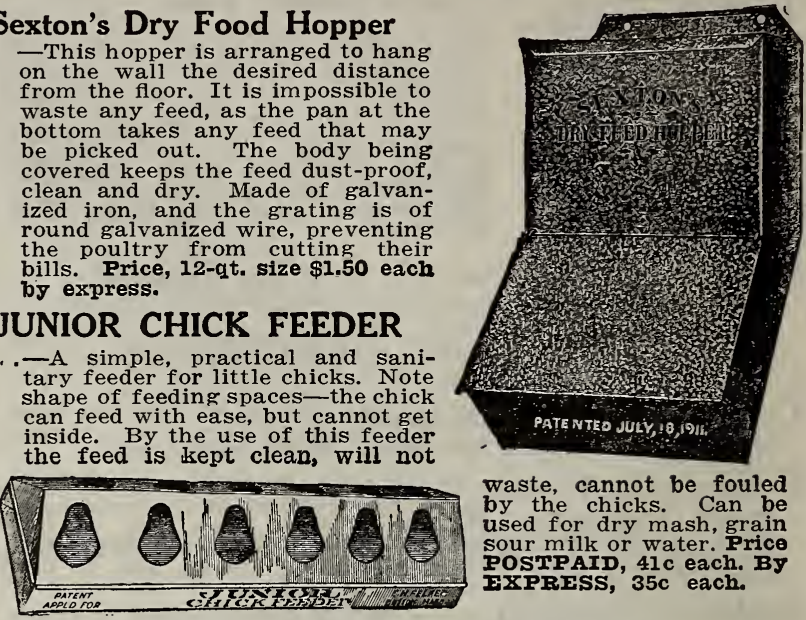

waste, cannot be fouled by the chicks. Can be used for dry mash, grain POSTPAID, $41 \mathrm{c}$ each. BY IXPRISS, 35c each.

Grit and Shell Box ${ }^{\text {This }}$ box is manufactured iron and contains three compartments for food shells or grit. It can be hung up against the wall at any height desired, and is a thoroughly first-class article, practically indestructible, and will last a lifetime. It is the best self-feeding "food hopper" on the market. By the use of these self-feeding boxes practically every particle of grit, oyster shells, bone, meal, forcing food, grain, scraps and other materials supplied will be properly used, preventing all waste, and thus increasing the profits. PRICE POSTPAID, $85 \mathrm{cts}$. each.
PRICE BY EXPRESS, $75 \mathrm{cts}$. each; $\$ 7.00$ per doz.

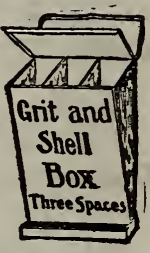

Standard Dry Food Hopper These Standard Dry Food

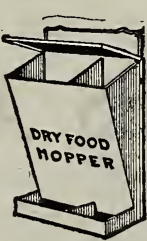
similar to the Shell and Grit Box, but larger. It is a practical labor and food saving device for feeding dry oin food either whole or ground. They have mixture, holding about six quarts, and the smaller one for beef scraps, holding about three quarts. Those who are interested in dry feeding and desire to economize on the cost of grain and beef scraps cannot afford to be without the Dry Food BY FXPRESS, \$1.00 each; \$10.00 per dozen.

\section{One-Two-Three Feeder For feeding}

Scraps, Grit, Oyster Shells, Charcoal or any poultry feed. The separator can be arranged so as you can have one, two or three compartments. When used for one kind of put separator in one end; when used for thre:? kinds, say scraps, shell and grit, put separator in the middle and you have three
compartments. PRICE POSTPAID, small compartments. PRICE POSTPAID, smal PRESS, small size \$1.00; large size \$1.25.
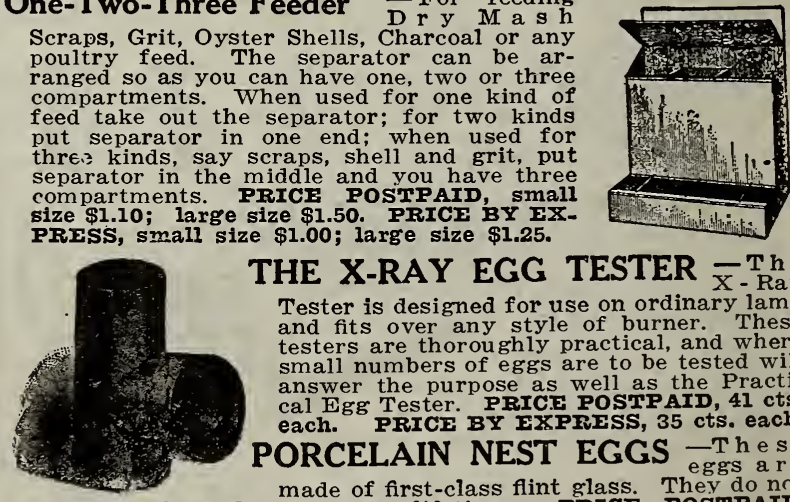

THE X-RAY EGG TESTER $\bar{x}-\mathrm{Th}$ e

Tester is designed for use on ordinary lamp and fits over any style of burner. These testers are thoroughly practical, and where small numbers of eggs are to be tested will answer the purpose as well as the Practical Egg Tester. PRIC.E POSTPAID, $41 \mathrm{cts}$. PORCELAIN NEST EGGS -Th e se

made of first-class flint glass. They do nnt break easily and will last a lifetime. PRICE, POSTPAID

$35 \mathrm{cts}$. per doz. LICE KILLING NEST EGGS -A lice destroyer and nem corner of the nest or under nesting materials, and they will keep the nest sweet and clean. PRICE POS. each; $50 \mathrm{cts}$. per $20 \mathrm{ct}$ 


\section{Champion}

\section{Leg Bands}

fecive per-

fect satisfaction. They are nearanteed to stay on. This band is made in in one piece, in two sizes, adjustable to fit any fowl. It is made of aluminum, large size for Asiatic class and turkeys; small size for Plymouth Rocks and smaller breeds. PRICE, 12 for 15
cts.; 25 for $30 \mathrm{cts}$; 50 for $50 \mathrm{cts.;} 100,75 \mathrm{cts}$. POSTPAID.

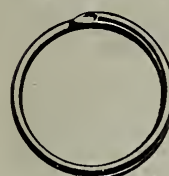
Celluloid Leg Bands -Made in five colorsBlue, Red and Yellow. Five sizes-Baby Chick, Pediterranean and Asiatic. Pigeon, American, Mediterranean and Asiatic. PRICE, doz. 20 cts.; 25 for 35 cts.; 50 for 65 cts.; 100, \$1.00.

Philadelphia Poultry Marker - This marker one for chicks and one for adult fowls. The sizes of holes punched are shown by the black dots printed at the side of this marker. The size made for adult fowls is too large for proper use on new
PRICE, each, 30 cts. POSTPAID.

Perfect Poultry Punch - This punch is so simple in

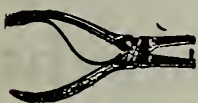
peal to all as a pran that it will ar peal to all as a practical tool. Makes mutilate the ceb, as do many ohe not mutilate the web, as do many cheaper
punches. These punches are made punches. These punches are made

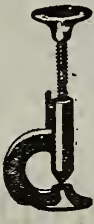
Price by Express, 50 cts. each.

Shipping Coops FOR FANCY POUITRY.-These coops are is a closed coop made of light lumber

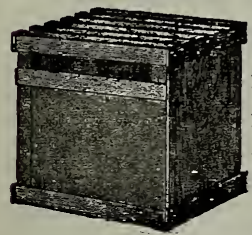
ing front and back under slatted top so as to give the fowls plenty of fresh air when shipping. They are made in 3 sizes, as follows. Shipped knocked down.

12 inches long by 18 inches wide by 18 inches high, 1 bird size, $40 \mathrm{cts}$. each ; $\$ 4.25$ per doz. 18 inches long by 18 inches wide by 18 inches high, 2 bird size, 45 cts. each; $\$ 4.75$ per doz. 18 inches long by 21 inches wide by 21 inches high, 3 bird size, $50 \mathrm{cts}$. each; $\$ 5.50$ per doz. high, 3 bird size,
BY ExPEFs.

Blackhawk Grinding Mill -A most useful and substantial as for farm and family use. By the use of this machine

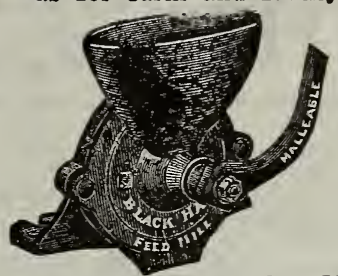
you can always have fresh Graham
Meal, as well as corn meal for the Meal, as well as corn meal for the cleaning, and is easily adjusted for fine or coarse grinding. Is adapted for grinding all kinds of grain and seeds, such as wheat, corn, rye, kafflr corn, sunflower seed, etc., but cannot be used for bones or shells. PRICE, $\$ 3.50$.

Family Grist Mill -Made especialham Flour, Rice, corn Meal, Coffee Spices, etc., for table use. It can also be adjusted for merely cracking the grain if desired. The grinding surfaces are very hard and ground off perfectly true on emery wheels. The shaft is steel. Diameter of hand wheel 20 inches. Weight,
29 lbs. Capacity, $1 \mathrm{lb}$. in 2 minutes. PRICE, $\$ 6.00$ each.

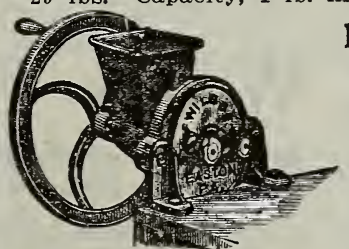
try man. Price, \$6.00.

Mann's Green Bone Cutters - W e confimend these bone cutters, for we are certain that there is no better green bone cutter manufactured. Green cut bone is one of the best foods for egg production. No. 5-B, \$12.50; No. 7, on stand, $\$ 18.50$.
Dry Bone and Shell Mill

For grinding dry bones, oyster shells, charcoal and coarse grain of the handiest appliances in use, and is well made. The hopper is four inches wide and $4 \frac{1 / 2}{2}$ inches long, with a balance wheel 20 ins. low price at which low price at which

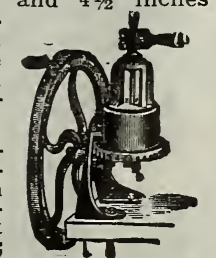

\section{EXTRAS FOR STANDARD CYPHERS INCUBATORS AND BROODERS}

When ordering extras for either incubator or brooder, be sure and state size and style of machine; also the year manufactured. We carry the following in stock and can forward promptly:

Incubator Thermometers -The best incubator or brooder the thermometer used therein is accurate. Hundreds of hatches in incubators fail because of inferior thermometers, and large numbers of chickens are killed in

brooders owing to defective or

worthless thermometers. The ther-

mometer here listed is thoroughly

75 cts. POSTPAID.

Brooder Thermometers -Each, POSTPAID, 75 cts.

Incubator Hygrometers - Should be used by one who runs moisture accurately, overcoming the trouble so many have of chickens "dead in the shell." \$2.00 each, POS'TPAID.

CONNECTING EODS. For Nos. $0,1,2$, or 3 incubator, $50 \mathrm{cts}$. each postpald.

WIRF FANGER YOR INCUBATOR THFRMOMPTER (state size of incubator), 30 cts. each postpaid.

IAMPS with burner and wick complete for No. 0 incubator, $\$ 1.28$ postpaid; by express, $\$ 1.20$ each. For No. 1 incubator, $\$ 1.40$ postpaid; by express, $\$ 1.30$ each. For No

IAMP BOWIS without burner for No. 0 incubator, 88 cts. postpaid; by express, 80 cts. each. For Nos. 1, 2 and 3 incubators, $\$ 1.10$ postpaid; by express, $\$ 1.00$ each.

IANP BURNIRS. For No. 0 incubator, 46 cts. postpald; by express, 40 cts. each. For No. 1 incubator, $60 \mathrm{cts}$. postpaid; by express, 50 cts. each. For Nos. 2 and 3 incubator, 75 cts. postipaid; by express, 65 cts. each.

IIN DISC AND WIRE (state size of incubator), 25 cts. each,

nostpald. postpaid. For Nos. 2 and 3 incubators, 30 cts. per doz. postpaid. BRODDFR IAMP complete with burner and wick for 1909 to 1918 brooder, $\$ 1.38$ postpaid; by express, $\$ 1.30$ each.

CONNFCTING ROD FOR ADAPTABIF HOVFR, $35 \mathrm{cts.} \mathrm{each}$ postpaia.

\section{CYPHERS STANDARD INCUBATORS AND BROODERS}

We are the authorized agents for Cyphers' Fire-Proofed Incubators and Brooders and handle them in large quantities, so that we can sell them at exactly factory prices, free on board cars, Richmond, Va., as follows:

PRICES OF CYPHFRS' SHLF-REGUIATING FIRE-PROOFED No. INCUBATORS

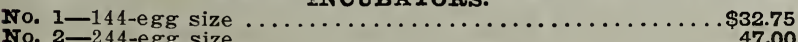

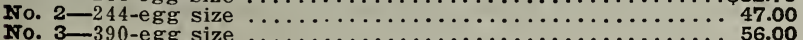

Cyphers' Portable Hover. . . $\ldots \ldots \ldots \ldots \ldots \ldots \ldots \ldots \ldots 14.00$

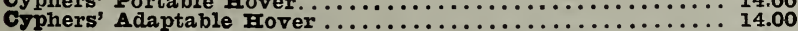

\section{PRICES OF CYPEERS' SEIF-REGUIATING FIRE-PROOFID BROODERS.}

Style A-Outdoor, Self-Regulation. Three Apartment Combination Brooder and Colony House; size $32 \times 32$ inches.. $\$ 23.00$ Style B.-Outdoor (formerly Style A) Self-Regulating. Three Apartment Brooder and Colony House; size $32 \times 64$ ins. . 34.00 PRATRIF BROODFR. A most successful, convenient and econimocal indoor brooding device for small flocks. Suitable for all-year-round use in any well lighted room or apartment 


\section{HYACINTHS}

The First Flowers of Importance to Bloom in the Spring. Produce Beautiful Spikes of Bloom, Strikingly Attractive in Their Richness and Variety of Color. :: :: :: ::

CUITURE IN POTS-Use any good rich soil, mixed with a little sand, potting so as to leave the top of bulb even with the soil. For a single plant use a 4 or 5 -inch pot; but the effect will be prettier if three, six or as many as a dozen are planted
together in a larger size pot, and still more effective if all are of one color. The soil should be pressed firmly around the bulbs, together in a larger size pot, and still more effective if all are of one color. The soil should be pressed firmly around the bulbs, watering once about every ten days, enough to keep the soil moist.

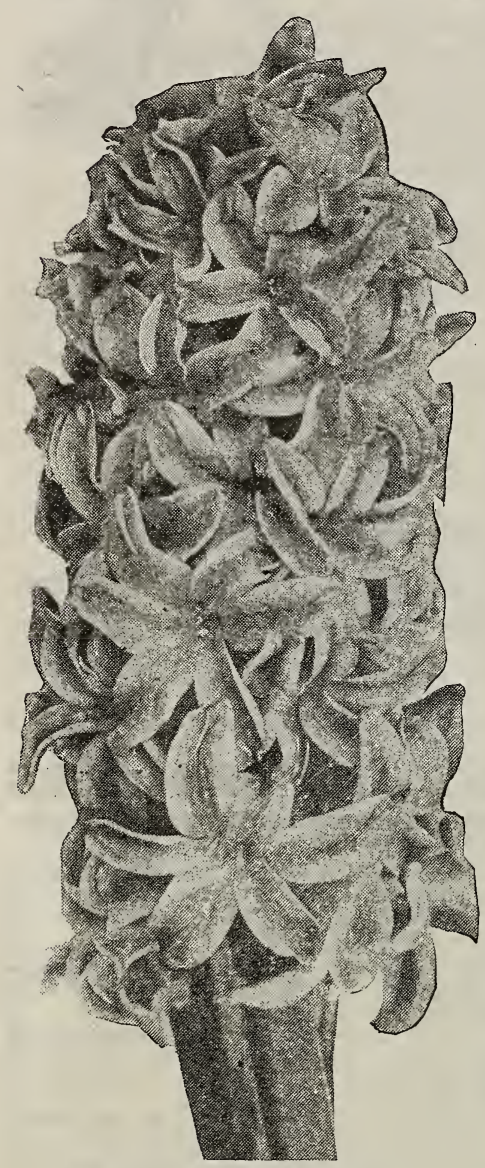

Exhibition Single Hyacinth Ia Grandesse.

A still better plan is to sink the pot in the earth about six inches, covering with soil, choosing some position where they will not get too much water For a succession of bloom, bring the first out about December 1st, and every two weeks thereafter until February 1st. The room in which they are to flower should be only moderately warm, and when they begin to bloom, give plenty of water, and as much fresh air as possible. Too much heat has a tendency to dry up the flower and greatly decrease the blooming period.

CUITURE IN OPEN GROUND.-Any good garden soil will suit Hyacinths, and the depths at which they are planted should be determined by the character of the soil. If clay or very heavy, bulbs should not be covered more than three inches; if light, from four to six inches. They should be protected with manure, leaves or coarse litter to keep them from freezing.

\section{Wood's Exhibition Single Hyacinths}

A Selection of the Best Hyacinths in Cultivation - Single Hyacinths Give Larger Flowers and Make Larger Spikes Than Double Hyacinths.

15 cts. each; $\$ 1.70$ per doz.; $\$ 3.25$ per 25 ; $\$ 11.50$ per 100 , posit-

paid. By express, $\$ 1.60$ per doz.; $\$ 3.00$ for $25 ; \$ 11.00$ per 100 .

\section{SINGLE WHITE}

Alba Superbissima. - A very fine white, tall spike.

Albertine--Pure white, fine for forcing.

Grandeur a IMerveille. - Blush white; very large.

Grand Vedette.-Pure white, very large bells; early.

Ia Grandesse-Extra fine; pure white.

I'Innocence-Tall spike; pure white; good for forcing.

Mad. Van der Hoop-Pure white, large bells. Very early and one of the best whites for forcing.

Irt. Blanc.-Fine pure white, large spike.

Snowball.-Pure snow-white; fine, large bells; early.

voltaire.-Pale Waxy blush.

\section{SINGLE BLUE AND PURPLE}

Baron von Thuyll-One of the darkest blue and purple Hyacinths known and of easy culture: bells small and thickly set upon a long stem.

Bleu IMourant.-Splendid violet-blue.

Charles Dickens.-This is of light porcelain color; very pretty.

Czar Peter.-Very large bells, of clearest porcelain blue; beautifully blotched with purple; large truss and easily forced.
Grand Maitre. - Deep porcelain - blue; large truss.

King of the Blues.-Dark Blue; large spike. Ia Peyrouse.-Delicate lavender; an unusually pretty shade.

Marie-Rich purple; enormous truss.

Queen of the Blues. - Clear, sky-blue; fine spike of very large bells.

\section{SINGLE RED AND PINK}

Garibaldi.-Brilliant carmine.

Gen. Pelissier. - Deep crimson; fine truss; early.

Gertrude.-Fine, dark pink; very large bulb. Gigantea. - Fine, light pink; large spike; small bells.

Iord Macaulay. - Deep carmine-pink with white eyes, extra large and compact spike. Norma.-Very large bulb and easily forced in pots and glasses. Vigorous grower, producing very large spikes. Color, delicate fleshcolored pink.

Robert Steiger. - Fine, large, bright, red; popular.

\section{SINGLE YELLOW}

Ida.-Pure yellow; fine spike.

King of the Yellows-Fine, bright yellow. Sonora.-Orange-yellow, tinted rosy-salmon.

Yellow Hammer,-Fine, rich golden yellow.

Collection of one of each of the above $30 \mathrm{kinds}$, $\$ 3.75$, postpaid. By express, $\$ 3.50$.

\section{Select List of Named Hyacinths SEcond SIzE Select List of Named Hyacinths BULBS}

WHE SAME VARIFTIFS AS THE ABOVE

These bulbs, while a little smaller in size than our Exhibition Hyacinths, will be found very satisfactory either for pots or outside They are specially recommended for bedding, producing magnificent spikes, and are far superior to the ordinary Mixed Hyacinths. The varieties bloom about the same time, and all the bulbs of any sort can be depended on to produce the same shade and grow to an equal height, so that in forming combinations contrasting colors can be selected with certainty, and the effect is greatly increased. Prices, all varieties: By mail, each 12 cts.; dozen, $\$ 1.25 ; 25$ for $\$ 2.50$; $\$ 9.00$ per 100, postpaid. By express, dozen, $\$ 1.15$; 25 for $\$ 2.25 ; 100$ for $\$ 8.50$.

FREESIA PURITY -One of the most charming bulbs known for winter flowering and cut flowers. The blooms are grown can be readily brought into bloom by Christmas. Iarge Bulbs, 3 for 10 cts.; dozen, 35 cts.; 100, \$2.50. 


\section{WOOD'S EXHIBITION DOUBLE HYACINTHS}

This List Embraces the Very Finest Double Varieties in Cultivation.

15 cts. each, $\$ 1.70$ per dozen, $\$ 3.25$ for $25, \$ 12.00$ per 100 , postpald.

By express, $\$ 1.60$ per dozen, $\$ 3.00$ for $25, \$ 11.00$ per 100 .

\section{DOUBLE WHITE}

Ia Tour d'Auvergne.-Pure white and the earliest double white; valuable for house-growing.

Ia Virginite.-Very large spike; creamy white.

Prince of Waterloo. - White, rosy center; large spike and large bells.

Boyal Bouquet.-Pure white; flowers borne on long stems.

\section{DOUBLE RED AND PINK}

Bouquet Tendre (waterloo).-Very fine dark red; good bloomer. Bouquet Royal.-Bells borne on long stems; color, salmon-pink, red center; very attractive.

Grootvorst.-Peach-blossom pink; good truss.

Iord wellington.-Extra fine blush pink; immense bells, and very early.

\section{DOUBLE BLUE}

Bloksberg.-Light blue, large bells, of a beautifully marbled appearance; it is one of the best double blues early.

Garrlck.-Azure-blue; large, compact spike.

Van Sperk. - Bright lavender-blue; very compact spike, with extra large bells.

Rembrandt.-Dark porcelain-blue; splendid spike; late.

\section{DOUBLE YELLOW}

Bouquet Orange.-Reddish yellow; small spike.

Goethe. - Light yellow, vigorous grower, and one of the best double yellows.

Minerva.-Fine orange-yellow, extra large flower.

COIIFCTION OF ONE OF FACH OF ABOVE FIFTEEN IEINDS $\$ 2.00$, POSTPAID. BY EXPRESS, $\$ 1.85$.

\section{Wood's Superior Hyacinths, in Separate Colors}

WOOD'S SUPERIOR FYACINTHS in separate colors can be sold at considerably less price than where it is necessary to keep and name each individual bulb separately. These bulbs are all good-sized flowering bulbs, much larger than the ordinary mixed Hyacinths, and give excellent satisfaction for general forcing, for cut flowers, or outdoor garden blooming in beds or borders.

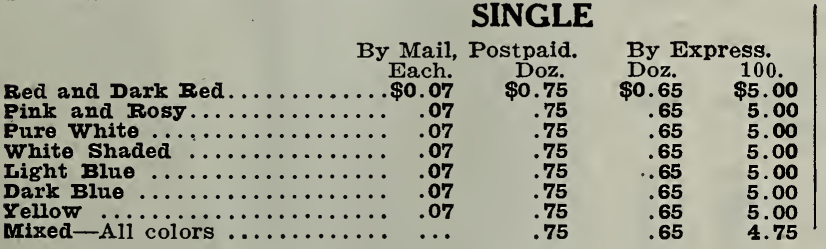

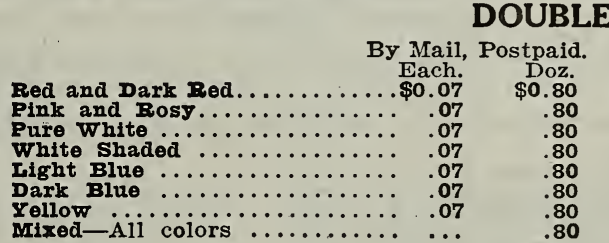

By Express. $\begin{array}{lr}\text { Doz. } & 100 \\ \$ 0.70 & \$ 5.25\end{array}$ $.70 \quad 5.25$ $.70 \quad 5.25$ $70 \quad 5.25$ 5.25 .70

\section{Miniature, or Dutch Roman Hyacinths}

Excellent for growing in pots, pans or boxes, blooming freely and early. May be planted close together in pots or pans, or in beds in open ground. We offer choice named varieties as follows:

Grandeur a Marveille.-Blush white. La Grandesse.-Pure white.

Gertrude.-Pink.

Baron von Thuyll.-Dark blue.

Queen of the Blues.-Light blue.

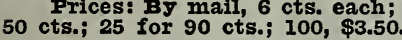

\section{Roman Hyacinths}

The flowers, while smaller than those of the Dutch Hyacinths, are borne in much greater abundance, each producing about six graceful spikes of bloom which makes it a most valuable sort for cutting. They can be forced very easily, and if planted early and brought into the house at intervals of about two weeks, will yield a succession of blooms from Christmas to Easter. The Blue and Rose sorts flower about two weeks later than the White, and we especial :ecommend them with the White Italian ior outdoor planting. By Mail, Postpaid. By Express. Whito Mammoth-13 to 15 centimeter........\$0.15 $\underset{\$ 1.60}{\$ \$ 1.50} \$ 11.00$ White, Iarge-12 to 13 centimeter............12 $\$ 1.60 \quad \$ 1.50 \quad \$ 11.00$

\section{CALLA LILIES}

Well-known house plants of great popularity. Of very easy culture, their one necessity being plenty of water. Our bulbs are large California dry roots, which are best for forcing, producing blooms much more abundantly than those usually grown in the house.

Mammoth Roots. $-30 \mathrm{cts}$. each; $\$ 3.00$ per doz.

First Size Roots.-20 cts. each; $\$ 2.00$ per doz.

\section{LILIUM CANDIDUM}

\section{ANNUNCIATION, MADONNA OR ST. JOSEPH'S IIIY}

Ar old favorite garden Lily, with snow-white, fragrant blossoms. It is $20 \mathrm{cts}$. each; $\$ 2.00$ per doz., postpaid. By express, 15 cts. each; $\$ 1.50$ per duz.

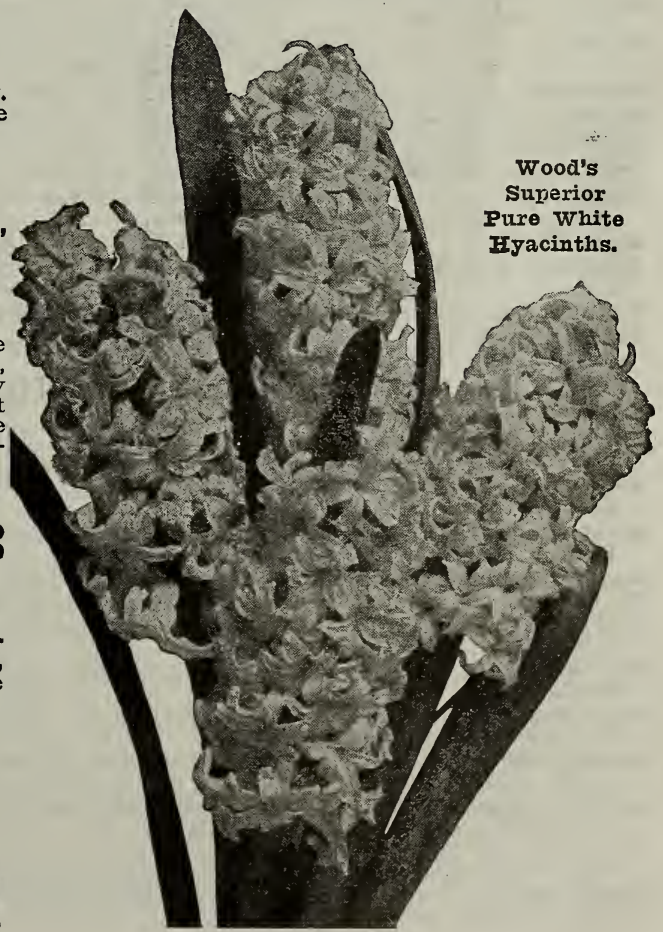




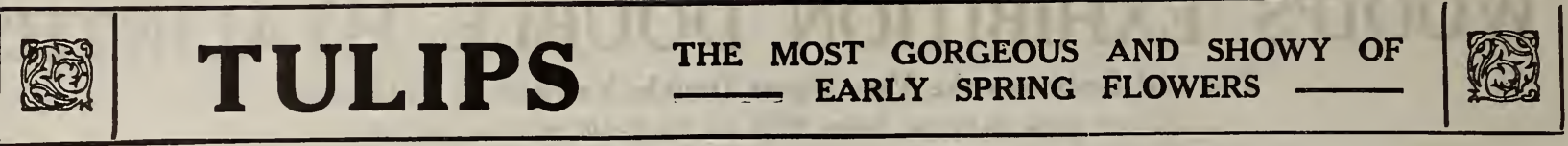

\section{TULIPS FOR CUT FLOWERS}

Tulips make one of the best, brightest and most attractive and satisfactory flowers for the table that can be used. They will also last as long or longer than any cut flowers which are used for decorations. A bed of assorted Tulips used for this purpose will furnish a continuous feast for weeks during

our collections embrace the best sorts, and we have indicated their earliness of flowering by letters. Those marked "A" are the earliest flowers; "B" next, etc. Height in inches is indicated by figures.

\section{SELECT NAMED TULIPS (Single Varieties)}

If sent by rsail, add 5 cts. per doz., 25 cts. per 100, for postage.

Artus (B 7).-Fine bright red; excellent for bedding. Fach, 5 cts....\$0.50 Belle Alliance (B 9).-Beautiful dark scarlet, sweet scented; fine for

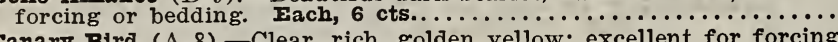
Canary Bird (A 8).-Clear, rich, golden yellow; excellent for forcing or garden. Fach, 6 cts.

Chrysolora (B 9).-Pure yellow; large showy flower; one of the best of this color for bedding, retaining its color until the petals drop.

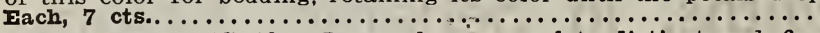
Couleur Cardinal (C 10).-Large, bronze-scarlet; distinct and fine.

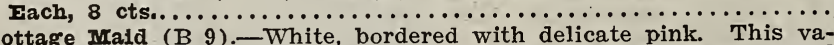
riety is worthy of special mention, being a vigorous grower and riety is the best sorts for bedding and forcing. Fach, 5 cts........ Crimson Ring (B 9).-Fine, showy, bright crimson; large flowers;

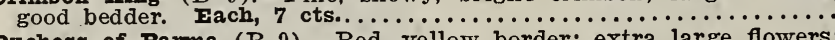
Duchess of Parma (B 9).--Red, yellow border: extra large flowers: one of the most vigorous growers and best bedders in our list Duc $\operatorname{van}$ Thol. - The earliest of all Tulips and very valuable for early forcing.

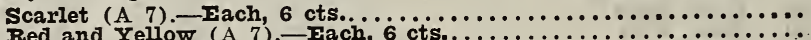

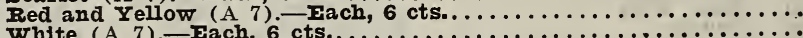
White (A 7). Fach, 6 cts.

Rose (A 7) Fach, 6 cts.

Joost Van Vondel (B 10).-Glossy cherry-red and white; one of the

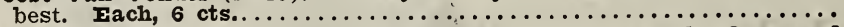
Keizerikroon (B 10).-Deep crimson, with broad orange border; good for forcing; large and effective. Fach, 6 cts....................... Ia Reine (A 8).-Good white, tinged rose; fine for pots. Fach, 6 cts. Pottebakker, Scarlet (A 9).--Bright scarlet; large flower. Fach, 6 cts. Pottebakker, White (A 9).-Pure white, large and showy. Fach, 6c. Proserpine (A 8).-Rich carmine-rose; large and very effective; can

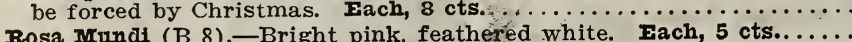
Vermilion Brilliant (B 9).-Splendid, dazzling vermilion; extra fine for pots or massing in beds; very effective. Fach, 7 cts............

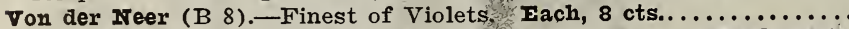

Yellow Prince (B 9).-Large golden yellow; very showy. Each, 6 cts.

\section{DOUBLE VARIETIES}

Couronne d'Or (B 10).-Large, double, rich yellow, with small mixture of red: 4 inches in diameter. This is certainly one of the most at-

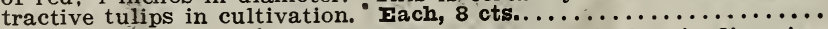

Duke of York (B 10).-White, blood-red center, 4 inches in diameter.

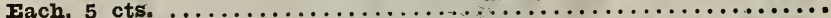

Gloria Solis (A 9).-Rich bronze-crimson with yellow edge; large.

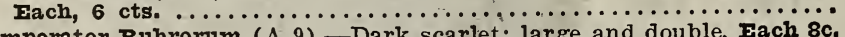
Imperator Rubrorum (A 9).-Dark scarlet; large and double. Fach 8c. Murillo (B 8).-Magnificent blush white, shaded rose, the surest and

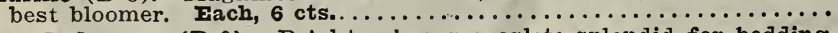

Rex Rubrorum (B 9).-Bright crimson-scarlet; splendid for bedding.

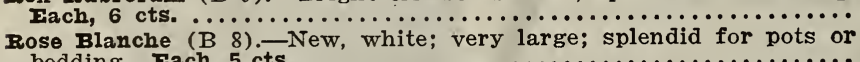
bedding. Fach, 5 cts.........................................

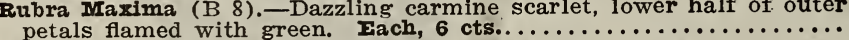
Salvator Rose (B 8).-Deep rosy-pink shaded with blush white; fine

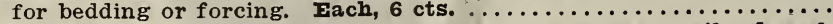
Tournesol (B 9).-Red, yellow edge: sweet scented; easily forced;

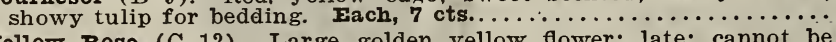

Yellow Rose (C 12).-Large golden yellow flower; late; cannot be

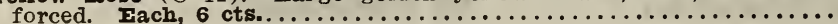

.60

.50 .55 .55

.60 .60 .50 .55 .60 .60 .80 .50 .75 .80 .55 .50 55 .80 .50 .55 .60 .50 .60 .65 .75 .55
100. $\$ 3.50$ 4.50 3.50 3.75 6.00 3.50 3.75 4.50

\subsection{0} 4.50
4.00 4.25 4.00
4.50 4.50 4.50 3.50 4.00 4.50 4.50 6.00 3.75 6.00 6.00 4.00

6.00 3.50

3.75 6.00 3.50 3.75 4.50 3.50 4.50 4.75 6.00 3.75

\section{CUITURE OUT OF DOORS} For bedding, Tulips make one of the most at-
tractive and showy flowers for the garden. The variety of colors and earliness to bloom make them particularly desirable.

In preparing a bed for Tulips, care should be taken to have it so shaped that it will shed water, and the soil should be worked deep and made rich. Plant the bulbs from 3 to 4 inches deep, according to the stiffness of the soil, and from 4 to 6 inches each way. Treat the bed same as outdoor culture for Hyacinths, giving protection with a culturin or two take bulbs up and replant, as they work themselves too deep to bloom well.

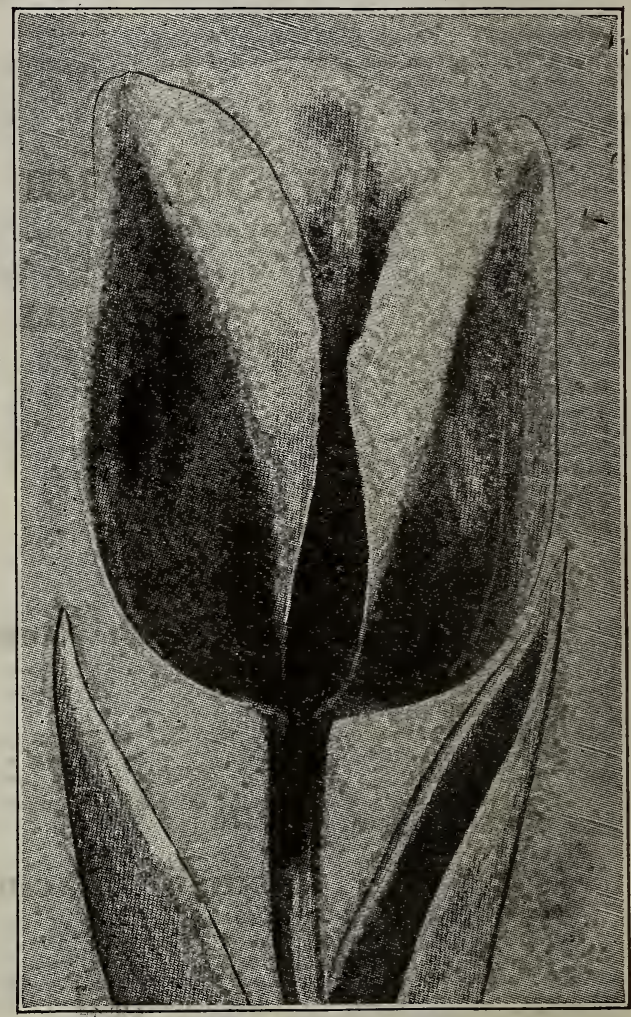

Keizerkroon Tulip.

\section{CHOICE MIXED TULIPS}

WOOD'S SPFCIAI MIXED DOUBIF-Composed entirely of named sorts, proper proportion of bright colors, all blooming together; an unexpostpaid. By express, dozen, 45 cts.; 100, $\$ 3.00$. WOOD'S SPFCIAT MIXED SINGIF.-An extra fine mixture, composed entirely of named sorts of brightest colors, blooming together. $50 \mathrm{cts}$. per doz.; \$3.25 per 100, postpald. By express, 45 cts. per doz.; $\$ 3.00$ per 100 .

\section{PARROT TULIPS}

The flowers of the Parrot Tulip are very peculiarly formed; the petals are all curiously slashed. while the colors are very brilliant and attractive. Chiefly used for outdoor planting and also desirable for baskets, etc. They will stand a little forcing late in the season. Excellent for cutting. FIN MIXID COIORS.-Doz., 50 cts.; 100, \$3.25, postpald. By express, doz. 45 cts.; 100, $\$ 3.00$. 


\section{GIANT DARWIN TULIPS}

These gorgeous new late or May flowering Tulips are very stately and beautiful, producing immense flowers on tall, sturdy stems attaining a height of from two to three feet, and bearing on long stems beautiful globular flowers of remarkably heavy on long stems beautiful globular fowers of remarkably heavy conceivable tint in rose, heliotrope, claret, maroon, crimson and other rich and rare shades. Unsurpassed for bedding and cutting.

The sorts offered below were selected out of a large collection as being the best and most distinct.

If to be sent by mail, add $5 \mathrm{c}$ per doz., $25 \mathrm{c}$ per 100 , for postage.

Baron de la Tonnaye. - Carmine, pink shading to Each. Doz. 100. bluish; large flower, beautifully shaped; height,

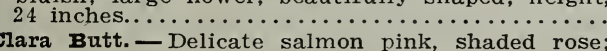
height, 20 inches. ......................... 06 Dream.-Beautiful, delicate lilac; height, 26 inches. $.08 \quad .75 \quad 6.00$ Glow. - Brilliant glowing yermilion, blue center, margined white; height, $2 \%$ inches................ $65 \quad 4.50$

Gretchen-Outside of petals delicate blush; inside soft rose; very pretty; height, 22 inches..........06 $\quad .50 \quad 3.75$ IMadam Irrelage. - Purplish rose, margined with blush pink, white base; very large flower; height,

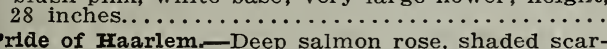

Pride of Haarlem.-Deep salmon rose, shaded scarlet; immense flowers; height, 26 inches..........

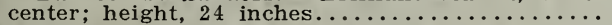

The Sultan,-Rich, glossy maroon, almost black;

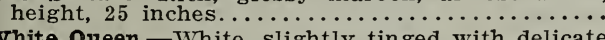

White Queen.-White, slightly tinged with delicate pink; height, 24 inches....................06 $50 \quad 3.75$

WOOD'S SPFCIAI MIXED DARWIN TUIIPS-Composed mostly of named sorts, and contains a great variety of all colors and shapes. 45 cts. per doz.; $\$ 3.00$ per 100

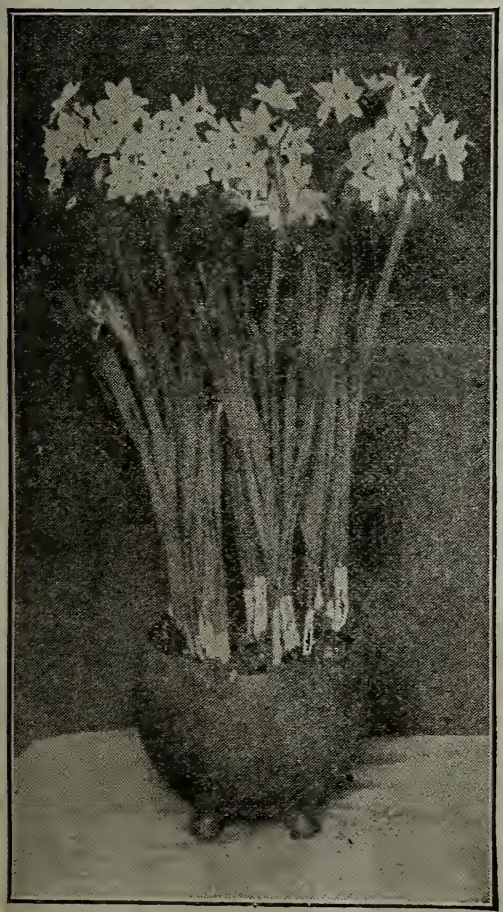

Giant White Narcissus Growing in Iibre

\section{GIANT WHITE NARCISSUS}

\section{The Most Satisfactory Flower That Can Be Grown in the House for Winter Blooming}

They will bloom in water and rocks from six to eight weeks from time of planting, and are superior to Chinese Lilies or any other Narcissus for growing in water. The flowers are larger, more attractive in color and very fragrant. A very unique. simple and novel way to grow this variety of Narcissus is to place six or eight bulbs in a shallow glass or china bowl with water; support the bulbs with pebbles or gravel as you would the Chinese Lily, and place the bowl in the dark until the roots have started, when you should bring them to the light. The water requires chnnging occasionally to keep it pure. Planted any time in September or October, can be easily brought into flower by Christmas. Fach, $8 \mathrm{cts}$.; 6 for 40 cts.; dozen, 75 cts.; 100, \$5.00, postpaid.

\section{RISING SUN NARCISSUS}

This is a yellow Narcissus exactly like the Giant White, except the flowers are a rich yellow instead of white and a little later in blooming than the Giant Whites. Exccllent
for growing in water and rocks, and when grown this way will bloom in from eight to ten weeks from the time they are planted. Plant six or eight bulbs in a china or glass bowl and give the same treatment as Giant Whites. Our stock of these is limited, so we advise our customers to order early. Iarge bulbs, each, 8 cts.; 6 for $40 \mathrm{cts}$.; dozen, $75 \mathrm{cts}$. By express, 65 cts. per dozen; $\$ 5.00$ per 100.

\section{DOUBLE SACRED LILY (Roman Narcissus)}

To be grown in water and rocks the same as the Chinese Sacred Lily. The flowers are white with double yellow center, and are free bloomers, early anr very fragrant. Fach, 7 cts.; dozen, 70 cts., postpaid. By express, 60 cts. per dozen; $\$ 4.50$ per 100.

BERMUDA BUTTERCUP OXALIS -One of the finest winter-flowering bulbs grown. A single plant, well grown, will flowers of bright-buttercup yellow. They commence blooming in about six weeks, and continue in greatest profusion and uninterruptedly for weeks. Estra large bulbs, 3 for $10 \mathrm{cts} . ;$ dozen, $35 \mathrm{cts}$; 100, $\$ 2.50$.

ANEMONES -Attractive and ornamental plants, bearing large single and double flowers in spring and early summer. They should be very largely planted in beds. The effect and almost invariable free-blooming qualities of these will certainly give satisfaction. Various colors-white, blue, red, etc.

SINGIE IIXED-Doz., 35 cts.; 100, \$2.50. DOUBIE IrIXID-Doz., $\leq 0$ cts.; $100, \$ 3.00$.

Prepared Plant Fibre -The most satisfactory way of growing all spring bulbs for house and table decoration. It is brtter than out drainage. By mail, postpaid, $30 \mathrm{cts}$. pkg.; $45 \mathrm{cts}$. half-peck; 85 cts. peck; $\$ 1.50$ half-bushel; $\$ 2.50$ bushel. By express. 8; cts. pkg.; 35 cts. half-peck; 65 cts. peck; $\$ 1.00$ half-bushel; $\$ 2.00$ bushel. 


\section{NARCISSUS, DAFFODILS AND JONQUILS}

Among early spring flowers these are in the front rank of popularity. Appearing just after winter, they animate our gardens with masses of gold and silver, while their fragrant blossoms in the home are invaluable for decorative purposes.

CUITURE IN POXS.-Treatment same as for tulips in pots. The Polyanthus varieties are the earliest blooming and can be forced as easily as Roman Hyacinths.

there is not a spot where grass will grow in of Narcissus should be grown in clumps and patches in every suitable spot, and bulb, allowing 4 to 5 inches between small sorts and 6 to 8 inches between large varieties. The bulbs will the size of the fill the space, forming a compact mass, and it is then their flowers are produced the most freely. Plant the bulbs about 3 inches deep, according to the size of the bulb. The Polyanthus varieties require slight protection.

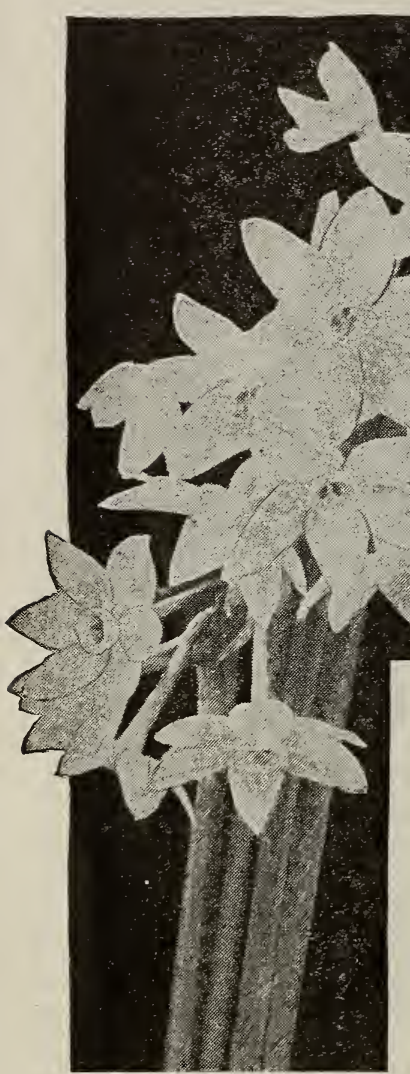

Paper white Grandiflora Narcissus.

\section{POLYANTHUS, or BUNCH-FLOWERED NARCISSUS}

These are generally used for forcing and bear large clusters of delicatelyscented flowers-white, orange, yellow, etc. They are of earliest culture, succeeding well inside or out. Protect with covering of manure or straw if planted outside.

GIANT WHITE.-Splendid for house blooming either in pots or bowls of water. For description and price, see next page.

RISING SUN.-A new Yellow. Narcissus, similar to the Giant white in its desirability for house blooming, both in pots and in gravel-filled water

PAPER WHITE GRANDIFIORA.-These are excellent for growing in water; larger flowers and clusters than Paper White. Planted any time in September, can easily be brought into flower by Christmas. 60 cts. per doz.; $\$ 3.50$ per 100, postpaid. By express, 50 cts. per doz.; $\$ 3.25$ per 100 .

GRAND SOIIFI D'OR.-Rich yellow, with orange cup; a splendid bloomer. 70 cts. per doz., postpaid. By express, 60 cts. per doz.; $\$ 4.50$ per 100.

GIORIOSA SUPFRBA.-Pure white, with rich orange cup. 60 cts. per doz., postpaid. By express, 50 cts. per doz.; \$4.00 per 100.

DoUB should be largely used. as it rarely fails to bloom very freely. 65 cts. per doz. postpaid. By express, 55 cts. per doz.; $\$ 4.00$ per 100.

MIXID POIYATTHUS.-A number of very fine varieties mixed together, producing very pleasing effects in pots or out of doors. 50 cts. per doz., postpaid. By express, 40 cts. per doz.; $\$ 3.50$ per 100 .

\section{DOUBLE FLOWERING NARCISSUS}

Alba Plena Odorata.-A double, pure white variety; with exquisitely scented flowers; excellent for outside planting; cannot be forced. 45 cts. per doz., postpaid. By express, 40 cts. per doz.; $\$ 3.00$ per 100.

Incomparabilis (Eggs and Bacon). Full double flowers of rich yellow and orange; excellent for house and outside planting. $50 \mathrm{cts}$. per doz., postpaid. By express, 45 cts. per doz.; $\$ 3.25$ per 100.

Von Sion-Rich golden yellow, with double trumpet; one of the best forcing sorts and used in immense quantities by florists; an excellent garden sort. 70 cts. per poz. postpaid. By express, 60 cts. per doz.; $100, \$ 3.50$. Double Inixed. All shades and colors. 45 cts. per doz.,

\section{JONQUILS, or SINGLE TRUMPET}

\section{VARIETIES}

Fmpress. - A magnificent large variety, pure white with yellow trumpet, bold and erect, and 7 cts.; 75 cts. per doz., postpaid. By express, 65 cts. per doz.; 100, $\$ 4.50$. Golden Fmperor.-One of the finest Daffodils in cultivation. Flower of richest yellow; trumpet of immense size, the petals of the perianth measuring $3 \frac{1}{2}$ inches across. Each, 7 cts.; 75 cts. per doz., postpaid. By express, 65 cts. per doz.; $\$ 4.50$ per 100 .

Golden Spur_-Splendid large bold flowers of rich yellow color; excellent for pots or garden; early and free flowering. Iach, 7 cts.; 75 cts. per doz. postpaid. By express, 65 cts. per doz.; $\$ 4.50$ per 100.

Cynosure-Light yellow, with rich, broad, yellow top. Beautiful large flowers, $31 / 25$ cts. per flowers, $31 / 2$ inches across; splendid for forcing or outside.

doz., postpaid. By express, $35 \mathrm{cts}$. per doz.; $\$ 2.75$ per 100 . blooming, fine for forcing or outside, and delicately scented. 45 cts. per doz., postpaid. By express, $40 \mathrm{cts}$. per doz.; $\$ 3.00$ per 100.

Poeticus (Pheasant's Eye, or Poet's Narcissus).-Pure white flowers, with orange cup, edged with deep crimson. Beautiful for outside planting; splendid cut flower. Owing to its great beauty this variety has never falled
please. $40 \mathrm{cts}$. per doz., postpaid. By express, 35 cts. per doz.; $\$ 2.75$ per 100.

Princeps.-Deep golden yellow trumpet, with sulphur perianth; large, fine flowers. One of the finest winter flowering varieties; very early. 50 cts. per doz., postpaid. By express, 45 cts. per doz.; $\$ 3.25$ per 100 .

Irumpet Major.-The standard single yellow Daffodil; deep golden yellow; splendid forcing sort and largely used for outside planting. 60 cts. per doz., postpaid. By express, 50 cts. per doz.; $\$ 3.50$ per 100.

Single Mixed.-In all shades, varieties and colors. Made up of named sorts. Excellent for growing in masses for garden decoration and fine for cut
45 cts. per doz., postpaid. By express, 35 cts. per doz.; $\$ 2.50$ per 100.

JONQUILS - Old-fashioned yellow flowers of the Narcissus family, but smaller JONQULL and shorter flowers.

CAMPERNEIT.-Large flowers: an excellent variety for forcing or outside planting. 40 cts. per doz., postpatd. By express, 35 cts. per doz.; $\$ 2.50$ per 100 
From

T. W. WOOD \& SONS

Seed Growers and Merchants 


\section{Standard Grain and Grass Fertilizer}

Analysis: Ammonia, 2 to 3 per cent; Available Phosphoric Acid,

8 to 9 per cent; Potash 2 per cent

This brand is prepared especially for grain and grass crops, and contains the plant foods in proper proportions to start a vigorous contains the plant foods in proper proportions to start a vigorous
growth on which the result of the crop largely. depends, and growth on which the result of the crop largely depends, and
sufficient to feed the crop till maturity. It is quick in its action and lasting in its results. Apply 300 to $400 \mathrm{lbs}$. to the acre when drilled with the seeds; if broadcasted, apply before seeding and harrow in seeds and fertilizer at the same time.

Bag of 200 lbs., $\$ 4.05$; ton, $\$ 39.00$.

\section{Wheat Fertilizer}

Analysis: Ammonia, 1 to 2 per cent; Available Phosphoric Acid, 10 to 11 per cent; Potash, 1 to 2 per cent.

Wheat, like all grain crops, require a liberal amount of phosphoric acid to develop the grain and mature the crop. It also requires sufficient ammonia to produce a quick growth and that rich green color characteristic of a healthy plant, and potash enough to complete the plant foods necessary for a full development. All these plant foods are contained in our Wheat Fertilizer in proper proportions to give the best results at harvest time.

Bag of 200 libs., $\$ 3.55$; ton, $\$ 34.00$.

\section{Vegetable Fertilizer}

Analysis: Ammonia, 3 to 4 per cent; Available Phosphoric Acid, 8 to 10 per cent; Potash, 1 to 2 per cent.

Vegetables of a leafy nature require an ample supply of ammonia to give them that quick growth on which their quality largely depends; others, like beans and peas, demand in addition phosphoric acid to develop and produce their pods and seeds. root crops which require a greater proportion of potash and for which our Standard Potato Fertilizer is better adapted.

Bag of $200 \mathrm{lbs}$., $\$ 4.25$; ton, $\$ 41.00$.

\section{Standard Vegetable Fertilizer}

Analysis: Ammonia, 3 to 4 per cent; Available Phosphoric Acid, 8 to 10 per cent; Potash, 3 to 4 per cent.

An "all-round" fertilizer prepared for use on vegetable crops of very kind, including root crops which require more potash than is contained in our Vegetable Fertilizer described above. The amount of plant food is properly balanced to give good results on all garden crops. An especially good fertilizer for the home garüen. ton, $\$ 46.00$.

\section{Market Grower Fertilizer}

Analysis: Ammonia, 4 to 5 per cent; Available Phosphoric Acid, 8 to 10 per cent; Potash, 1 to 2 per cent.

Market Grower brand is prepared to meet a demand among vegetable growers who want a fertilizer to force a quick growth. This requires a high percentage of ammonia. Market Grower brand is also splendidly adapted for applying to grass and clover

Bag of $200 \mathrm{lbs}$., $\$ 4.70$; ton, $\$ 45.50$.

\section{High-Grade Trucker Fertilizer}

Analysis: Ammonia, 6 to 7 per cent; Available Phosphoric Acid, 8 to 10 per cent; Potash, 1 to 2 per cent.

High-Grade Trucker brand contains an even greater percentage of ammonia than our Market Grower brand and is prepared for those who require this plant food in excess quantity to force the quickest possible growth in truck crops. The amount of ammonia it contains makes it particulariy cutting to force a applying to grass and clover after the first cutting to force a quick healthy growth. On such crops and alfalfa it will pay and later ruttings.

Bag of 200 lbs., $\$ 5.65$; ton, $\$ 55.00$.

\section{Lister's Standard Superphosphate}

Analysis: Ammonia, 3 per cent; Phosphoric Acid, 9 per cent; Soluble Potash, 1 per cent.

A complete fertilizer, containing all the elements of plant food, for any crop as a substitute for stable manure or in combination with manure. It is one of the few fertilizers made of pure animal bone, which accounts for its lasting quality, the effects being bility for vegetable crops, it is fine for grain that is to be followed by grass.

Bag of $200 \mathrm{lbs} ., \$ 4.45$; ton, $\$ 43.00$.

\section{Standard Potato Fertilizer}

r.nalysis: Ammonia, 3 to 4 per cent; Available Phosphoric Acid, 8 to 10 per cent; Potash, 4 to 5 per cent. Although called a potato fertilizer it is equally good for all root crops which demand a liberal supply of potash. It contains start, and will keep up a strong, healthy growth that is so necesmary for the production of large and paying crops. We recomalso a splendid general garden fertilizer.

\section{Sweet Potato Fertilizer}

Analysis: Ammonia, 2 to 3 per cent; Available Phosphoric Acid, 9 to 10 per cent; Potash, 1 to 2 per cent.

A good all-round fertilizer for Irish and sweet potatoes and garden vegetables generally, especially when used in combinacarrots, celery, onions, parsnips, salsify and turnips as well as potatoes, it will increase the crop and produce larger and potatoes, it will increase the crop and produce larger and
smoother roots. Apply 300 to $400 \mathrm{lbs}$. to the acre in drills; if broadcasted, the amount per acre $\$$

\section{Standard Bone Meal}

Analysis: Ammonia, 3 per cent; Bone Phosphate of Lime, 50 per cent; Equivalent to Phosphoric Acid, 22 per cent. Made of pure animal bone, finely ground and thoroughly
steamed to remove the grease. Being finely ground, it is quickly available, and no fertilizer is more lasting in its effects than bone-the beneficial results can be noted for several years after it is applied. There is no crop grown either in the garden or cation of bone; for grain, grass and clover and as a top dressing for hay fields and pastures bone is es
Bag of 200 lbs., $\$ 4.90$; ton, $\$ 47.00$.

\section{Sheep Manure}

In the garden, the hot-bed, the cold-frame, for fruit trees, in flower beds and pots and on the lawn. Sheep Manure will give most excellent results. On the farm it is very effective on corn, mixed with acid phosphate, it will produce largely increased mixed with acid phosphate, it will produce largely increased yields; it is equally good for potatoes if mixed with kainit or
other form of potash. Our Sheep Manure is thoroughly dried and

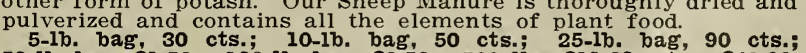
50-1b. bag, $\$ 1.50$; 100-1b. bag, $\$ 2.50$; 500 ibs. $\$ 11.00$; ton, $\$ 42.00$.

\section{Acid Phosphate}

Guaranteed 16 Per Cent Available Phosphoric Acid

Acid Phosphate is recommended for all grain and grass crops, cowpeas, soy or soja beans, and for applying to lands deficient in phosphoric acid. Beneficial results follow the addition of acid phosphate to stable and barnyard manure, all manure being deficient in phosphoric acid but high in ammonia, the mixture giving a better balanced plant food. We handle only 16 per cent acid to the plant food they contain.

Bag of 200 lbs., $\$ 2.65$; ton, $\$ 25.00$.

\section{Nitrate of Soda}

The most readily available form in which nitrogen can be had. Largely used for forcing vegetables, strawberries, etc., for applying to grass fields after each cutting, producing a strong healthy growth and wonderfully increasing the yield. Price, by express $50 \mathrm{lbs}$. \$2.30; $100 \mathrm{lbs}$. \$4.25; $200 \mathrm{lb}$. bag, $\$ 8.00$; 5 bags or more, $\$ 7.75$ per bag. Price fluctuates.

\section{Land Plaster}

Land Plaster has quite a variety of uses. It has the property of combining with the potash in the soil and making it available as plant food. It should be mixed with all stable and barnyard manures, as it combines with the ammonia that might otherwise be lost, and "fixes" it in the form of sulphate of ammonia, in at the form it is taken up by the plant as needed. When it helps to distribute the insecticide more unifnrmly.

Iag of 200 1.:.., \$1.C5; toב, \$1 \$.00. 


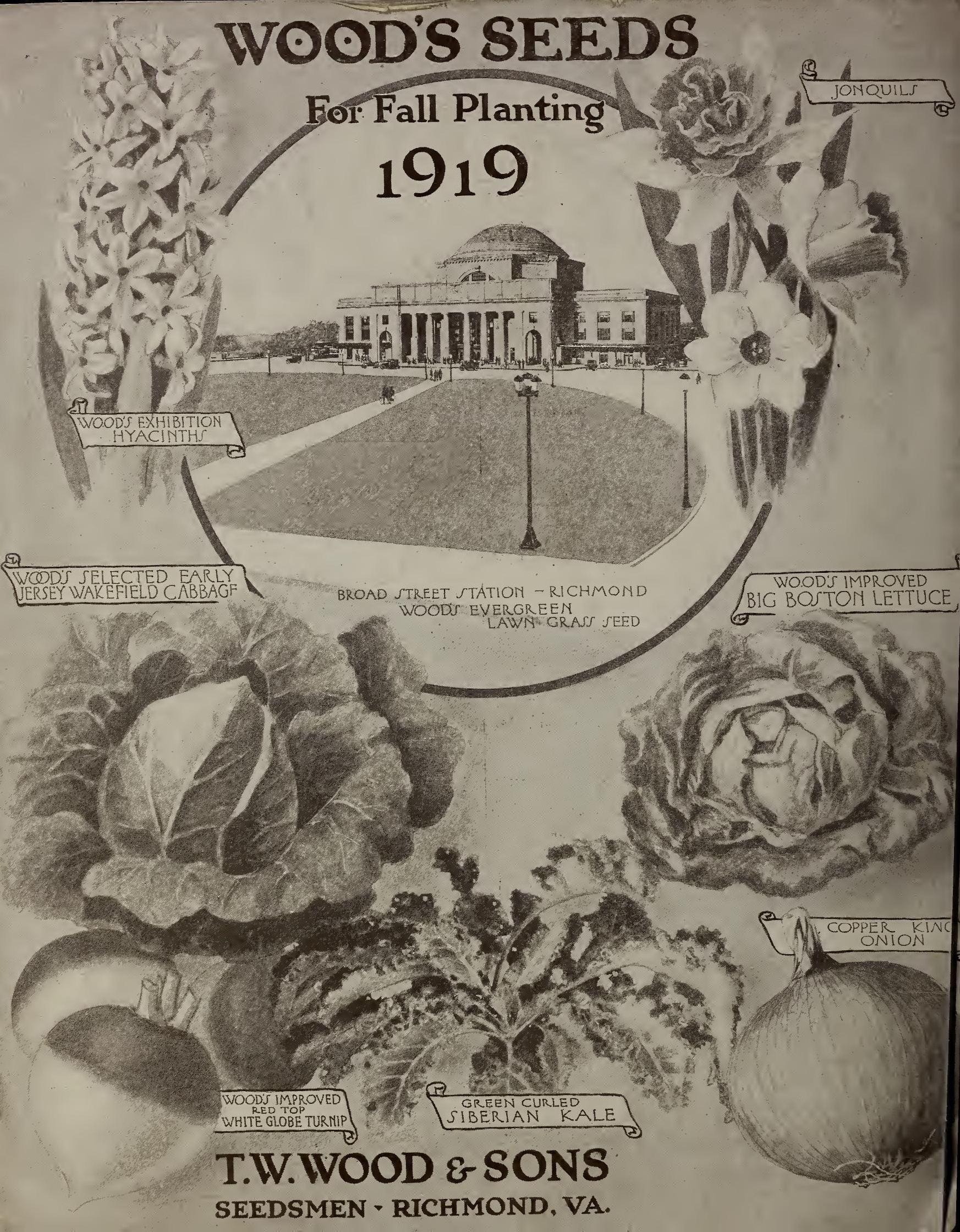

